\title{
Extracellular Delivery of Functional Mitochondria Reverses the Dysfunction of CD4+ T Cells in Aging
}

Colwyn A. Headley ${ }^{1,2}$, Shalini Gautam ${ }^{1}$, Anwari Akhter ${ }^{3}$, Varun Dwivedi ${ }^{1}$, Russell Ault ${ }^{1,2}$, Jordi B. Torrelles $^{3}$, Jonathan Gelfond ${ }^{4}$ and Joanne Turner ${ }^{1}$.

${ }^{1}$ Host Pathogen Interactions Program, Texas Biomedical Research Institute, San Antonio, Texas 78227, USA

${ }^{2}$ Biomedical Sciences Graduate Program, The Ohio State University, Columbus, Ohio 43201, USA.

${ }^{3}$ Population Health Program, Texas Biomedical Research Institute, San Antonio, Texas, 78227, USA

${ }^{4}$ UT-Health San Antonio, Department of Epidemiology \& Biostatistics, San Antonio, Texas 78229, USA

Correspondence: Dr. Joanne Turner; joanneturner@txbiomed.org

Short running title: Mitochondrial Transfer boosts the functionality of CD4+ $\mathrm{T}$ cells from old mice.

Keywords: Aging, Mitochondrial Stress, ROS, CD4+ T cells, Immunometabolism, Oxidative Stress, Immunology, Adaptive Immunity 


\begin{abstract}
Mitochondrial dysfunction alters cellular metabolism, increases oxidative stress, and may be principal to the dysregulated signaling and function of $\mathrm{CD}^{+} \mathrm{T}$ lymphocytes in the elderly. Mitochondria influence adaptive immune responses through glucose and fatty acid metabolism, calcium buffering, and redox signaling. By transferring young mitochondria into $\mathrm{CD} 4^{+} \mathrm{T}$ cells from old mice, we investigated whether aging-associated mitochondrial dysfunction could be abrogated and whether such transfer changed $\mathrm{CD}^{+} \mathrm{T}$ cell function. Our results show that mitochondrial transfer improved the redox status and function of CD4+ $\mathrm{T}$ cells from old mice ex vivo. These findings support the notion that mitochondria can serve as targets of therapeutic intervention in aging.
\end{abstract}




\section{Introduction}

Biological aging positively correlates with acute and chronic infections and diseases that are of increased severity, poor response to vaccines, increased incidence of autoimmunity, and is accompanied by chronic low-grade inflammation [1-4]. $\mathrm{CD}^{+} \mathrm{T}$ cells bridge communication between the innate and adaptive arms of the immune system, and their dysfunction contributes to the aggravation of these aging associated changes. The collective pool of naïve, memory, and effector $\mathrm{CD}^{+}{ }^{+} \mathrm{T}$ cells succumbs to aging-associated perturbations. For example, thymic involution stunts the generation of properly educated naïve $\mathrm{CD}^{+} \mathrm{T}$ cells [5-8]. CD4 ${ }^{+}$memory $\mathrm{T}$ cells generated later in life function at subpar levels compared to those generated in younger years [5, 8-10]. Moreover, the kinetics of $\mathrm{CD}^{+}$effector T cells (i.e. activation and resolution) in aged mice are enervated $[11,12]$.

Mitochondrial activity orchestrates a significant number of $\mathrm{CD} 4^{+} \mathrm{T}$ cell signaling events, including shifts in metabolism and ATP production, intracellular $\mathrm{Ca}^{2+}$ mobilization, gene induction (NFAT, NF-kB, and AP-1), and production of reactive oxygen species (ROS) [13-23]. Perturbations in $\mathrm{T}$ cell intracellular signaling networks are likely central to the collective dysregulation and dysfunction observed in T cells of the elderly [24-27]. Indeed, redox dysregulation due to agingassociated mitochondrial dysfunction might manifest as disturbances in T cell function including, homeostasis, activation, proliferation, and modulation of inflammation.

The optimum levels of ROS necessary for induction of $\mathrm{CD} 4^{+} \mathrm{T}$ cell signaling cascades are mainly generated as byproducts of oxidative phosphorylation (Ox-Phos). Ox-Phos occurs on the inner membrane of mitochondria via the electron transport chain (ETC) [15, 28-31]. Superoxide anions $\left(\mathrm{O}_{2}{ }^{-}\right)$and hydrogen peroxide $\left(\mathrm{H}_{2} \mathrm{O}_{2}\right)$ are the principal mitochondrial ROS (mitoROS) essential for $\mathrm{CD}^{+} \mathrm{T}$ cell redox signaling $[15,23,32]$. Due to its permeability, $\mathrm{H}_{2} \mathrm{O}_{2}$ serves as a secondary messenger molecule [32-35]. For instance, exposed thiol moieties (-SH) on proteins can be 
oxidized by $\mathrm{H}_{2} \mathrm{O}_{2}$, altering protein conformation to favor either increases or decreases in enzymatic activities [36, 37]. Concurrently, mitoROS contribute to the formation of other increasingly destructive ROS. For example, $\mathrm{mtO}_{2}{ }^{\circ}$ - can rapidly react with nitric oxide (NO) to form peroxynitrite (ONOO-), while $\mathrm{H}_{2} \mathrm{O}_{2}$ can react with $\mathrm{mtO}_{2}{ }^{-}-$, transition metals, lipids and proteins found within mitochondria and cells propagating the generation of hydroxyl $(\mathrm{OH} \bullet)$, and peroxyl (ROO•) radicals [29-31, 38-41]. Therefore, shifts in the concerted generation and elimination of mitoROS, as seen in many aged cells, tissues, and organs, contribute to abnormal mitochondrial function which in turn perpetuates redox dysregulation and subsequent T cell dysfunction.

Cellular energy demand is dynamic, and mitochondria must continually fuse and fragment in response to available nutrients and biological stimuli [42-44]. Increases in mitoROS impact mtDNA stability; continual fusion and fission events may also propagate the inter-mitochondrial dissemination of damaged mtDNA [42, 45-49]. Improper translation and assembly of mtDNA encoded proteins, in turn, hinders proper ETC assembly. Often this is associated with increased mitochondrial electron leaks and excess formation of mitoROS, favoring a pro-oxidant intracellular environment [50-52]. In short, mitochondrial dysfunction manifests as quantifiable abnormalities in the assembly of the ETC, mitochondrial membrane potential, excessive production of mitoROS, and abnormal production of ATP via Ox-Phos $[24,50,53]$. These perturbations impact the metabolic fitness and the redox-sensitive signaling pathways of CD4+ $T$ cells $[13,25,50,54-57]$.

Therapeutic interventions that simultaneously improve mitochondrial biogenesis and re-establish the redox equilibrium in aged CD4+ $\mathrm{T}$ cells may abrogate aging-associated $\mathrm{T}$ cell dysfunction [22, $27,58]$. In this proof of concept study, we assessed whether the exogenous delivery of young mitochondria (mitochondria isolated from mouse embryonic fibroblasts) into CD4+ $\mathrm{T}$ cells (mitotransfer) from old mice reestablished cellular redox imbalance positively impacting $C D 4^{+} \mathrm{T}$ cell function. Compared to non-manipulated $\mathrm{CD}^{+} \mathrm{T}$ cells, mitochondrial rejuvenated $\mathrm{CD} 4^{+} \mathrm{T}$ cells 
from old mice had significantly lower levels of mitoROS, enhanced cellular respiration, increased cellular production of cytokines including IL-2, the number of cells expressing $\mathrm{CD}_{2} 5^{+}$, and improved cellular proliferation after activation. These results open the possibility for future translational studies into the immunological and therapeutic implications of directed mito-transfer in aged lymphocytes to re-establish their loss of function.

\section{Methods}

\section{Mice}

Specific pathogen-free C57BL/6 or BALB/c young (2-4 months) and old (18-24 months) mice were obtained from the National Institute on Aging, Charles River Laboratories (Wilmington, MA, USA), and The Jackson Laboratories (Bar Harber, ME, USA). Rag1-KO (B6.129S7-Rag1 1m1Mom/J, 10 weeks old) mice were obtained from The Jackson Laboratories. Mice were housed on individually ventilated cages and fed a standard chow diet, ad libitum, for the duration of this study. All procedures were approved by the Texas Biomedical Institutional Laboratory Animal Care and Use Committee (IACUC) under protocol $1608 \mathrm{MU}$.

\section{Isolation of CD4+ $\mathrm{T}$ cells from mice}

Young and old mice were euthanized by $\mathrm{CO}_{2}$ asphyxiation, and spleens surgically excised. Isolated spleens were individually placed in 6 well plates containing $4 \mathrm{ml}$ of chilled $\left(4^{\circ} \mathrm{C}\right)$ complete DMEM and gently hand homogenized using sterile syringe stoppers. Spleen homogenate was passed through a $70 \mu \mathrm{m}$ microfilter to remove large debris. The resulting single-cell suspensions were centrifuged for $5 \mathrm{~min}$ at $300 \mathrm{xg}$ at $4^{\circ} \mathrm{C}$ and suspended in Gey's lysis buffer ( $8 \mathrm{mM} \mathrm{NH}_{4} \mathrm{Cl}$, $5 \mathrm{mM} \mathrm{KHCO}_{3}$ ) for 1 min to lyse erythrocytes, and then neutralized with an equivalent volume of complete DMEM. Splenocytes were washed and suspended in separation buffer (10 mM DGlucose, $0.5 \mathrm{mM} \mathrm{MgCl}_{2}, 4.5 \mathrm{mM} \mathrm{KCl}, 0.7 \mathrm{mM} \mathrm{Na}_{2} \mathrm{HPO}_{4}, 1.3 \mathrm{mM} \mathrm{NaH}_{2} \mathrm{PO}_{4}, 25 \mathrm{mM} \mathrm{NaHCO}_{3}, 20$ mM HEPES, $5 \mu \mathrm{M}$ DETC, $25 \mu \mathrm{M}$ deferoxamine) containing appropriate antibody-magnetic 
particles for positive selection ( $\alpha$-CD4), or negative selection ( $\alpha-C D 8, \alpha-C D 11 b, \alpha-C D 109$, $\alpha-$ CD24, $\alpha-C D 45, \alpha-C D 49 b, \alpha-L y-6 G, \alpha-\gamma \delta$ TCR, $\alpha-T E R-119)$. The resulting population of CD4+ T cells (85-95\% purity) was used for downstream experiments.

\section{$T$ cell activation}

For experiments requiring $\mathrm{CD}^{+}{ }^{+} \mathrm{T}$ cell activation, cells were incubated in complete DMEM supplemented with phorbol myristate acetate $(P M A)$ and lonomycin $(20 \mathrm{ng} / \mathrm{ml}$ and $1 \mu \mathrm{g} / \mathrm{ml}$ respectively) or $\alpha C D 3 / \alpha C D 28(0.5 \mu \mathrm{g} / \mathrm{ml}$ and $0.05 \mu \mathrm{g} / \mathrm{ml}$ respectively) for specified times.

\section{Quantitation of intracellular ROS}

For flow cytometry-based ROS experiments, CD4 ${ }^{+} \mathrm{T}$ cells were incubated in media containing MitoSOX $(5 \mu \mathrm{M})$ or CellROX $(5 \mu \mathrm{M})$ for 30 mins at $37^{\circ} \mathrm{C}$, to measure mitochondrial and cytosolic ROS, respectively. Cells were washed twice with phosphate-buffered saline (PBS, pH 7.4) and stained with surface antibodies of interest (i.e. $\alpha-C D 3, \alpha-C D 4$, and $\alpha-C D 69 ; 25 \mu \mathrm{g} / \mathrm{ml}$ ) for 20 mins before fixation in $2 \%$ paraformaldehyde. Flow cytometry-based ROS quantification was performed on a BD-LSR II (BD Biosciences, NJ, USA) or Cyan (Beckman Coulter, CA, USA) flow cytometers. Data were analyzed using FlowJo (FlowJo LLC- BD, NJ, USA) and GraphPad Prism 7 (Graphpad Software, CA, USA).

For electron paramagnetic resonance (EPR) based ROS experiments, CD4 ${ }^{+} \mathrm{T}$ cells were probed for $m \mathrm{O}_{2}{ }^{-}$- using Mito-Tempo-H. Briefly, CD4+ $4^{+}$cells were incubated in EPR buffer (10 mM DGlucose, $0.5 \mathrm{mM} \mathrm{MgCl}, 4.5 \mathrm{mM} \mathrm{KCl}, 0.7 \mathrm{mM} \mathrm{Na}_{2} \mathrm{HPO}_{4}, 1.3 \mathrm{mM} \mathrm{NaH}_{2} \mathrm{PO}_{4}, 25 \mathrm{mM} \mathrm{NaHCO}_{3}, 20$ mM HEPES, $5 \mu \mathrm{M}$ DETC, $25 \mu \mathrm{M}$ deferoxamine), containing $100 \mu \mathrm{M}$ Mito-Tempo- $\mathrm{H}$, for $\sim 45 \mathrm{~min}$ at $37^{\circ} \mathrm{C}$. EPR spectra were obtained on the Bruker EMXnano ESR system (Bruker Corporation, MA, USA) using the following parameters: microwave frequency, $9.6 \mathrm{GHz}$; center field, 3430.85 G; modulation amplitude, $6 \mathrm{G}$; microwave power at $25.12 \mathrm{~mW}$; conversion time of $71.12 \mathrm{~ms}$; time 
constant of $20 \mathrm{~ms}$; sweep width of $100 \mathrm{G}$; receiver gain at $1 \times 10^{5}$; and a total number 5 of scans. The Two Dimensional (2-D) spectra were integrated, baseline corrected, and analyzed using spinfit and GraphPad software.

\section{Isolation of mouse embryonic fibroblasts (MEFs)}

MEFs were isolated from day 12-14 E pregnant C57BL/6 mice as previously described [59]. Briefly, mouse embryos were aseptically isolated, minced, and digested in $0.05 \%$ trypsin and crude DNase solution for 30 mins at $37^{\circ} \mathrm{C}, 5 \% \mathrm{CO}_{2}$, in a humidified incubator. Primary MEFs were cultured in sterile T-150 flasks (Corning, NY, USA), in 50:50 F12/DMEM (Corning) supplemented with $10 \%$ FBS, $1 \%$ HEPES, $2 \%$ NEAA, $1 \mathrm{mM}$ sodium pyruvate, $2 \mathrm{mM} \mathrm{L-glutamine,} \mathrm{and} 100 \mu \mathrm{g} / \mathrm{ml}$ primocin. MEFs were sub-passaged as necessary, with MEFs from passages 2-3 being used for all experiments.

\section{Mitochondrial isolation and transfer}

Mitochondria were isolated from MEFs and centrifuged into CD4 ${ }^{+} \mathrm{T}$ cells using a previously published protocol [60]. Briefly, MEFs were homogenized in SHE buffer [250 mM sucrose, $20 \mathrm{mM}$ HEPES, $2 \mathrm{mM}$ EGTA, $10 \mathrm{mM} \mathrm{KCl}, 1.5 \mathrm{mM} \mathrm{MgCl}_{2}$, and $0.1 \%$ defatted bovine serum albumin (BSA)], containing complete Minitab protease inhibitor cocktail (Sigma Alrich, MO, US). The cell homogenate was centrifuged at $800 \times \mathrm{g}$ for $3 \mathrm{~min}$ at $4^{\circ} \mathrm{C}$ to remove cellular debris. The resulting supernatant was recovered and centrifuged at $10,000 \times \mathrm{g}$ for $5 \mathrm{~min}$ to pellet isolated mitochondria. The CD4+ T cells and isolated mitochondria were suspended in $150 \mu \mathrm{L}$ cold PBS in V-bottom 96 well plates, and plates were centrifuged at $1400 \times \mathrm{g}$ for 5 mins at $4{ }^{\circ} \mathrm{C}$. After centrifugation, cells were washed 2-3 times with cold PBS before further experimentation. Independent of mitotransfer, all experimental groups were centrifuged accordingly. 


\section{Determination of cardiolipin content}

Mitochondrial cardiolipin content was determined using a commercially available cardiolipin assay kit (BioVision Inc, CA, USA) per the manufacturer's instructions. Briefly, isolated mitochondria were stained with a cardiolipin specific fluorometric probe 1,1,2,2-tetrakis[4-(2trimethylammonioethoxy)-phenyl]ethene tetrabromide, and quantified against a cardiolipin standard curve.

\section{Transmission electron microscopy}

$\mathrm{CD}^{+} \mathrm{T}$ cells were fixed in PBS containing 4\% glutaraldehyde and $1 \%$ paraformaldehyde for $1 \mathrm{hr}$, after which, cells were rinsed in PBS for 20 min. Samples were fixed in 1\% Zetterqvist's buffered osmium tetroxide for 30 min followed by an alcohol gradient $(70 \%, 95 \%, 100 \%)$ and propylene oxide dehydration (10 min per solution). Samples were blocked in 1:1 propylene oxide/resin for $30 \mathrm{~min}$, and $100 \%$ resin for $30 \mathrm{~min}$ (at $25 \mathrm{psi}$ ). Samples were then polymerized overnight at $85^{\circ} \mathrm{C}$ and stained with $1 \%$ uracil acetate and alkaline lead citrate. Images were captured using a JEM1400 transmission electron microscope (JEOL, MA, USA) at 25,000X magnification, and analyzed using FIJI software [61].

\section{Extracellular flux-based assays (Seahorse)}

Kinetic analysis of cellular glycolysis and oxygen consumption and the rate of ATP production was accomplished through the use of the Extracellular Flux Analyzer XFeg6 (Agilent, CA, USA). Briefly, $2.5 \times 10^{5} \mathrm{CD}^{+} \mathrm{T}$ cells were plated onto poly-D-Lysine pre-coated $(0.1 \mathrm{mg} / \mathrm{ml}) \mathrm{XF}^{\mathrm{e}} 96$ microplates. Using real-time injections, the rates of mitochondrial respiration, glycolysis, and ATP production were measured via oxygen consumption rate (OCR, pmol/min) and extracellular acidification rate (ECAR, $\mathrm{mPh} / \mathrm{min}$ ). 
For mitochondrial stress and ATP production assays, cells were placed in XF assay media supplemented with $5.5 \mathrm{mM}$ glucose, $2 \mathrm{mM} \mathrm{L-glutamine,} \mathrm{and} 1 \mathrm{mM}$ sodium pyruvate. Sequential injections of oligomycin ( $1 \mu \mathrm{M}$; O), carbonyl cyanide-4-(trifluoromethoxy)phenylhydrazine $(1.5 \mu \mathrm{M}$; FCCP), and rotenone: antimycin ( $1 \mu \mathrm{M}, \mathrm{R} / \mathrm{A})$ were used for the mitochondrial stress test, while injections of $\mathrm{O}$ and $\mathrm{R} / \mathrm{A}$ alone were used to determine ATP production rate.

For the glycolysis stress test, cells were assayed in XF media containing L-glutamine, and injections of glucose $(10 \mathrm{mM})$, oligomycin $(1 \mu \mathrm{M})$, and 2-deoxyglucose (50 mM; 2-DG) were used.

For acute $\mathrm{CD}^{+} \mathrm{T}$ cell activation assays, cells were placed in XF assay media supplemented with $5.5 \mathrm{mM}$ glucose, $2 \mathrm{mM}$ L-glutamine, and $1 \mathrm{mM}$ sodium pyruvate. Sequential injections of PMA/lonomycin and 2-DG were used to determine the kinetics of oxygen consumption and extracellular acidification after T cell activation.

\section{Fluorescent glucose uptake assay}

$\mathrm{CD}^{+} \mathrm{T}$ cells were incubated in glucose-free DMEM for 20 min before the addition of complete DMEM supplemented with $50 \mu \mathrm{M}$ 2-deoxy-2-[(7-nitro-2,1,3-benzoxadiazol-4-yl)amino]-D-glucose (2-NBDG), a fluorescent glucose analog, for $30 \mathrm{~min}$. Cells were washed twice in cold PBS, surface stained ( $\alpha-C D 4,25 \mu \mathrm{g} / \mathrm{ml}$ ), fixed in $2 \%$ paraformaldehyde and intracellular levels of 2 NBDG were quantified by flow cytometry.

\section{Cellular ATP levels}

Cellular ATP was determined using a commercially available luminescent ATP detection kit (Abcam) per the manufacturer's instructions. Briefly, $0.5 \times 10^{6} \mathrm{CD} 4^{+} \mathrm{T}$ cells were mixed with the kit's detergent and ATP substrate followed by a 10 min incubation at RT. Samples were read 
using a luminescence microplate reader (Spectra Max M2, Molecular Devices, CA, USA). Absolute ATP concentrations were calculated against an ATP standard curve.

\section{GLUT-1 expression}

Cellular GLUT1 expression was measured by intracellular staining. Briefly, CD4+ ${ }^{+}$cells were fixed and permeabilized using a commercially available kit (BD Biosciences) before intracellular staining with anti-GLUT1 antibody (Abcam, ab195020, 1:100 dilution). CD4+ ${ }^{+}$cells were washed twice and MFI of anti-GLUT1 antibody detected by flow cytometry.

\section{Quantitation of mitochondrial mass and mitochondrial viability/membrane potential}

Cellular mitochondrial mass and potential were determined using commercially available probes MitoView Green (MTV-G Biotium; CA, USA) and Mitotracker Deep Red (MTDR; Life Technologies, CA, USA), respectively. antibody labeled ( $\alpha-C D 4)$ CD4+ $4^{+}$cells were fixed in $2 \%$ paraformaldehyde before MTV-G staining (100 nM) for 30 min at RT or CD4 T cells were stained with MTDR (100 nm) for 20 min before fixation in $2 \%$ paraformaldehyde. The MFI of MTV-G and $\mathrm{MTDR}^{+} \mathrm{CD}^{+} \mathrm{T}$ cells was determined by flow cytometric analysis.

\section{Proteomics}

Cell preparations (with and without added mitochondria) were lysed in a buffer containing 5\% $\mathrm{SDS} / 50 \mathrm{mM}$ triethylammonium bicarbonate (TEAB) in the presence of protease and phosphatase inhibitors (Halt; Thermo Scientific) and nuclease (Pierce ${ }^{\mathrm{TM}}$ Universal Nuclease for Cell Lysis; Thermo Scientific). Aliquots normalized to $65 \mu \mathrm{g}$ protein (EZQ ${ }^{\mathrm{TM}}$ Protein Quantitation Kit; Thermo Scientific) were reduced with tris(2-carboxyethyl) phosphine hydrochloride (TCEP), alkylated in the dark with iodoacetamide, and applied to S-Traps (mini; Protifi) for tryptic digestion (sequencing grade; Promega) in $50 \mathrm{mM}$ TEAB. Peptides were eluted from the S-Traps with $0.2 \%$ formic acid 
in $50 \%$ aqueous acetonitrile and quantified using Pierce ${ }^{\mathrm{TM}}$ Quantitative Fluorometric Peptide Assay (Thermo Scientific).

Data-independent acquisition mass spectrometry was conducted on an Orbitrap Fusion Lumos mass spectrometer (Thermo Scientific). On-line HPLC separation was accomplished with an RSLC NANO HPLC system (Thermo Scientific/Dionex: column, PicoFrit ${ }^{\text {TM }}$ (New Objective; $75 \mu \mathrm{m}$ i.d.) packed to $15 \mathrm{~cm}$ with $\mathrm{C} 18$ adsorbent (Vydac; $218 \mathrm{MS} 5 \mu \mathrm{m}, 300 \AA$ ); mobile phase A, 0.5\% acetic acid (HAc)/0.005\% trifluoroacetic acid (TFA) in water; mobile phase B, 90\% acetonitrile/0.5\% HAc/0.005\% TFA/9.5\% water; gradient 3 to $42 \%$ B in 120 min; flow rate, 0.4 $\mu \mathrm{l} / \mathrm{min}$. A pool was made of all of the samples, and $2-\mu \mathrm{g}$ peptide aliquots were analyzed using gas-phase fractionation and 4- $\mathrm{m} / \mathrm{z}$ windows (120k resolution for precursor scans, 30k for product ion scans, all in the orbitrap) to create a DIA chromatogram library [62] by searching against a panhuman spectral library [63]. Experimental samples were blocked by replicate and randomized within each replicate. Injections of $2 \mu \mathrm{g}$ of peptides were employed. MS data for experimental samples were acquired in the orbitrap using 12- $\mathrm{m} / \mathrm{z}$ windows (staggered; 120k resolution for precursor scans, 30k for product ion scans) and searched against the chromatogram library. Scaffold DIA (v1.3.1; Proteome Software) was used for all DIA data processing.

\section{Western Blot}

$\mathrm{CD}^{+} \mathrm{T}$ cells were lysed by sonication in RIPA buffer containing Minitab protease inhibitors. The total protein quantity per sample was determined by BCA assay. Proteins $(20 \mu \mathrm{g} / \mathrm{sample})$ were resolved on 4-15\% Mini-PROTEAN® TGX ${ }^{\mathrm{TM}}$ Precast Protein Gels (Biorad) and transferred to PVDF membranes. The membranes were incubated overnight with the Total OX-PHOS Rodent WB Antibody Cocktail (Abcam; 1:500) in $1 \%$ milk at $4^{\circ} \mathrm{C}$. The membranes were washed and incubated with mouse IgG kappa-binding protein conjugated to horseradish peroxidase (m-lgGk- 
HRP, $1: 4000$ ) (Santa Cruz technologies) in $5 \%$ milk for $1 \mathrm{~h}$ at $4^{\circ} \mathrm{C}$. The membranes were then stripped and probed for $\beta$-actin levels. Images were captured on a UVP chemstudio 815 system.

\section{Quantitation of intracellular thiols}

Intracellular reduced glutathione levels were determined using commercially available fluorometric thiol probe thiol tracker Violet (Thermo Fisher) and the total GSH Detection Assay Kit (Abcam, MA, USA). CD4 ${ }^{+} \mathrm{T}$ cells were stained with $10 \mu \mathrm{M}$ thiol-tracker for $30 \mathrm{~min}$ at $37^{\circ} \mathrm{C}$. Cells were washed in twice with PBS, stained with surface antibodies of interest (i.e. $\alpha-C D 3, \alpha-C D 4$, and $\alpha-C D 69 ; 25 \mu \mathrm{g} / \mathrm{ml}$ ) for $20 \mathrm{~min}$, fixed in $2 \%$ paraformaldehyde, and data collected by flow cytometry. The total GSH detection assay was performed according to the manufacturer's directions.

\section{Cytokine Detection}

The EliSpot and luminex assays were used to measure cellular production of cytokines. For EliSpot assay, $5.0 \times 10^{4} \mathrm{CD}^{+} \mathrm{T}$ cells were serially diluted onto either $\alpha$-IL-2 or $\alpha$-IFNy sterile coated PVDF 96 well plates (BD Biosciences, NJ, USA). The CD4 ${ }^{+} T$ cells were then activated for 24 or $72 \mathrm{hr}$ in complete DMEM, or in pro-oxidant $\left(100 \mu \mathrm{M} \mathrm{H}_{2} \mathrm{O}_{2}\right)$ or antioxidant (100 $\mu \mathrm{M}$ MnTBAP, or $100 \mu \mathrm{M}$ NAC) conditions. After allotted time points, the Elispot microplates were developed following the manufacture's protocol and analyzed using an ImmunoSpot analyzer (Cellular Technology Limited, OH, USA). Individual spots are representative of individual cytokineproducing cells.

The cytokines IL-2, IFN $\gamma$, IL-4, IL-5, IL-10, IL-17/IL-17A, TNF $\alpha$, CCL5/RANTES, were measured by luminex assay. Briefly, $2.5 \times 10^{\wedge} 5 \mathrm{CD} 4 \mathrm{~T}$ cells were cultured in 96 well plates containng PMA/lonomycin for 24 or $72 \mathrm{~h}$, afterwhich the media was collected and measured for the presence of the aforemention cytokines following the manufacture's protocol. 


\section{Proliferation Assay}

T cell proliferation was determined by the Click-it EdU detection assay [64]. Briefly, $2.5 \times 10^{5} \mathrm{CD}^{+}$

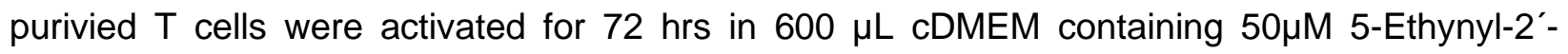
deoxyuridine $(\mathrm{EdU})$ and $\mathrm{\alpha CD} 28(0.05 \mu \mathrm{g} / \mathrm{ml})$, in sterile 48 well plates precoated with $400 \mu \mathrm{L}$ of aCD3 $(0.5 \mu \mathrm{g} / \mathrm{ml}$ in PBS). EdU incorporation into DNA from proliferating cells was detected by a fluorescent bioconjugate and flow cytometry. The assay was performed per the manufacturer's instructions (Thermo Fisher).

\section{Results}

\section{Levels of mitoROS in CD4+ $\mathrm{T}$ cells from old mice decreased after mito-transfer.}

$\mathrm{CD}^{+} \mathrm{T}$ cells isolated from young and old C57BL/6 mice were stimulated with activation mimetics ( $\alpha C D 3 / \alpha C D 28, P M A / I O N O)$ or oxidative stress inducers $\left(\mathrm{H}_{2} \mathrm{O}_{2}\right.$ or Rotenone/Antimycin $\left.A\right)$ to examine levels of mitoROS. CD4 ${ }^{+} \mathrm{T}$ cells from old mice had significantly higher MitoSOX fluorescence compared to $\mathrm{CD}^{+} \mathrm{T}$ cells from young mice both basally and after activation (Fig. 1.A). Initial mitoROS experiments were repeated using young and old BALB/C mice and similar trends were noted; where CD4+ $\mathrm{T}$ cells from old BALB/c mice produced more mitoROS basally and after activation (Supp. Fig. 1.A). To corroborate the flow cytometry-based data, EPR based detection of Mito-TEMPO• in CD4+ $\mathrm{T}$ cells from C57BL/6 young and old mice was used. $\mathrm{CD}^{+}{ }^{\mathrm{T}}$ cells from old C57BL/6 mice showed higher Mito-TEMPO• signal intensity compared to $\mathrm{CD}^{+} \mathrm{T}$ cells from young mice (Supp. Fig. 1.B). These data indicate that $\mathrm{CD}^{+} \mathrm{T}$ cells from old mice produce more mitoROS.

Mitochondria sourced from MEFs $\left(5 \times 10^{6}\right.$ cells in a final volume of $\left.300 \mu \mathrm{L}\right)$ that were pre-stained with the viability dye Mitotracker Deep Red (MTDR) were transplanted into CD4+ ${ }^{+}$cells isolated from old mice $\left(25 \mu \mathrm{L}\right.$ of mitochondrial suspension to $1 \times 10^{6} \mathrm{CD} 4^{+} \mathrm{T}$ cells). After mito-transfer, CD4 ${ }^{+}$ 
T cells were probed with MitoSOX, labeled with $\alpha$-CD4, fixed in PFA, and analyzed by flow cytometry. MTDR $\mathrm{CD}^{+} \mathrm{T}$ cells had lower MitoSOX fluorescence, indicative of decreased mitoROS (Fig. 1.B-C). These data suggested that mito-transfer reduced mitoROS in CD4 ${ }^{+} \mathrm{T}$ cells isolated from old mice. Next, we sought to standardize a protocol for mito-transfer to CD4+ ${ }^{+}$cells.

\section{Standardizing mito-transfer to $\mathrm{CD}^{+} \mathrm{T}$ cells from old mice.}

In eukaryotes, the phospholipid cardiolipin is exclusively found in mitochondria [65-68], and in uniform cell cultures the abundance of cardiolipin can accurately reflect the overall mitochondrial content $[65,68,69]$. Our results estimated that approximately $30 \mathrm{nmol}$ of cardiolipin (equivalent to roughly $250 \mu \mathrm{g}$ of extracted protein) is isolated from $1 \times 10^{7} \mathrm{MEF}$ (Fig. 1.D).

To determine the efficiency of mito-transfer to $C D 4^{+} \mathrm{T}$ cells, MEF were stained with MTDR before isolation and transfer. After mito-transfer, $\mathrm{CD}^{+} \mathrm{T}$ cells were analyzed by flow cytometry to quantify shifts in MTDR fluorescence (MFI), indicative of successful transplantation. Both concentrations tested $(1 \mathrm{nmol}$ and $5 \mathrm{nmol}$ ) significantly shifted the MFI of MTDR (Fig. 1.E). $1 \mathrm{nmol}$ cardiolipin increased the MFI by 5 fold, while $5 \mathrm{nmol}$ increased the MFI by 10 fold (Fig. 1.F). Maximum (100\%) transfer efficiency was achieved with $5 \mathrm{nmol}$ concentration of cardiolipin, and this concentration of isolated mitochondria was used for subsequent experiments.

To determine the impact of mito-transfer on the number of mitochondria in recipient $\mathrm{CD} 4^{+} \mathrm{T}$ cells, we performed transmission electron microscopy (TEM). Immediately after mito-transfer, $\mathrm{CD}^{+}{ }^{\mathrm{T}}$ cells from old mice with donor mitochondria, as well as non-manipulated CD4 ${ }^{+} \mathrm{T}$ cells from young and old mice (controls) were fixed and processed for TEM. Black triangles in TEM slices are representative of individual mitochondria (Fig. 1.G-H). When compared to CD4 ${ }^{+} \mathrm{T}$ cells from young mice, the total mitochondrial area (Fig. 1.J) and the number of mitochondria (Fig. 1.K) per $\mathrm{CD}^{+} \mathrm{T}$ cell from old mice trended towards a decrease but was not significantly lower. The \% ratio 
of mitochondrial area to cell area (Fig. 1.L) was significantly lower in CD4 ${ }^{+} \mathrm{T}$ cells from old mice compared to $\mathrm{CD}^{+} \mathrm{T}$ cells from young mice (4.38\% vs. $\left.5.33 \%\right)$. After mito-transfer was performed on $\mathrm{CD}^{+} \mathrm{T}$ cells from old mice, there were significant increases in the total mitochondrial area (from $0.92 \pm 0.06$ to $1.24 \pm 0.06 \mu \mathrm{m}^{2}$ ), number of mitochondria (from $7.03 \pm 0.35$ to $8.46 \pm 0.46$ ), and \% ratio of mitochondria to cell area (from $4.38 \pm 0.24$ to $5.88 \pm 0.28$ ). These data indicate that mitochondria were successfully delivered into $\mathrm{CD}^{+} \mathrm{T}$ cells from old mice.

\section{Increased oxygen consumption and proton leak of $\mathrm{CD4}^{+} \mathrm{T}$ cells from old mice after mito-}

\section{transfer.}

Extracellular flux analysis (mito-stress test) was used to assess the changes in cellular oxygen kinetics (OCR) before and after $\mathrm{CD}^{+} \mathrm{T}$ cells from old mice were subjected to mito-transfer. The $\mathrm{OCR}$ of $\mathrm{CD}^{+} \mathrm{T}$ cells from young mice was also collected as reference (Fig. 2.A). Except for increased proton leak in $\mathrm{CD}^{+} \mathrm{T}$ cells from old mice, there were no other significant differences in the measured OCR parameters of CD4 ${ }^{+}$T cells from young and old mice (Fig. 2.A-D). However, mito-transfer significantly increased the basal, maximal, spare respiratory capacity (Fig. 2.B), proton leak, and non-mitochondrial oxygen consumption rates of CD4+ T cells from old mice (Fig. 2C). After mito-transfer, the OCR of $\mathrm{CD}^{+} \mathrm{T}$ cells from old mice linked to mitochondrial ATP production trended towards an increase but was not significantly different (Fig. 2.C). Additionally, the coupling efficiency of CD4 ${ }^{+} \mathrm{T}$ cells from old mice decreased after mito-transfer (Fig. 2.D). The extracellular acidification rate (ECAR) of $\mathrm{CD}^{+} \mathrm{T}$ cells from old mice was significantly higher than that of $\mathrm{CD}^{+} \mathrm{T}$ cells from young mice, and mito-transfer further enhanced the ECAR of $\mathrm{CD}^{+} \mathrm{T}$ cells from old mice (Supp. Fig. 2.A-B). In summary, mito-transfer increased the rates of Ox-Phos in $\mathrm{CD}^{+} \mathrm{T}$ cells from old mice. 


\section{Increased glycolysis in CD4+ $\mathrm{T}$ cells from old mice after mito-transfer.}

Aerobic glycolysis and mitochondrial respiration ( $\beta$-oxidation) both contribute to cellular ECAR [70]. We delineated the observed changes in ECAR by performing the glycolysis stress test (Fig.

2.E). Basally, $C D 4^{+} \mathrm{T}$ cells from old mice were more glycolytic than $\mathrm{CD} 4^{+} \mathrm{T}$ cells from young mice and had increased non-glycolytic acidification (Fig. 2.F). Mito-transfer further increased glycolysis, non-glycolytic acidification, and the glycolytic capacity of CD4+ $\mathrm{T}$ cells from old mice (Fig 3.F). No significant differences in the glycolytic reserve were observed between CD4+ T cells from young and old mice. However, after mito-transfer, CD4 ${ }^{+} \mathrm{T}$ cells from old mice had significantly lower glycolytic reserves (Fig. 2.F). Similar results were obtained from the glycolytic flux assay (Supp. Fig 2.C-D)

To further examine cellular glycolysis, $\mathrm{CD}^{+}{ }^{+} \mathrm{T}$ cells from the experimental groups were incubated in DMEM containing 2-NDBG. The percent and relative MFIs of 2-NDBG+ cells were quantified to corroborate the results from the glycolysis stress test. CD4 ${ }^{+} \mathrm{T}$ cells from old and young mice had similar percent of 2-NDBG+ populations (Fig. 2G-H). After mito-transfer, the percentage of 2$\mathrm{NDBG}^{+} \mathrm{CD}^{+}{ }^{+} \mathrm{T}$ cells significantly increased. These data suggest that mito-transfer increased the glucose uptake of $\mathrm{CD}^{+} \mathrm{T}$ cells from old mice.

The relative $\mathrm{MFI}$ of $2-\mathrm{NDBG}^{+} \mathrm{CD}^{+} \mathrm{T}$ cells from young mice was significantly higher than that of $\mathrm{CD}^{+} \mathrm{T}$ cells from old mice (Fig. 2.I). Mito-transfer further decreased the MFI of CD4 ${ }^{+} \mathrm{T}$ cells from old mice (Fig. 2.I). The decrease in MFI suggests faster degradation of 2-NDBG, and increased glycolysis $[71,72]$. We additionally assessed the expression of GLUT-1 in CD4+ ${ }^{+}$cells after mitotransfer but observed no significant change (Fig. 2.J-K). Collectively, data from seahorse and flow cytometry-based assays suggest that mito-transfer increased glycolysis in $\mathrm{CD}^{+} \mathrm{T}$ cells from old mice. 


\section{Increased ATP production in $\mathrm{CD}^{+} \mathrm{T}$ cells from old mice after mito-transfer.}

Increased glycolysis and oxygen consumption hinted towards an increase in the synthesis of ATP $[73,74]$. Through the XF ATP rate assay, we determined whether mito-transfer increased ATP synthesis in $\mathrm{CD}^{+} \mathrm{T}$ cells from old mice, and what were the relative contributions of glycolysis and mitochondrial Ox-Phos. Compared to young mice, $\mathrm{CD}^{+}{ }^{+} \mathrm{T}$ cells from old mice showed higher rates of glycolysis-linked ATP production (Fig. 2.L). CD4 $^{+} \mathrm{T}$ cells from young and old mice had comparable rates of mitochondria-linked ATP production (Fig. 2.M). Mito-transfer enhanced both mitochondria and glycolysis linked ATP production rates of $\mathrm{CD}^{+} \mathrm{T}$ cells from old mice, with a roughly $50 \%$ increase in total ATP production (Fig. 2.L-N). We additionally measured the intracellular levels of ATP but noted no significant differences among the groups (Fig. 2.0).

\section{Altered mitochondrial properties of $\mathrm{CD4}^{+} \mathrm{T}$ cells from old mice after mito-transfer.}

Mitochondrial mass, mitochondrial membrane potential, the rate of proton leak, oxygen consumption, and ATP synthesis dynamically influence mitoROS production $[50,51,75]$. We examined how mitochondrial dynamics changed in $\mathrm{CD}^{+} \mathrm{T}$ cells from old mice $4 \mathrm{~h}$ after mitotransfer, and compared these against non-manipulated $\mathrm{CD}^{+} \mathrm{T}$ cells from young and old mice. $\mathrm{CD}^{+} \mathrm{T}$ cells were stained with three different mitochondrial fluorescent probes; MTV-G, a membrane potential insensitive probe (mitochondrial mass), MTDR which is mitochondrial membrane potential sensitive, and the $\mathrm{mtO}_{2}$ - indicator MitoSOX. The relative mitochondrial mass of $\mathrm{CD}^{+} \mathrm{T}$ cells from old mice was significantly lower than that of $\mathrm{CD} 4^{+} \mathrm{T}$ cells from young mice. $4 \mathrm{~h}$ after mito-transfer, $\mathrm{CD} 4^{+} \mathrm{T}$ cells isolated from old mice had significantly lower mitochondrial content than that of untreated controls (Fig. 3.A-B). Furthermore, basal levels of mitoROS in CD4 ${ }^{+}$ T cells from old mice after mito-transfer decreased to comparable levels of mitoROS found in $\mathrm{CD}^{+} \mathrm{T}$ cells from young mice (Fig. 3.E-F). EPR based detection of Mito-TEMPO showed identical results to flow-based analysis; when compared to $\mathrm{CD}^{+}{ }^{+} \mathrm{T}$ cells from old mice, mito- 
transfer significantly decreased Mito-TEMPO signal intensity by $\sim 60 \%$ in $\mathrm{CD}^{+} \mathrm{T}$ cells from old mice (Fig. 3.G-H).

\section{Increased number of ETC related proteins in $C D 4^{+} \mathrm{T}$ cells from old mice after mito-transfer.}

Increased cellular metabolism, paired with decreased mitochondrial mass suggested that mitotransfer induced restructuring of the mitochondrial cristae in CD4 ${ }^{+} \mathrm{T}$ cells from old mice. The noted increase in cellular respiration may demand an increased ETC activity. Therefore, the levels of proteins related to the ETC of $\mathrm{CD}^{+} \mathrm{T}$ cells from old mice before and after mito-transfer were compared using mass spectrometry-based proteomic analysis (Fig. 4.A). Four $\mathrm{h}$ after mitotransfer, $\mathrm{CD}^{+} \mathrm{T}$ cells from old mice showed significant upregulation of proteins related to complexes of the ETC, such as NDUS2, SDHA, COX15, QCR7, ATPK, as well as adenosine nucleotide translocase 1 (ADT-1), a protein related to ATP synthesis and inducible proton leak (Fig. 4.A-B, Table 1.).

We additionally examined the expression of select ETC proteins (NDUFB8, SDHB, UQCRC2, MTCO1, and ATP5A) in CD4 ${ }^{+} \mathrm{T}$ cells at 30 min and $4 \mathrm{~h}$ after mito-transfer, and compared their relative expression against those of $\mathrm{CD}^{+} \mathrm{T}$ cells isolated from young and old mice (Fig. 4.C-E). Compared to $\mathrm{CD}^{+}{ }^{+} \mathrm{T}$ cells from young mice, significantly lower amounts of UQCRC2, a subunit of CIII of the ETC, were detected in $\mathrm{CD}^{+}{ }^{+} \mathrm{T}$ cells isolated from old mice. While the levels of ATP5A, a protein subunit of the ATP synthase machinery, trended towards a decrease in CD4 ${ }^{+} \mathrm{T}$ cells from old mice, it was not statistically significant (Fig. 4.C-D). No other significant differences were noted between the detected ETC proteins of CD4+ ${ }^{+}$cells from young and old mice. Four $\mathrm{h}$ after mito-transfer ATP5A and UQCRC2 were significantly upregulated in CD4+ $T$ cells from old mice (Fig. 4.D-E). These data corroborate the trends seen in the mass spectrometry proteomic analysis (Fig. 4.A-B). 


\section{Improved antioxidant capacity of CD4 ${ }^{+} \mathrm{T}$ cells from old mice after mito-transfer.}

Mito-transfer altered mitochondrial dynamics and significantly decreased basal mitoROS production in $\mathrm{CD}^{+} \mathrm{T}$ cells from old mice. Next, we assessed whether mito-transfer also impacted the antioxidant capacity of $\mathrm{CD}^{+}{ }^{+} \mathrm{T}$ cells from old mice. The expression of antioxidant proteins was detected by LC-MS/MS, and cellular thiol levels quantified by flow cytometry and microplatebased assays. Four $\mathrm{h}$ after mito-transfer, except for glutathione peroxidases 7 \& 8 (GPX7-8), there was a global downregulation of mitochondrial and cytosolic antioxidant proteins in $\mathrm{CD}^{+} \mathrm{T}$ cells from old mice (Fig. 5.A-B, Table 2). Flow cytometry-based detection of thiols showed no significant change in CD4 ${ }^{+} \mathrm{T}$ cells from old mice after mito-transfer (Supp. Fig 4.A). However, after mitogenic stimulation, old $\mathrm{CD} 4^{+} \mathrm{T}$ cells after mito-transfer produced significantly higher levels of GSH at 4, 24, and $72 \mathrm{~h}$ post-activation (Fig. 5.C-E). These data suggest that mito-transfer improved the antioxidant capacity of $\mathrm{CD}^{+} \mathrm{T}$ cells from old mice. We also compared the levels of mitochondrial and cytosolic ROS following activation of $\mathrm{CD}^{+} \mathrm{T}$ cells after mito-transfer. Similar to GSH, MitoROS was significantly increased after $\mathrm{CD}^{+} \mathrm{T}$ cells with mito-transfer were stimulated with PMA/ionomycin (Fig. 5.F-G), with no significant change to cytosolic ROS (Fig. 5.H).

\section{Activation-induced switch from Ox-Phos to aerobic glycolysis is enhanced in CD4+ T cells from old mice after mito-transfer.}

Aerobic glycolysis is the preferred energy configuration of effector CD4+ T cells [20, 76-80]. Since mito-transfer increased basal Ox-Phos in CD4+ $\mathrm{T}$ cells from old mice, we questioned how mitotransfer impacted the ability of $\mathrm{CD}^{+} \mathrm{T}$ cells from old mice to undergo activation-induced switch from Ox-Phos to aerobic glycolysis. The basal OCR of mito-transferred CD4+ ${ }^{+}$cells from old mice was significantly higher than that of non-manipulated $\mathrm{CD}^{+} \mathrm{T}$ cells from old mice (Fig. 6AB), and these data are in agreement with our previous OCR data (mito-stress test Fig. 2.A-B). After acute PMA/IONO injection, the peak OCR values of mito-transferred $\mathrm{CD}^{+}{ }^{+} \mathrm{T}$ cells were significantly higher than those of non-manipulated $\mathrm{CD}^{+} \mathrm{T}$ cells from old mice and remained 
significantly higher through the plateau phase of the activation assay (Fig. 6.B). Mito-transferred $\mathrm{CD}^{+} \mathrm{T}$ cells from old mice had a much steeper OCR decline than non-manipulated $\mathrm{CD} 4^{+} \mathrm{T}$ cells from old mice (Supp Fig. 4). Similar trends were noted for ECAR measurements of mitotransferred $\mathrm{CD}^{+} \mathrm{T}$ cells from old mice (Fig. 6.C-D). Collectively these data suggest that mitotransferred $\mathrm{CD}^{+}{ }^{+} \mathrm{T}$ cells more rapidly switched from Ox-Phos to aerobic glycolysis.

\section{Enhanced surface marker expression on $\mathrm{CD}^{+} \mathrm{T}$ cells from old mice after mito-transfer in response to ex vivo activation.}

To further examine whether mito-transfer would improve T cell activation, the expression of CD69 and CD25, common markers of T cell activation, were determined $24 \mathrm{~h}$ after mitogenic stimulation. We hypothesized that mito-transfer would improve the activation of CD4+ $\mathrm{T}$ cells from old mice in a redox-dependent manner. Therefore we additionally contrasted how the increased presence of antioxidant supplementation or oxidative stress (via supplementation of $\mathrm{NAC}$ or $\mathrm{H}_{2} \mathrm{O}_{2}$, respectively) would impact the activation status of $\mathrm{CD}^{+} \mathrm{T}$ cells from old mice. Mito-transfer increased the number of $\mathrm{CD}^{2} 5^{+} \mathrm{CD}_{69}{ }^{+}$cells by approximately $50 \%$ (Fig. 7.A-B). CD4 ${ }^{+}$T cells from old mice that were activated under $\mathrm{H}_{2} \mathrm{O}_{2}$ induced oxidative stress had a $50 \%$ decrease in $\mathrm{CD}^{2} 5^{+} \mathrm{CD} 69^{+}$cells (Fig. 7.B). The number of $\mathrm{CD}^{2} 5^{+} \mathrm{CD}^{2} 9^{+}$cells after activation of $\mathrm{CD} 4^{+} \mathrm{T}$ cells from old mice in NAC supplemented media was comparable to that of CD4+ ${ }^{+}$cells from old mice after mito-transfer (Fig. 7B). Overall, mito-transfer increased the amount of CD4+ ${ }^{+}$cells from old mice that expressed of $\mathrm{CD}_{2} 5^{+}$(Fig. 7.C) but did not change the number of CD69+ cells after activation (Fig. 7D). Additionally, the supplementation of $\mathrm{NAC}$ and $\mathrm{H}_{2} \mathrm{O}_{2}$ during the activation of $\mathrm{CD}^{+} \mathrm{T}$ cells from old mice confirms that mito-transfer elicited a redox-dependent improvement in T cell function. 


\section{Increased number of IL-2+ CD4+ $\mathrm{T}$ cells, proliferation, after mito-transfer in response to ex vivo activation.}

The increased expression of CD25, a high-affinity IL-2 receptor (IL-2R $\alpha$ ) [81, 82], on CD4+ $\mathrm{T}$ cells after mito-transfer in response to ex vivo activation prompted us to examine whether cellular production of IL-2 improved after mito-transfer in $\mathrm{CD}^{+} \mathrm{T}$ cells from old mice. Previous studies highlighted the involvement of mitoROS, specifically $\mathrm{H}_{2} \mathrm{O}_{2}$, in modulating IL-2 expression in T cells [15]. We compared the production of IL-2 by CD4 ${ }^{+} \mathrm{T}$ cells from old mice with or without mitotransfer and by $\mathrm{CD}^{+} \mathrm{T}$ cells from old mice cultured under pro-oxidant $\left(100 \mu \mathrm{M} \mathrm{H}_{2} \mathrm{O}_{2}\right)$, and $\mathrm{H}_{2} \mathrm{O}_{2}$ scavenging conditions (100 $\mathrm{M} \mathrm{NAC}$, the precursor of glutathione), after $24 \mathrm{~h}$ of mitogenic activation, and then determined the quantity of IL-2 producing cells (IL-2+ spots), and the average IL-2 spot size via EliSpot analysis (Fig. 7.E). Mito-transfer increased the amount of IL-2 $2^{+}$spots (counted as individual spots) by approximately 50\% (Fig. 7.F-G). CD4 ${ }^{+} \mathrm{T}$ cells from old mice cultured in NAC had a 3 fold increase in IL-2 ${ }^{+}$spots (Fig. 7.E-G). CD4 ${ }^{+}$T cells activated in prooxidant conditions (100 uM H $\mathrm{H}_{2} \mathrm{O}_{2}$ for $24 \mathrm{~h}$ ) had $30 \%$ fewer IL-2+ spots (Fig. 7.E, G). The number of IFN $\gamma$ producing cells, a cytokine produced downstream of IL-2, was also increased post-mitotransfer (Supp. Fig. 4.). These data suggest that mito-transfer increased the number of individual $\mathrm{CD}^{+} \mathrm{T}$ cells from old mice that could produce IL-2.

To determine whether the impact of mito-transfer extended beyond IL-2 production or T helper cell lineage, we additionally measured the levels of soluble IL-2 and other cytokines (IFN $\gamma$, TNFa, IL-4, IL-5, IL-10, IL-17) and the chemokine CCL-5/RANTES, in the culture media of activated nonmanipulated and mito-transferred $\mathrm{CD}^{+} \mathrm{T}$ cells at 24 and $72 \mathrm{~h}$ post activation (Fig. 7.H-I). The levels of IL-2 in the media of CD4 ${ }^{+} \mathrm{T}$ cells with mito-transfer were significantly lower than that of non-manipulated CD4 ${ }^{+} \mathrm{T}$ cells from old mice at $24 \mathrm{~h}$ post activation (Fig. 7.H-I). Furthermore, at $24 \mathrm{hr}$ post activation, the media of mito-transferred $\mathrm{CD}^{+} \mathrm{T}$ cells from old mice also contained 
significantly lower levels of cytokines TNFa and IL-4, significantly higher levels of IL-5 and CCL5/RANTES, and comparable levels of IFN $\gamma$, IL-10, and IL-17a. Comparared to media of nonmanipulated $\mathrm{CD}^{+} \mathrm{T}$ cells from old mice, at $72 \mathrm{~h}$ post activation, the media of mito-transferred $\mathrm{CD}^{+} \mathrm{T}$ cells from old mice contained significantly lower levels of cytokines IFN $\gamma$ and IL-4, significantly higher levels of IL-5, IL-10, IL-17a, and CCL-5/RANTES, and comparable levels of IL-2 and TNFa. These data suggest that mito-transfer in old CD4+ $\mathrm{T}$ cells impacts broad cytokine production and extends beyond $24 \mathrm{~h}$ of activation.

Finally, whether the proliferative capacity of $\mathrm{CD}^{+} \mathrm{T}$ cells from old mice improved after mitotransfer was also examined. CD4 ${ }^{+} \mathrm{T}$ cells from old mice were stimulated for $72 \mathrm{~h}$ in complete media supplemented with $50 \mu \mathrm{M}$ EdU. EdU is incorporated into newly synthesized DNA during cell proliferation, and its incorporation can be detected through fluorescent conjugation and flow cytometric analysis. Compared to non-manipulated CD4+ $\mathrm{T}$ cells from old mice, CD4+ $\mathrm{T}$ cells after mito-transfer had a two-fold increase in the number of Edu+ cells (Fig. 7.I, Supp. Fig 5.). These data suggest that mito-transfer increased the proliferative capacity of CD4+ $\mathrm{T}$ cells from old mice. Collectively, mito-transfer improved T cell activation, production of IL-2, proliferation, and broadly impacted cytokine miliue of $\mathrm{CD}^{+} \mathrm{T}$ cells from old mice. Our data also confirm that the improved cytokine production in CD4+ $\mathrm{T}$ cells from old mice was redox-dependent, as responses increased and decreased accordingly in the presence of $\mathrm{NAC}$ and $\mathrm{H}_{2} \mathrm{O}_{2}$.

\section{Discussion:}

Mitochondria are indispensable for proper T cell homeostasis [13, 15, 17, 20, 27], and agingassociated decline in adaptive immunity is linked to mitochondrial dysfunction and redox imbalance [6, 17, 83-85]. The restoration of redox balance through the reconstitution of mitochondrial fitness in lymphocytes from old mice has not been thoroughly examined, and we 
hypothesized that restoration would improve immunological T cell function. Mito-transfer altered the basal levels of mitoROS and antioxidants in $\mathrm{CD} 4^{+} \mathrm{T}$ cells from old mice, shifting cells towards lower basal levels of intracellular ROS. In parallel, mito-transfer enhanced the cellular aerobic metabolism of $\mathrm{CD}^{+} \mathrm{T}$ cells from old mice. Combined, the changes in intracellular ROS and metabolism led to improved $\mathrm{T}$ cell function, identified by the increased expression of a $\mathrm{T}$ cell activation marker (CD25), cytokine production, and an increase in activation-induced proliferation. Compared to non-manipulated CD4 ${ }^{+} \mathrm{T}$ cells, the proportion of activated T cells expressing CD25 and CD69 doubled after mito-transfer and $24 \mathrm{~h}$ of activating stimulus. We also noted a concomitant doubling of $\mathrm{CD}^{+} \mathrm{T}$ cells producing IL-2, which correlated with increased cell proliferation, and contributed to the alteration of cytokine profiles. To our knowledge, we are the first to report functional changes associated with mito-transfer in CD4 ${ }^{+} \mathrm{T}$ cells from old mice ex vivo.

The enhancement of aerobic respiration (increased glycolysis and mitochondrial respiration) in $\mathrm{CD}^{+} \mathrm{T}$ cells from old mice after mito-transfer was particularly noticeable. Increased mitochondrial content and activity are likely responsible for the concurrent rise in glycolysis, as the amount of acetyl-CoA needed for the TCA cycle significantly increased. Acetyl-CoA is primarily generated either through $\beta$-oxidation of intracellular fatty acids or glycolysis [86]. We did not assess the preferential utilization of lipids in this study, and the medium preparation used to perform the metabolic analysis did not contain a significant amount of lipids. In line with Le Chatelier's principles of substrate equilibrium, it can be argued that after mito-transfer, CD4+ ${ }^{+} \mathrm{T}$ cells from old mice upregulated glycolysis to compensate for lagging intracellular levels of acetyl-CoA. Additionally, the ATP production rate of $\mathrm{CD}^{+} \mathrm{T}$ cells isolated from old mice rose by $40 \%$ in comparison to non-manipulated $\mathrm{CD}^{+} \mathrm{T}$ cells. Primary information regarding $\mathrm{T}$ cell metabolism in the context of aging is still sparse [87]. As of now, it seems the impact of mito-transfer on the 
metabolism of $\mathrm{CD}^{+} \mathrm{T}$ cells differs from the Warburg phenomenon, as there was no bias towards glycolysis, and mito-transfer decreased mitoROS in the CD4+ $\mathrm{T}$ cells from old mice.

Cells strive to maintain an optimum ratio of size to metabolic activity, including mitochondrial metabolism $[88,89]$. We hypothesized that the addition of excess mitochondria would elicit CD4+ T cells to re-establish a proper cell size to mitochondrial mass ratio. We confirmed by TEM that the total mitochondrial area (used as a surrogate of mitochondrial mass) of $\mathrm{CD}^{+}{ }^{+} \mathrm{T}$ cells from old mice initially increased after mito-transfer. However, $4 \mathrm{~h}$ after mito-transfer, the mitochondrial mass of $\mathrm{CD}^{+} \mathrm{T}$ cells from old mice had reduced significantly to lower than that measured in nonmanipulated $\mathrm{CD}^{+}{ }^{+} \mathrm{T}$ cells from old and young mice. Despite the reduction in mitochondrial mass, proteomic analysis from the same time point showed that $\mathrm{CD} 4^{+} \mathrm{T}$ cells from old mice receiving mito-transfer had increased levels of proteins related to the ETC. Collectively these data suggests that the inner mitochondrial cristae of $\mathrm{CD}^{+} \mathrm{T}$ cells restructured after mito-transfer, favoring increased cristae density per mitochondria rather than an increase in mitochondrial mass.

In a previous study, Nielsen et al. compared the mitochondrial volume and mitochondrial cristae density in skeletal biopsies from sedentary obese individuals, sedentary obese individuals with type 2 diabetes, recreationally active individuals, soccer players, and cross-country skiers by transmission electron microscopy [90]. The sedentary individuals (obese and diabetic) had comparable mitochondrial mass and cristae density, and these were significantly lower than that of recreationally active individuals, soccer players, and cross-country skiers [90]. The mitochondrial mass of recreationally active individuals, soccer players, and cross-country skiers were comparable, but cristae density was significantly higher in the endurance athletes [90]. Moreover, increased cristae density correlated with elevated oxygen consumption [90]. This study corroborates our hypothesis that mitochondrial cristae density likely increased in CD4+ ${ }^{+}$cells from old mice after mito-transfer. The change in mitochondrial dynamics likely contributed to the 
decline in mitoROS production. Increased cristae density would also explain why the level mitoROS was significantly higher than that of non-manipulated CD4+ $\mathrm{T}$ cells after mito-transfer and activation. We also noted that the switch from Ox-Phos to aerobic glycolysis in mitotransferred $\mathrm{CD}^{+} \mathrm{T}$ cells was much faster than that of non-manipulated $\mathrm{CD} 4^{+} \mathrm{T}$ cells from old mice.

The shift in redox balance in mito-transferred CD4 ${ }^{+} \mathrm{T}$ cells was accompanied by improved cellular response to mitogen activation, increased number of cells that secrete IL-2 and IFN $\gamma$, as well as enhanced T cell proliferation. The IL-2 signaling pathway is immunomodulatory [91-93], and while CD4 ${ }^{+} \mathrm{T}$ cells, CD8 ${ }^{+} \mathrm{T}$ cells, NK cells, NK T cells, and dendritic cells are all capable of secreting IL2, activated $C D 4^{+} \mathrm{T}$ cells are its largest producer $[81,91,94]$. Previous research has shown that $\mathrm{CD}^{+} \mathrm{T}$ cells from elderly humans and mice produce insufficient amounts of IL-2, as well as insufficiently express the high-affinity IL-2 receptor IL-2Ra (CD25) necessary for signal transduction $[95,96]$, and current consensus is that aging-associated defects in IL-2 signaling can dynamically shift the architecture of adaptive immune response or even promote $\mathrm{T}$ cell anergy [5, 95, 97]. The underlying mechanics regarding stunted IL-2 production and related signaling in the elderly are still unclear $[5,97,98]$. Intracellular IL-2 signaling transduction occurs through the Janus kinase/signal transducer and activation of transcription factor (JAK/STAT), phosphoinositide-3-kinase (PI3K), and mitogen-activated kinase (MAPK) pathways, all of which are sensitive to oxidative modifications $[99,100]$. Previous studies have also characterized the role of redox equilibrium in maintaining proper lymphocyte function, and mitoROS, specifically $\mathrm{H}_{2} \mathrm{O}_{2}$, modulates IL-2 expression in T cells $[15,101]$. Supplementation with the antioxidant vitamin E improved the ability of T cells from the elderly to produce IL-2 and proliferate [102]. However, maintaining the intracellular redox balance is delicate [23, 36, 37], and excess antioxidants can hinder proper T cell activation and cytokine production as we and others have described [103, 104]. 
$\mathrm{CD}^{+} \mathrm{T}$ cell proliferation and differentiation into Th1, Th2, Tregs, and Th17 subsets are mediated through IL-2 signaling [91, 94], and IL-2 induces IFN $\gamma$ production and cellular proliferation of Th1 CD4+ T cells [81, 94]. In Th2 CD4+ T cells, IL-2 signaling promotes IL-4 receptor expression [94, 105]. IL-2 signaling also promotes the expansion of Tregs and represses Th17 CD4+ T cell $^{+}$ differentiation [93]. Our Luminex cytokine data suggest that the impact of mito-transfer extends beyond the IL-2 signaling pathway, as we noted changes to the amounts of Th1 (IFN $\chi$, TNFa), Th2 (IL-4, IL-15), Th17 (IL-17a) and Treg (IL-10) cytokines in the media of activated mitotransferred CD4+ $\mathrm{T}$ cells at 24 and $72 \mathrm{~h}$ post stimulation. The chemokine CCL-5/RANTES, whose production is upregulated after T cell activation [106, 107], was also significantly higher in the media of mito-transferred CD4 ${ }^{+} \mathrm{T}$ cells from old mice. CCL-5 and its cognate receptor CCR5 mediate T cell chemotaxis and influence the glycolytic metabolism of activated T cells via mTOR signaling $[108,109]$. The increased levels of CCL-5 in the media of mito-transferred CD4+ $4^{+}$cells further corroborates the increased activation status reported in our flow cytometry analysis and suggests that compared to non-manipulated old CD4 ${ }^{+} \mathrm{T}$ cells, mito-transferred $\mathrm{CD} 4^{+} \mathrm{T}$ cells from old mice may have enhanced chemotaxis. In short, we speculate that the redox shift generated by mito-transfer improved a myriad of intracellular signaling cascades in CD4 ${ }^{+} \mathrm{T}$ cells from old mice, and future mechanistic studies will be needed to completely elucidate all of the impacted pathways.

Aging-associated immune dysfunction, as well as the progression of aging-associated pathologies like cancer, diabetes, and Alzheimer's, are interrelated through altered immune responses and metabolic reprogramming that favors disease progression [45, 56, 110, 111]. Regarding mitochondrial dysfunction, therapeutic strategies have targeted reducing redox imbalance, optimizing cellular metabolism, or facilitating mitochondrial turnover and biogenesis $[27,56,111-117]$. Although these strategies reduced the toxicity and associated functional 
abnormalities, most therapies fail to fix the underlying mitochondrial dysfunction. MtDNA damage seems to be a root cause of aging-associated mitochondrial dysfunction [118-120]. Therefore, we must devise strategies to repair mtDNA. Delivery of mtDNA to donor cells termed mitochondrial replacement therapy (MRT), has been attempted in the past to permanently improve mitochondrial function [121-123]. MRT is used during instances of in vitro fertilization (IVF) that have repeated implantation failures [116] where donor cytoplasm and mitochondria, or egg genetic material (maternal spindle), from a healthy individual, are delivered to a recipient egg. Mito-transfer is akin to MRT, but instead of delivering mtDNA, whole mitochondria are inserted into malignant cells. Others have applied the principles of MRT and mito-transfer to ameliorate mitochondrial dysfunction in other disease models including cancer, sciatic nerve injury, ischemia, and Parkinson's [121, 124].

The capacity to upscale the process of mito-transfer from in vitro/ex vivo towards in vivo models is likely limited by available techniques to perform MRT and the number of viable mitochondria or mtDNA needed to revert a specific mitochondrial metabolic abnormality in an organism [121, 125]. Mitochondrial encapsulation or injections can facilitate in vivo studies [124, 126] and Chang et al. showed that cell-penetrating peptide (pep-1) mediated delivery of healthy mitochondria to MCF7 breast cancer cells reversed Warburg metabolism, decreased oxidative stress, and increased cancer cell susceptibility to chemotherapeutics [124].

In conclusion, under our experimental conditions, mito-transfer decreased mitochondrial dysfunction, improved activation, cytokine production, and proliferation of $\mathrm{CD}^{+} \mathrm{T}$ cells from old mice. In addition to mitoROS mediated redox signaling [127-131], calcium mobilization and buffering in coordination with the endoplasmic reticulum (ER) [13, 23, 42, 132], cytochrome $c$ mediated apoptosis [133-137], NAD+ mediated epigenetic regulation (sirtuins) [138, 139], as well as protein transport and degradation [140, 141], are all interdependent on proper mitochondrial 
form and function. We suspect that the impact of mito-transfer on other aspects of T cell function were also improved. However, in-depth mechanistic studies will be needed to elucidate the specific means by which mito-transfer altered the pathways in CD4+ $\mathrm{T}$ cells from old mice.

\section{Acknowledgments.}

We would like to acknowledge the thoughtful discussions with Drs. Yufeng Wang, Susan Weintraub, Larry Schlesinger, and Douglas Green that have strengthened this manuscript. We would also like to acknowledge Drs. Gourav Choudhury and Marcel Daadi for sharing their MEF isolation protocol.

\section{Funding:}

This project was supported by a National Institute of Health, National Institute on Aging Program

Project Grant (PPG) to JT (AG051428), and the Douglass Foundation Graduate Student Fellowship to $\mathrm{CAH}$ (4674).

Conflict of interest: The authors declare no competing interests.

Author Contributions: This project was conceived by $\mathrm{CAH} \& \mathrm{JT}$; $\mathrm{CAH}$ designed the experiments; $\mathrm{CAH}, \mathrm{SG}, \mathrm{AA}, \mathrm{VD}$, and RA performed the experiments; $\mathrm{CAH}$ and JG performed statistical analysis, $\mathrm{CAH}$ wrote the manuscript; $\mathrm{CAH}, \mathrm{JBT}$ and JT edited the manuscript) 
1. Orme, I.M., Aging and immunity to tuberculosis: increased susceptibility of old mice reflects a decreased capacity to generate mediator T lymphocytes. J Immunol, 1987. 138(12): p. 4414-8.

2. Weyand, C.M. and J.J. Goronzy, Aging of the Immune System. Mechanisms and Therapeutic Targets. Ann Am Thorac Soc, 2016. 13 Suppl 5: p. S422-S428.

3. Herndler-Brandstetter, D., How aging affects $T$ lymphocyte-mediated immunity. Front Immunol, 2013. 4: p. 296.

4. Akbar, A.N., S.M. Henson, and A. Lanna, Senescence of T Lymphocytes: Implications for Enhancing Human Immunity. Trends Immunol, 2016. 37(12): p. 866-876.

5. Donnini, A., et al., Age-related susceptibility of naive and memory CD4 T cells to apoptosis induced by IL-2 deprivation or PHA addition. Biogerontology, 2005. 6(3): p. 193-204.

6. Mattoo, H., et al., Naive CD4 T cells from aged mice show enhanced death upon primary activation. Int Immunol, 2009. 21(11): p. 1277-89.

7. Lefebvre, J.S. and L. Haynes, Aging of the CD4 T Cell Compartment. Open Longev Sci, 2012. 6: p. 83-91.

8. Nikolich-Zugich, J., Aging of the $T$ cell compartment in mice and humans: from no naive expectations to foggy memories. J Immunol, 2014. 193(6): p. 2622-9.

9. Haynes, L., et al., CD4 T cell memory derived from young naive cells functions well into old age, but memory generated from aged naive cells functions poorly. Proc Natl Acad Sci U S A, 2003. 100(25): p. 15053-8.

10. Yanes, R.E., et al., Metabolic reprogramming in memory CD4 T cell responses of old adults. Clin Immunol, 2019. 207: p. 58-67.

11. Pieren, D.K.J., et al., Response kinetics reveal novel features of ageing in murine $T$ cells. Sci Rep, 2019. 9(1): p. 5587.

12. Mirza, N., et al., Comparative kinetic analyses of gene profiles of naive CD4+ and CD8+T cells from young and old animals reveal novel age-related alterations. Aging Cell, 2011. 10(5): p. 853-67.

13. Nagy, G., A. Koncz, and A. Perl, $T$ cell activation-induced mitochondrial hyperpolarization is mediated by Ca2+- and redox-dependent production of nitric oxide. J Immunol, 2003. 171(10): p. 5188-97.

14. Quintana, A., et al., $T$ cell activation requires mitochondrial translocation to the immunological synapse. Proc Natl Acad Sci U S A, 2007. 104(36): p. 14418-23.

15. Kaminski, M.M., et al., Mitochondrial reactive oxygen species control T cell activation by regulating IL-2 and IL-4 expression: mechanism of ciprofloxacin-mediated immunosuppression. J Immunol, 2010. 184(9): p. 4827-41.

16. Fracchia, K.M., C.Y. Pai, and C.M. Walsh, Modulation of T Cell Metabolism and Function through Calcium Signaling. Front Immunol, 2013. 4: p. 324.

17. Ron-Harel, N., A.H. Sharpe, and M.C. Haigis, Mitochondrial metabolism in T cell activation and senescence: a mini-review. Gerontology, 2015. 61(2): p. 131-8.

18. Leavy, O., T Cell responses: Defective mitochondria disrupt CD8(+) T cells. Nat Rev Immunol, 2016. 16(9): p. 534-5.

19. Buck, M.D., et al., Mitochondrial Dynamics Controls T Cell Fate through Metabolic Programming. Cell, 2016. 166(1): p. 63-76.

20. Almeida, L., et al., Metabolic pathways in $T$ cell activation and lineage differentiation. Semin Immunol, 2016. 28(5): p. 514-524.

21. Dimeloe, S., et al., T-cell metabolism governing activation, proliferation and differentiation; $a$ modular view. Immunology, 2017. 150(1): p. 35-44.

22. Patel, C.H. and J.D. Powell, Targeting T cell metabolism to regulate T cell activation, differentiation and function in disease. Curr Opin Immunol, 2017. 46: p. 82-88. 
23. Desdin-Mico, G., G. Soto-Heredero, and M. Mittelbrunn, Mitochondrial activity in $T$ cells. Mitochondrion, 2018. 41: p. 51-57.

24. Perl, A., R. Hanczko, and E. Doherty, Assessment of mitochondrial dysfunction in lymphocytes of patients with systemic lupus erythematosus. Methods Mol Biol, 2012. 900: p. 61-89.

25. Bhargava, A., et al., Role of mitochondrial oxidative stress on lymphocyte homeostasis in patients diagnosed with extra-pulmonary tuberculosis. Cell Biol Int, 2016. 40(2): p. 166-76.

26. Sanderson, S.L. and A.K. Simon, In aged primary $T$ cells, mitochondrial stress contributes to telomere attrition measured by a novel imaging flow cytometry assay. Aging Cell, 2017. 16(6): p. 1234-1243.

27. Fisicaro, P., et al., Targeting mitochondrial dysfunction can restore antiviral activity of exhausted HBV-specific CD8 T cells in chronic hepatitis B. Nat Med, 2017. 23(3): p. 327-336.

28. Adam-Vizi, V. and C. Chinopoulos, Bioenergetics and the formation of mitochondrial reactive oxygen species. Trends Pharmacol Sci, 2006. 27(12): p. 639-45.

29. Murphy, M.P., How mitochondria produce reactive oxygen species. Biochem J, 2009. 417(1): p. 113.

30. Venditti, P., L. Di Stefano, and S. Di Meo, Mitochondrial metabolism of reactive oxygen species. Mitochondrion, 2013. 13(2): p. 71-82.

31. Zorov, D.B., M. Juhaszova, and S.J. Sollott, Mitochondrial reactive oxygen species (ROS) and ROSinduced ROS release. Physiol Rev, 2014. 94(3): p. 909-50.

32. Gill, T. and A.D. Levine, Mitochondria-derived hydrogen peroxide selectively enhances $T$ cell receptor-initiated signal transduction. J Biol Chem, 2013. 288(36): p. 26246-55.

33. Kim, H.J., et al., Exogenous Hydrogen Peroxide Induces Lipid Raft-Mediated STAT-6 Activation in T Cells. Cell Physiol Biochem, 2017. 42(6): p. 2467-2480.

34. Reth, M., Hydrogen peroxide as second messenger in lymphocyte activation. Nat Immunol, 2002. 3(12): p. 1129-34.

35. Ball, J.A., et al., Hydrogen Peroxide Triggers a Dual Signaling Axis To Selectively Suppress Activated Human T Lymphocyte Migration. J Immunol, 2017. 198(9): p. 3679-3689.

36. Yarosz, E.L. and C.H. Chang, The Role of Reactive Oxygen Species in Regulating T Cell-mediated Immunity and Disease. Immune Netw, 2018. 18(1): p. e14.

37. Belikov, A.V., B. Schraven, and L. Simeoni, T cells and reactive oxygen species. J Biomed Sci, 2015. 22: p. 85.

38. Poderoso, J.J., The formation of peroxynitrite in the applied physiology of mitochondrial nitric oxide. Arch Biochem Biophys, 2009. 484(2): p. 214-20.

39. Rimessi, A., et al., Mitochondrial reactive oxygen species and inflammation: Molecular mechanisms, diseases and promising therapies. Int J Biochem Cell Biol, 2016. 81(Pt B): p. 281-293.

40. Davies, M.J., Protein oxidation and peroxidation. Biochem J, 2016. 473(7): p. 805-25.

41. Dan Dunn, J., et al., Reactive oxygen species and mitochondria: A nexus of cellular homeostasis. Redox Biol, 2015. 6: p. 472-85.

42. Osellame, L.D., T.S. Blacker, and M.R. Duchen, Cellular and molecular mechanisms of mitochondrial function. Best Pract Res Clin Endocrinol Metab, 2012. 26(6): p. 711-23.

43. Mills, E.L., B. Kelly, and L.A.J. O'Neill, Mitochondria are the powerhouses of immunity. Nat Immunol, 2017. 18(5): p. 488-498.

44. Lanna, A. and M.L. Dustin, Mitochondrial fusion fuels T cell memory. Cell Res, 2016. 26(9): p. 96970.

45. Czajka, A., et al., Altered Mitochondrial Function, Mitochondrial DNA and Reduced Metabolic Flexibility in Patients With Diabetic Nephropathy. EBioMedicine, 2015. 2(6): p. 499-512.

46. Zsurka, G., et al., Is There Still Any Role for Oxidative Stress in Mitochondrial DNA-Dependent Aging? Genes (Basel), 2018. 9(4). 
47. Ziada, A.S., et al., Mitochondrial DNA somatic mutation burden and heteroplasmy are associated with chronological age, smoking, and HIV infection. Aging Cell, 2019. 18(6): p. e13018.

48. Mikhed, Y., A. Daiber, and S. Steven, Mitochondrial Oxidative Stress, Mitochondrial DNA Damage and Their Role in Age-Related Vascular Dysfunction. Int J Mol Sci, 2015. 16(7): p. 15918-53.

49. Lagouge, M. and N.G. Larsson, The role of mitochondrial DNA mutations and free radicals in disease and ageing. J Intern Med, 2013. 273(6): p. 529-43.

50. Brand, M.D. and D.G. Nicholls, Assessing mitochondrial dysfunction in cells. Biochem J, 2011. 435(2): p. 297-312.

51. Brookes, P.S., Mitochondrial $\mathrm{H}(+)$ leak and ROS generation: an odd couple. Free Radic Biol Med, 2005. 38(1): p. 12-23.

52. Suski, J., et al., Relation Between Mitochondrial Membrane Potential and ROS Formation. Methods Mol Biol, 2018. 1782: p. 357-381.

53. Georgieva, E., et al., Detection of Redox Imbalance in Normal Lymphocytes with Induced Mitochondrial Dysfunction - EPR Study. Anticancer Res, 2016. 36(10): p. 5273-5279.

54. Lichtenfels, R., et al., Comparative expression profiling of distinct $T$ cell subsets undergoing oxidative stress. PLoS One, 2012. 7(7): p. e41345.

55. Holmdahl, R., et al., Hydrogen peroxide as an immunological transmitter regulating autoreactive $T$ cells. Antioxid Redox Signal, 2013. 18(12): p. 1463-74.

56. Jitschin, R., et al., Mitochondrial metabolism contributes to oxidative stress and reveals therapeutic targets in chronic lymphocytic leukemia. Blood, 2014. 123(17): p. 2663-72.

57. Franchina, D.G., C. Dostert, and D. Brenner, Reactive Oxygen Species: Involvement in T Cell Signaling and Metabolism. Trends Immunol, 2018. 39(6): p. 489-502.

58. Agrawal, A. and U. Mabalirajan, Rejuvenating cellular respiration for optimizing respiratory function: targeting mitochondria. Am J Physiol Lung Cell Mol Physiol, 2016. 310(2): p. L103-13.

59. A, E.M., Isolation and propagation of mouse embryonic fibroblasts and preparation of mouse embryonic feeder layer cells. Curr Protoc Stem Cell Biol, 2007. Chapter 1: p. Unit1C 3.

60. Kim, M.J., et al., Delivery of exogenous mitochondria via centrifugation enhances cellular metabolic function. Sci Rep, 2018. 8(1): p. 3330.

61. Schindelin, J., et al., Fiji: an open-source platform for biological-image analysis. Nat Methods, 2012. 9(7): p. 676-82.

62. Searle, B.C., et al., Chromatogram libraries improve peptide detection and quantification by data independent acquisition mass spectrometry. Nat Commun, 2018. 9(1): p. 5128.

63. Rosenberger, G., et al., A repository of assays to quantify 10,000 human proteins by SWATH-MS. Sci Data, 2014. 1: p. 140031.

64. Sun, X., et al., Flow cytometric analysis of T lymphocyte proliferation in vivo by EdU incorporation. Int Immunopharmacol, 2016. 41: p. 56-65.

65. Leung, C.W., et al., Superior fluorescent probe for detection of cardiolipin. Anal Chem, 2014. 86(2): p. $1263-8$.

66. Dudek, J., Role of Cardiolipin in Mitochondrial Signaling Pathways. Front Cell Dev Biol, 2017. 5: p. 90.

67. Paradies, G., et al., Oxidative stress, mitochondrial bioenergetics, and cardiolipin in aging. Free Radic Biol Med, 2010. 48(10): p. 1286-95.

68. Paradies, G., et al., Functional role of cardiolipin in mitochondrial bioenergetics. Biochim Biophys Acta, 2014. 1837(4): p. 408-17.

69. Osman, C., D.R. Voelker, and T. Langer, Making heads or tails of phospholipids in mitochondria. J Cell Biol, 2011. 192(1): p. 7-16.

70. Mookerjee, S.A., et al., The contributions of respiration and glycolysis to extracellular acid production. Biochim Biophys Acta, 2015. 1847(2): p. 171-181. 
71. Yoshioka, K., et al., Intracellular fate of 2-NBDG, a fluorescent probe for glucose uptake activity, in Escherichia coli cells. Biosci Biotechnol Biochem, 1996. 60(11): p. 1899-901.

72. Kim, W.H., et al., Visualizing sweetness: increasingly diverse applications for fluorescent-tagged glucose bioprobes and their recent structural modifications. Sensors (Basel), 2012. 12(4): p. 500527.

73. Bonora, M., et al., ATP synthesis and storage. Purinergic Signal, 2012. 8(3): p. 343-57.

74. Mookerjee, S.A., et al., Quantifying intracellular rates of glycolytic and oxidative ATP production and consumption using extracellular flux measurements. J Biol Chem, 2017. 292(17): p. 71897207.

75. Brand, M.D., et al., The basal proton conductance of mitochondria depends on adenine nucleotide translocase content. Biochem J, 2005. 392(Pt 2): p. 353-62.

76. Menk, A.V., et al., Early TCR Signaling Induces Rapid Aerobic Glycolysis Enabling Distinct Acute T Cell Effector Functions. Cell Rep, 2018. 22(6): p. 1509-1521.

77. Wang, R. and D.R. Green, Metabolic checkpoints in activated T cells. Nat Immunol, 2012. 13(10): p. 907-15.

78. Macintyre, A.N., et al., The glucose transporter Glut1 is selectively essential for CD4 T cell activation and effector function. Cell Metab, 2014. 20(1): p. 61-72.

79. Cao, Y., J.C. Rathmell, and A.N. Macintyre, Metabolic reprogramming towards aerobic glycolysis correlates with greater proliferative ability and resistance to metabolic inhibition in CD8 versus CD4 T cells. PLoS One, 2014. 9(8): p. e104104.

80. Palmer, C.S., et al., Glucose metabolism regulates T cell activation, differentiation, and functions. Front Immunol, 2015. 6: p. 1.

81. Malek, T.R. and I. Castro, Interleukin-2 receptor signaling: at the interface between tolerance and immunity. Immunity, 2010. 33(2): p. 153-65.

82. Shatrova, A.N., et al., Time-Dependent Regulation of IL-2R alpha-Chain (CD25) Expression by TCR Signal Strength and IL-2-Induced STAT5 Signaling in Activated Human Blood T Lymphocytes. PLoS One, 2016. 11(12): p. e0167215.

83. Pattabiraman, G., et al., Aging-associated dysregulation of homeostatic immune response termination (and not initiation). Aging Cell, 2017. 16(3): p. 585-593.

84. Ron-Harel, N., et al., Defective respiration and one-carbon metabolism contribute to impaired naive T cell activation in aged mice. Proc Natl Acad Sci U S A, 2018. 115(52): p. 13347-13352.

85. Ghatreh-Samani, M., et al., Oxidative stress and age-related changes in T cells: is thalassemia a model of accelerated immune system aging? Cent Eur J Immunol, 2016. 41(1): p. 116-24.

86. Shi, L. and B.P. Tu, Acetyl-CoA and the regulation of metabolism: mechanisms and consequences. Curr Opin Cell Biol, 2015. 33: p. 125-31.

87. Quinn, K.M., et al., The clock is ticking: the impact of ageing on T cell metabolism. Clin Transl Immunology, 2019. 8(11): p. e01091.

88. Miettinen, T.P. and M. Bjorklund, Cellular Allometry of Mitochondrial Functionality Establishes the Optimal Cell Size. Dev Cell, 2016. 39(3): p. 370-382.

89. Miettinen, T.P. and M. Bjorklund, Mitochondrial Function and Cell Size: An Allometric Relationship. Trends Cell Biol, 2017. 27(6): p. 393-402.

90. Nielsen, J., et al., Plasticity in mitochondrial cristae density allows metabolic capacity modulation in human skeletal muscle. J Physiol, 2017. 595(9): p. 2839-2847.

91. Ross, S.H. and D.A. Cantrell, Signaling and Function of Interleukin-2 in T Lymphocytes. Annu Rev Immunol, 2018. 36: p. 411-433.

92. Gaffen, S.L. and K.D. Liu, Overview of interleukin-2 function, production and clinical applications. Cytokine, 2004. 28(3): p. 109-23. 
93. Busse, D., et al., Competing feedback loops shape IL-2 signaling between helper and regulatory $T$ lymphocytes in cellular microenvironments. Proc Natl Acad Sci U S A, 2010. 107(7): p. 3058-63.

94. Liao, W., J.X. Lin, and W.J. Leonard, Interleukin-2 at the crossroads of effector responses, tolerance, and immunotherapy. Immunity, 2013. 38(1): p. 13-25.

95. Pahlavani, M.A. and A. Richardson, The effect of age on the expression of interleukin-2. Mech Ageing Dev, 1996. 89(3): p. 125-54.

96. Thoman, M.L. and W.O. Weigle, Lymphokines and aging: interleukin-2 production and activity in aged animals. J Immunol, 1981. 127(5): p. 2102-6.

97. Haynes, L., et al., Interleukin 2, but not other common gamma chain-binding cytokines, can reverse the defect in generation of CD4 effector T cells from naive T cells of aged mice. J Exp Med, 1999. 190(7): p. 1013-24.

98. Gardner, E.M. and D.M. Murasko, Age-related changes in Type 1 and Type 2 cytokine production in humans. Biogerontology, 2002. 3(5): p. 271-90.

99. Simeoni, L. and I. Bogeski, Redox regulation of T-cell receptor signaling. Biol Chem, 2015. 396(5): p. 555-68.

100. Kesarwani, P., et al., Redox regulation of T-cell function: from molecular mechanisms to significance in human health and disease. Antioxid Redox Signal, 2013. 18(12): p. 1497-534.

101. Sena, L.A., et al., Mitochondria are required for antigen-specific T cell activation through reactive oxygen species signaling. Immunity, 2013. 38(2): p. 225-36.

102. Marko, M.G., et al., Age-associated decline in effective immune synapse formation of CD4(+) $T$ cells is reversed by vitamin E supplementation. J Immunol, 2007. 178(3): p. 1443-9.

103. Previte, D.M. and J.D. Piganelli, Reactive Oxygen Species and Their Implications on CD4(+) T Cells in Type 1 Diabetes. Antioxid Redox Signal, 2017.

104. Previte, D.M., et al., Reactive oxygen species are required for driving efficient and sustained aerobic glycolysis during CD4+ T cell activation. PLoS One, 2017. 12(4): p. e0175549.

105. Cote-Sierra, J., et al., Interleukin 2 plays a central role in Th2 differentiation. Proc Natl Acad Sci U S A, 2004. 101(11): p. 3880-5.

106. Swanson, B.J., et al., RANTES production by memory phenotype $T$ cells is controlled by a posttranscriptional, TCR-dependent process. Immunity, 2002. 17(5): p. 605-15.

107. Crawford, A., et al., A role for the chemokine RANTES in regulating CD8 $T$ cell responses during chronic viral infection. PLoS Pathog, 2011. 7(7): p. e1002098.

108. Chan, O., et al., The chemokine CCL5 regulates glucose uptake and AMP kinase signaling in activated T cells to facilitate chemotaxis. J Biol Chem, 2012. 287(35): p. 29406-16.

109. Murooka, T.T., et al., CCL5-mediated T-cell chemotaxis involves the initiation of mRNA translation through mTOR/4E-BP1. Blood, 2008. 111(10): p. 4892-901.

110. Baik, S.H., et al., A Breakdown in Metabolic Reprogramming Causes Microglia Dysfunction in Alzheimer's Disease. Cell Metab, 2019. 30(3): p. 493-507 e6.

111. Yoshida, G.J., Metabolic reprogramming: the emerging concept and associated therapeutic strategies. J Exp Clin Cancer Res, 2015. 34: p. 111.

112. Mazumdar, C., E.M. Driggers, and L.A. Turka, The Untapped Opportunity and Challenge of Immunometabolism: A New Paradigm for Drug Discovery. Cell Metab, 2020. 31(1): p. 26-34.

113. Moon, J., H.R. Kim, and M.G. Shin, Rejuvenating Aged Hematopoietic Stem Cells Through Improvement of Mitochondrial Function. Ann Lab Med, 2018. 38(5): p. 395-401.

114. Rossman, M.J., et al., Chronic Supplementation With a Mitochondrial Antioxidant (MitoQ) Improves Vascular Function in Healthy Older Adults. Hypertension, 2018. 71(6): p. 1056-1063.

115. Tan, A.S., et al., Mitochondrial genome acquisition restores respiratory function and tumorigenic potential of cancer cells without mitochondrial DNA. Cell Metab, 2015. 21(1): p. 81-94. 
116. Tachibana, M., T. Kuno, and N. Yaegashi, Mitochondrial replacement therapy and assisted reproductive technology: A paradigm shift toward treatment of genetic diseases in gametes or in early embryos. Reprod Med Biol, 2018. 17(4): p. 421-433.

117. Le Bourgeois, T., et al., Targeting T Cell Metabolism for Improvement of Cancer Immunotherapy. Front Oncol, 2018. 8: p. 237.

118. Kauppila, T.E.S., J.H.K. Kauppila, and N.G. Larsson, Mammalian Mitochondria and Aging: An Update. Cell Metab, 2017. 25(1): p. 57-71.

119. Srivastava, S., The Mitochondrial Basis of Aging and Age-Related Disorders. Genes (Basel), 2017. 8(12).

120. Larsson, N.G., Somatic mitochondrial DNA mutations in mammalian aging. Annu Rev Biochem, 2010. 79: p. 683-706.

121. Caicedo, A., et al., Artificial Mitochondria Transfer: Current Challenges, Advances, and Future Applications. Stem Cells Int, 2017. 2017: p. 7610414.

122. Moschoi, R., et al., Protective mitochondrial transfer from bone marrow stromal cells to acute myeloid leukemic cells during chemotherapy. Blood, 2016. 128(2): p. 253-64.

123. Spikings, E.C., J. Alderson, and J.C. St John, Transmission of mitochondrial DNA following assisted reproduction and nuclear transfer. Hum Reprod Update, 2006. 12(4): p. 401-15.

124. Chang, J.C., et al., Mitochondrial transplantation regulates antitumour activity, chemoresistance and mitochondrial dynamics in breast cancer. J Exp Clin Cancer Res, 2019. 38(1): p. 30.

125. Patananan, A.N., et al., Modifying the Mitochondrial Genome. Cell Metab, 2016. 23(5): p. 785-96.

126. Chen, W., et al., Mitochondrial Surface Engineering for Multidrug Resistance Reversal. Nano Lett, 2019. 19(5): p. 2905-2913.

127. Kang, J. and S. Pervaiz, Mitochondria: redox metabolism and dysfunction. Biochem Res Int, 2012. 2012: p. 896751.

128. Case, A.J., et al., Mitochondrial Superoxide Signaling Contributes to Norepinephrine-Mediated TLymphocyte Cytokine Profiles. PLoS One, 2016. 11(10): p. e0164609.

129. Moldovan, L. and N.I. Moldovan, Oxygen free radicals and redox biology of organelles. Histochem Cell Biol, 2004. 122(4): p. 395-412.

130. Handy, D.E. and J. Loscalzo, Redox regulation of mitochondrial function. Antioxid Redox Signal, 2012. 16(11): p. 1323-67.

131. Mailloux, R.J., S.L. McBride, and M.E. Harper, Unearthing the secrets of mitochondrial ROS and glutathione in bioenergetics. Trends Biochem Sci, 2013. 38(12): p. 592-602.

132. Bertero, E. and C. Maack, Calcium Signaling and Reactive Oxygen Species in Mitochondria. Circ Res, 2018. 122(10): p. 1460-1478.

133. Redza-Dutordoir, M. and D.A. Averill-Bates, Activation of apoptosis signalling pathways by reactive oxygen species. Biochim Biophys Acta, 2016. 1863(12): p. 2977-2992.

134. Giorgi, C., et al., Mitochondrial $\mathrm{Ca}(2+)$ and apoptosis. Cell Calcium, 2012. 52(1): p. 36-43.

135. Zhong, $\mathrm{H}$., et al., Mitochondrial control of apoptosis through modulation of cardiolipin oxidation in hepatocellular carcinoma: A novel link between oxidative stress and cancer. Free Radic Biol Med, 2017. 102: p. 67-76.

136. Kim, H.J. and A.E. Nel, The role of phase II antioxidant enzymes in protecting memory $T$ cells from spontaneous apoptosis in young and old mice. J Immunol, 2005. 175(5): p. 2948-59.

137. Petrosillo, G., F.M. Ruggiero, and G. Paradies, Role of reactive oxygen species and cardiolipin in the release of cytochrome c from mitochondria. FASEB J, 2003. 17(15): p. 2202-8.

138. Braidy, N., et al., Age related changes in NAD+ metabolism oxidative stress and Sirt1 activity in wistar rats. PLoS One, 2011. 6(4): p. e19194.

139. Christian, B.E. and G.S. Shadel, Aging: it's SIRTainly possible to restore mitochondrial dysfunction. Curr Biol, 2014. 24(5): p. R206-8. 
bioRxiv preprint doi: https://doi.org/10.1101/2021.02.21.432151; this version posted February 21, 2021. The copyright holder for this preprint

(which was not certified by peer review) is the author/funder, who has granted bioRxiv a license to display the preprint in perpetuity. It is made available under aCC-BY-ND 4.0 International license.

140. Mishra, P. and D.C. Chan, Metabolic regulation of mitochondrial dynamics. J Cell Biol, 2016. 212(4): p. 379-87.

141. Mohanty, A., R. Tiwari-Pandey, and N.R. Pandey, Mitochondria: the indispensable players in innate immunity and guardians of the inflammatory response. J Cell Commun Signal, 2019. 13(3): p. 303318. 

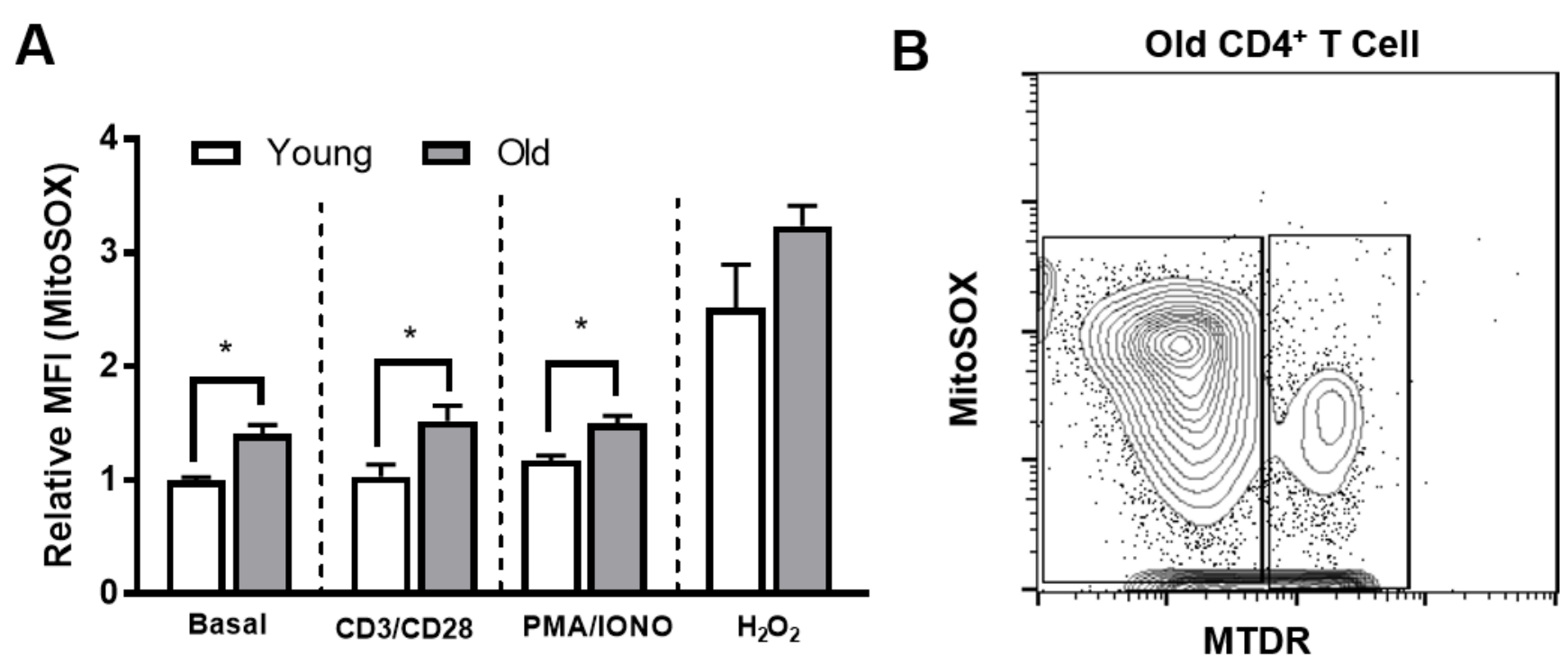

C

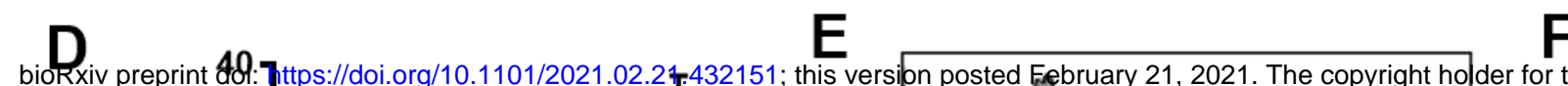

$\mathbf{F}_{\text {in }}$ reprin (which was not certified by peer review) is the author/fuhder, who has granted bioRxil a license to display the preprint in perpetuity. It is made
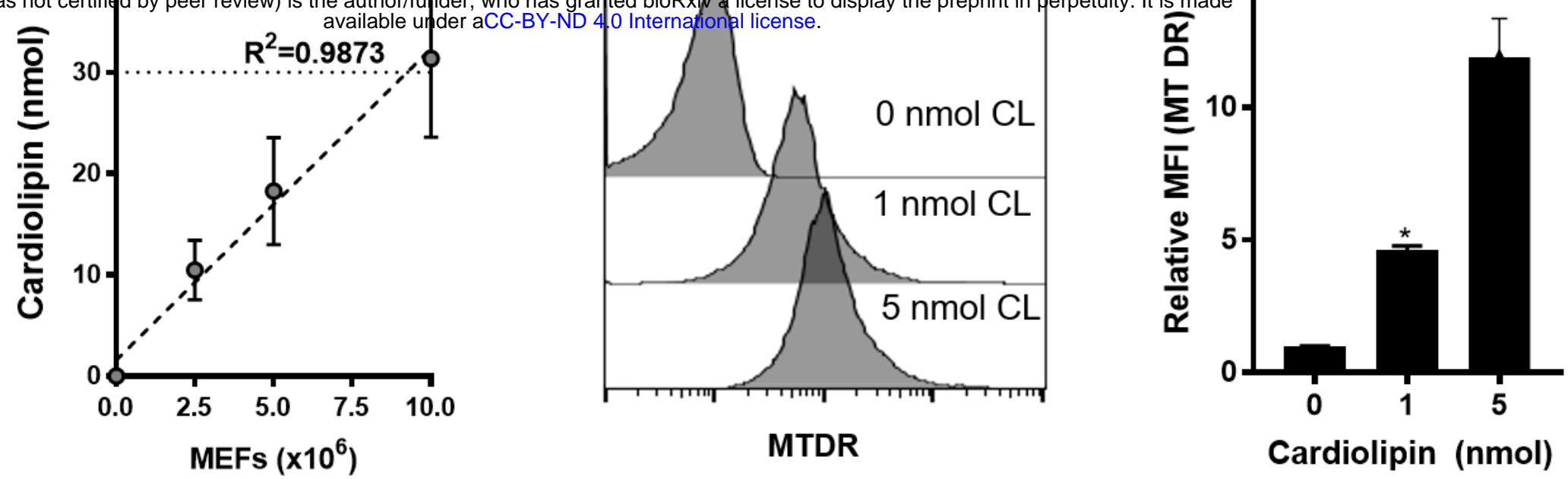

G

H

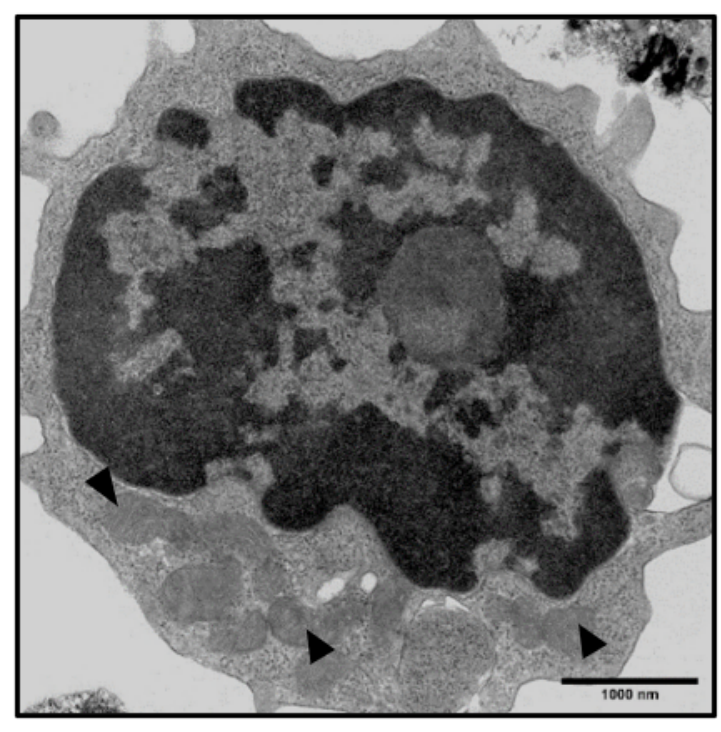

Young

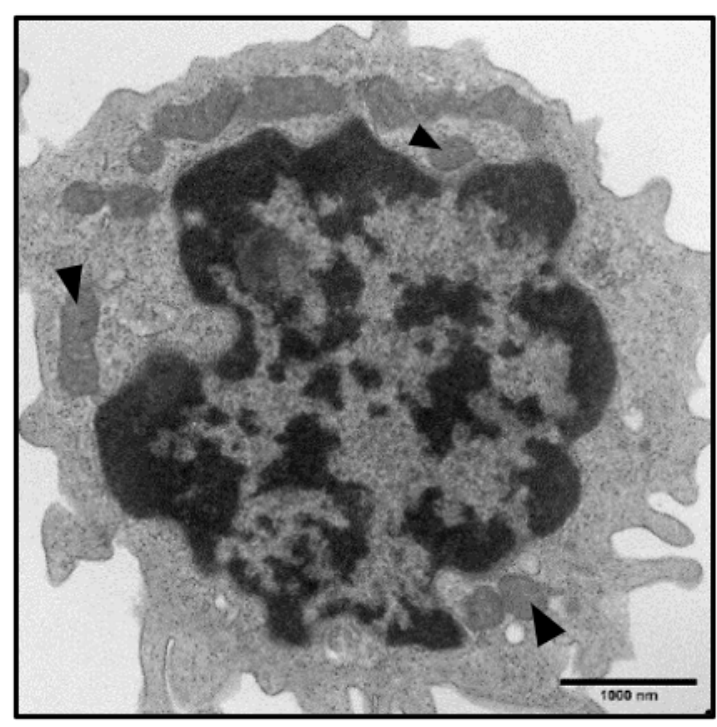

Old

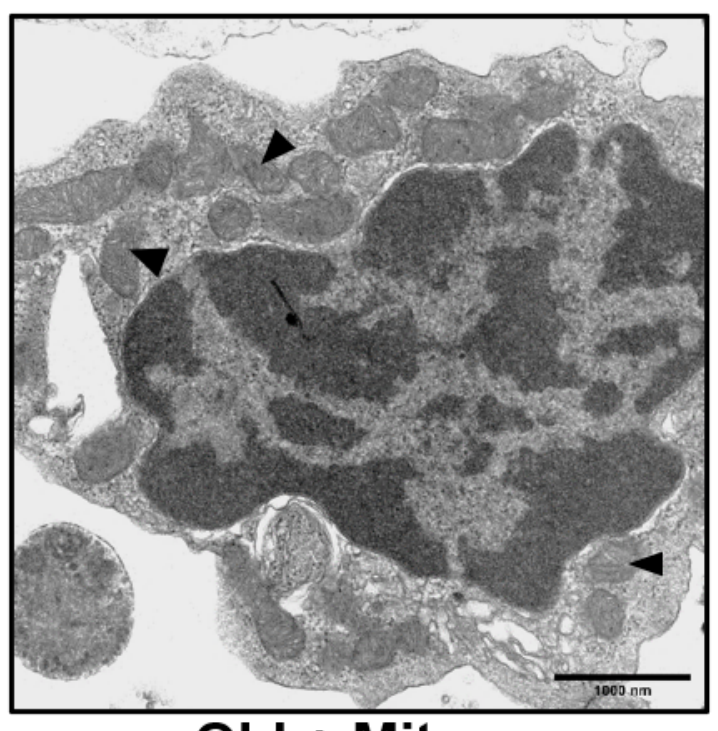

Old + Mito

J

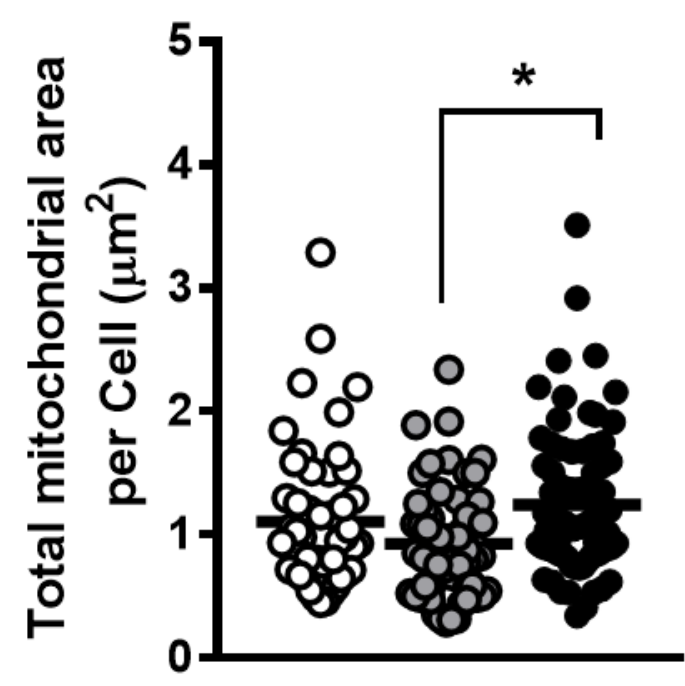

K

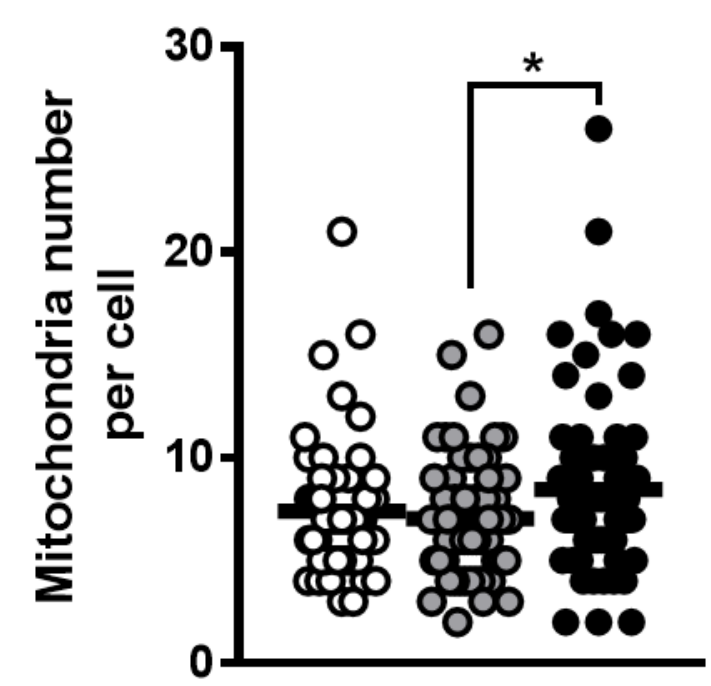

L

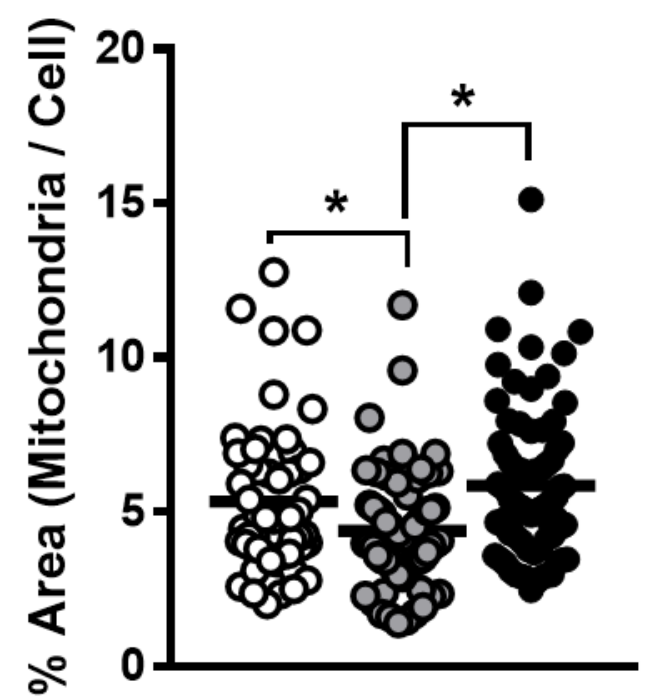

- Young o Old - Old + Mito

Fig. 1. 
Fig. 1. MitoROS \& mito-transfer in $\mathrm{CD}^{+} \mathrm{T}$ cells from old mice. CD4 ${ }^{+} \mathrm{T}$ cells isolated from young and old mice were either stimulated with various activation mimetics (CD3/CD28, PMA/IONO) or oxidative stress inducer (H2O2), prior to MitoSOX staining and quantitation via flow cytometry. A) Relative MFI of MitoSOX in CD4+ ${ }^{+}$cells isolated from young and old C57BL/6 mice basally, and after activation or oxidative stress cultures for $4 \mathrm{~h}$. B) Representative contour plot and C) bar graph of the impact of mito-transfer on mitoROS in $\mathrm{CD}^{+} \mathrm{T}$ cells from old mice. Mitochodria isolated from MEFs were pre-stained with MTDR and transplanted into CD4+ $4^{+}$cells from old mice. After mito-transfer, cells were probed with MitoSOX to determine mitoROS production. this experiment was done using 3 biological replicates. D) Cardiolipin concentration curve from isolated mitochondria, E) Flow cytometry histograms \& F) bar graphs of Mitotracker Deep Red (MTDR) tagged mitochondria isolated from MEF and transferred into CD4 ${ }^{+} \mathrm{T}$ cells from old mice. cardiolipin experiments were repeated twice with 3-4 mice/group. G-I) TEM images of $\mathrm{CD}^{+} \mathrm{T}$ cells (young, old, and old+mito) showing examples of mitochondria size and quantity (black arrows), Distributions of $\mathbf{J}$ ) total mitochondrial area per cell, $\mathbf{K}$ ) number of mitochondria per cell, and $\mathbf{L}$ ) \% area of mitochondria per area of cell in young, old and old CD4 ${ }^{+} \mathrm{T}$ cells after mitochondrial transfer. TEM images were obtained from 2 mice/group. $p<0.05=$ significant $\left(^{*}\right)$ using paired or unpaired Student's $t$-test, or one-way-ANOVA where appropriate. 
Fig. 2. Mito-transfer increased the cellular oxygen consumption, Glycolysis \& ATP production in $\mathrm{CD}^{+} \mathbf{T}$ cells from old mice. $\mathrm{CD} 4^{+} \mathrm{T}$ cells $\left(2.5 \times 10^{5}\right)$ were plated onto Poly-Dlysine coated 96 well microplates, after which $\mathrm{O}_{2}$ consumption (OCR) and extracellular acidification rates (ECAR) were measured under basal conditions and in response to Mito Stress Test. A) Representative Mito Stress test kinetic graph, B) Quantitation of Basal, maximal and spare respiratory capacity $\mathbf{C}$ ) Proton leak, non-mitochondrial oxygen consumption and ATP production rate, D) Coupling efficiency. E) Representative Glycolysis stress test kinetic graph, F) Quantitation of non-glycolytic acidification, glycolysis, glycolytic capacity and reserve, G) Flow histograms and H-I) Bar graphs of 2-NBDG uptake in young and old cells and old cell after mitotransfer, J-K) GLUT1 expression in CD4 ${ }^{+} \mathrm{T}$ cells from young and old mice, and CD4+ $\mathrm{T}$ cells from old mice after mito-transfer. Rates of $\mathbf{L}$ ) glycolysis and $\mathbf{M}$ ) mitochondrial-derived ATP, $\mathbf{N}$ ) total ATP production, and 0 ) cellular levels of ATP in $\mathrm{CD}^{+}{ }^{+} \mathrm{T}$ cells from young and old mice, and CD4 ${ }^{+}$ T cells from old mice after mito-transfer; 3-4 mice were used per group and experiments were replicated $(n=2), p<0.05=$ significant $\left(^{*}\right)$ using unpaired Student's $t$-test. 
A

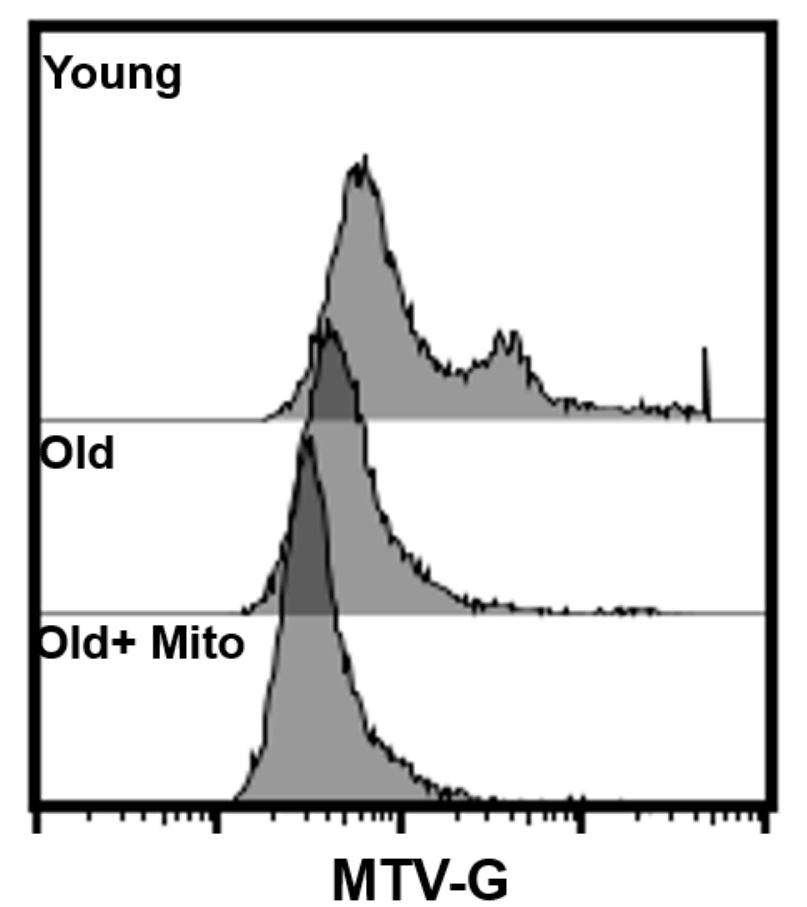

E

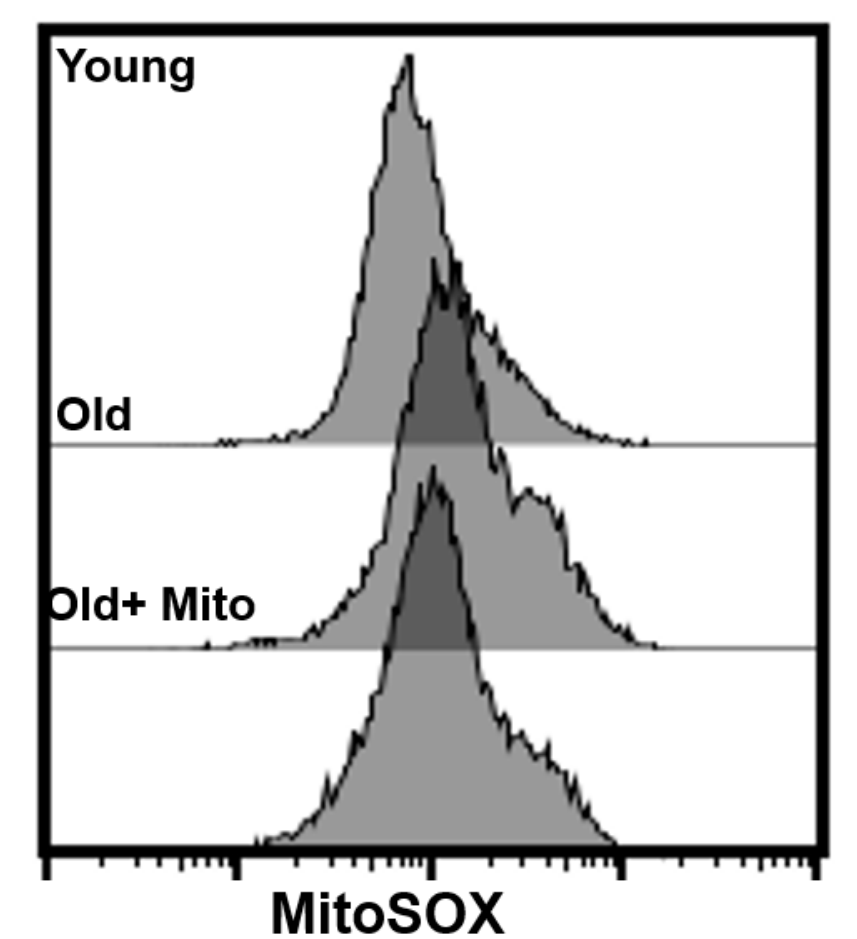

B

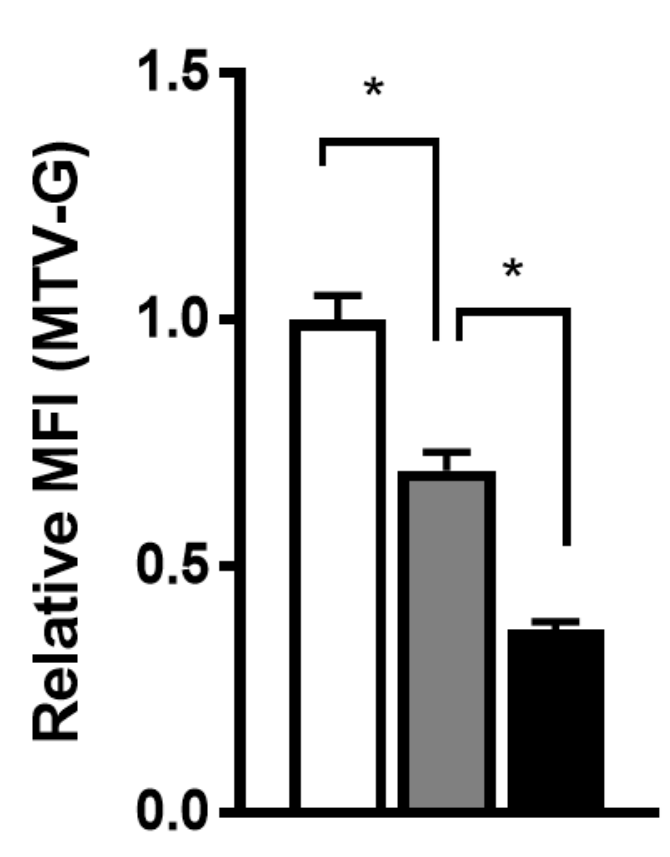

F

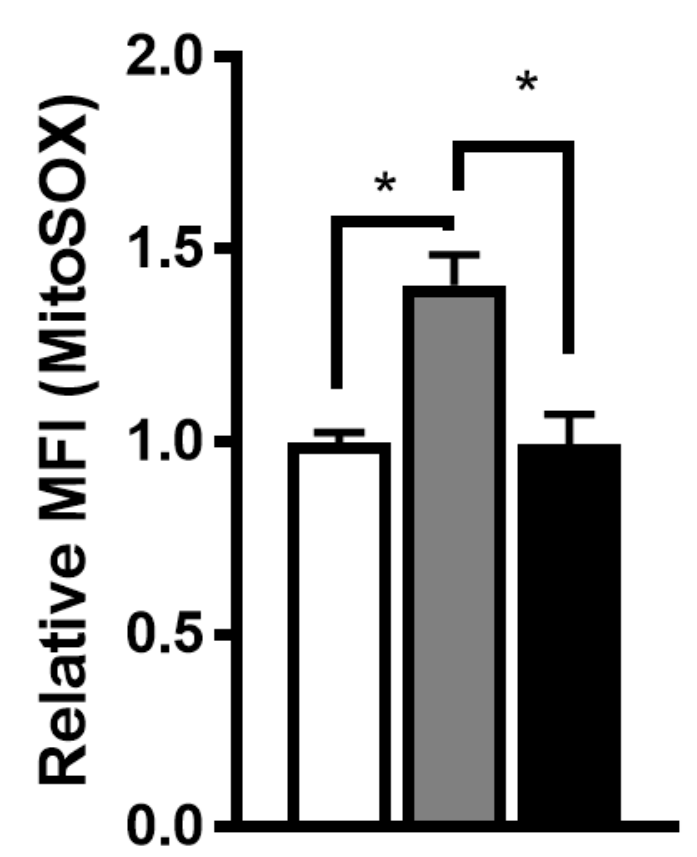

C

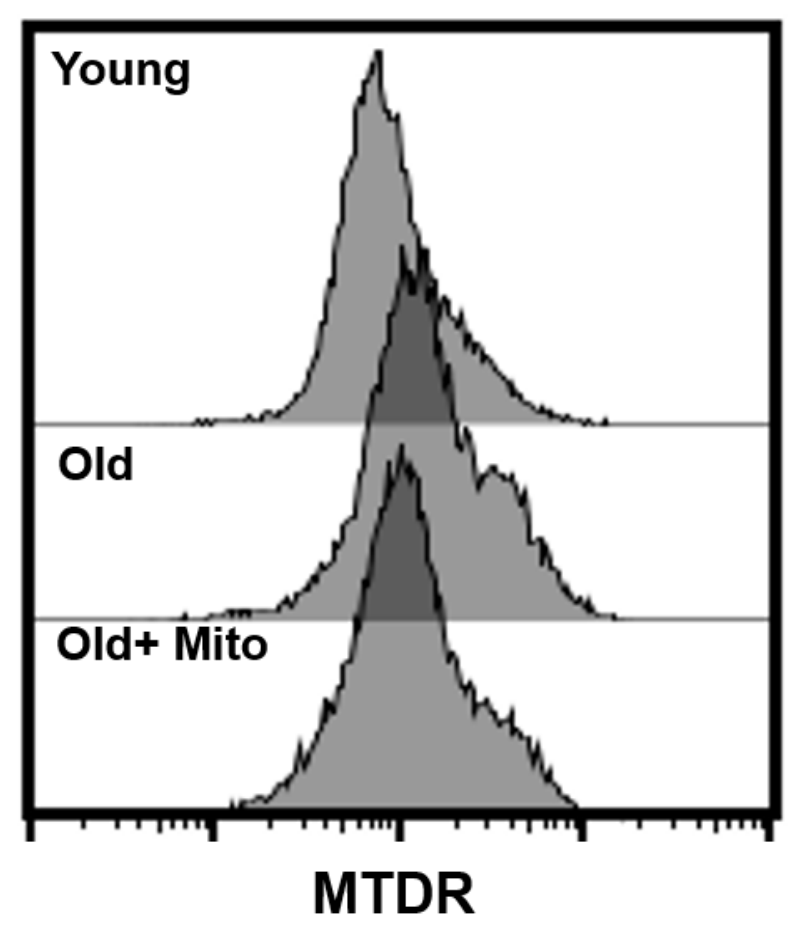

G
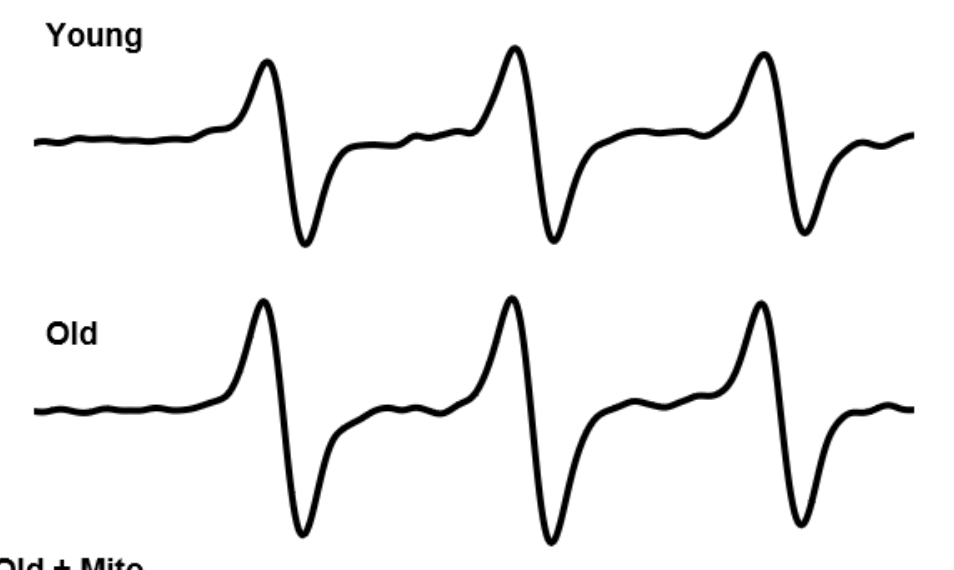

Old + Mito

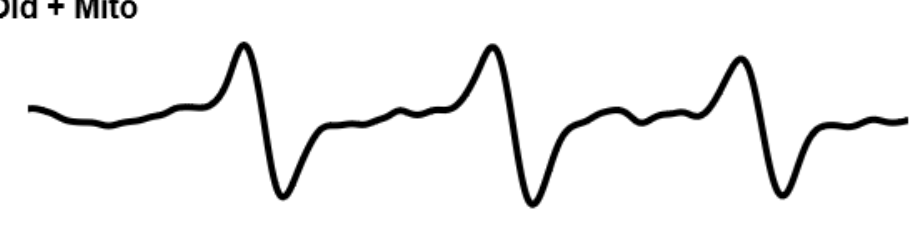

3400
D

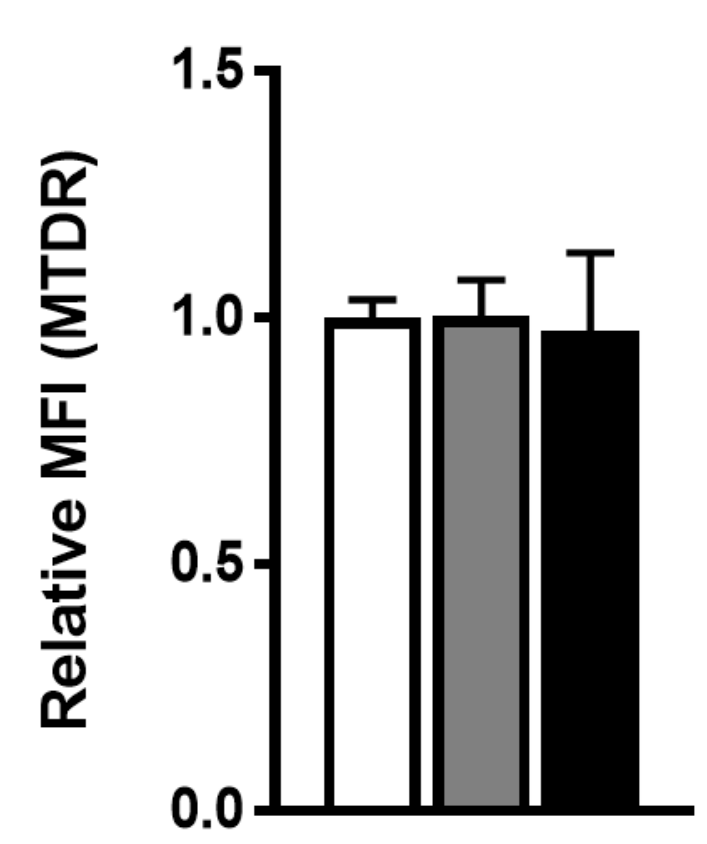

H

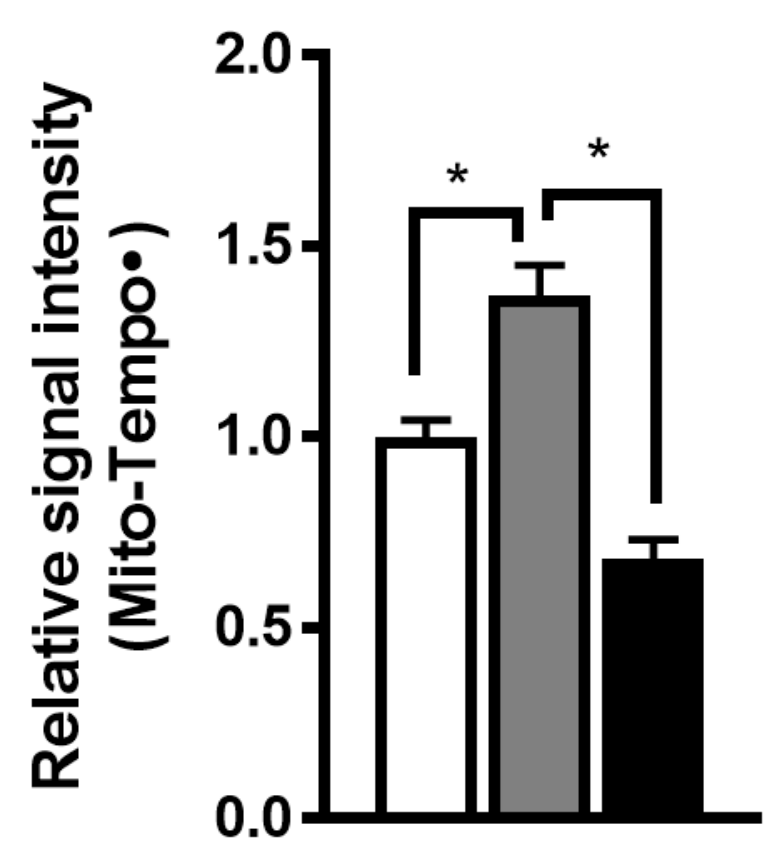

Fig. 3. 
Fig 3. Mitochondrial transfer reduces mitochondrial ROS production in $\mathrm{CD4}^{+} \mathrm{T}$ cells from old mice. Relative MFI of A-B) MTV-G, C-D) MTDR and E-F) MitoSOX of CD4 ${ }^{+}$T cells from young and old mice, $\mathrm{CD} 4^{+} \mathrm{T}$ cells from old mice after mito-transfer. G) EPR spectrum and $\mathbf{H}$ ) bar graphs of $\mathrm{CD}^{+}{ }^{+} \mathrm{T}$ cells probed with Mito-Tempo-H. 4-5 mice were used per group and all experiments were at least replicated $(n=2), p<0.05=$ significant $\left(^{*}\right)$ using unpaired Student's $t$-test. 
A

$\begin{array}{llllll}01 & 02 & 03 & \text { OM1 OM2 OM3 }\end{array}$

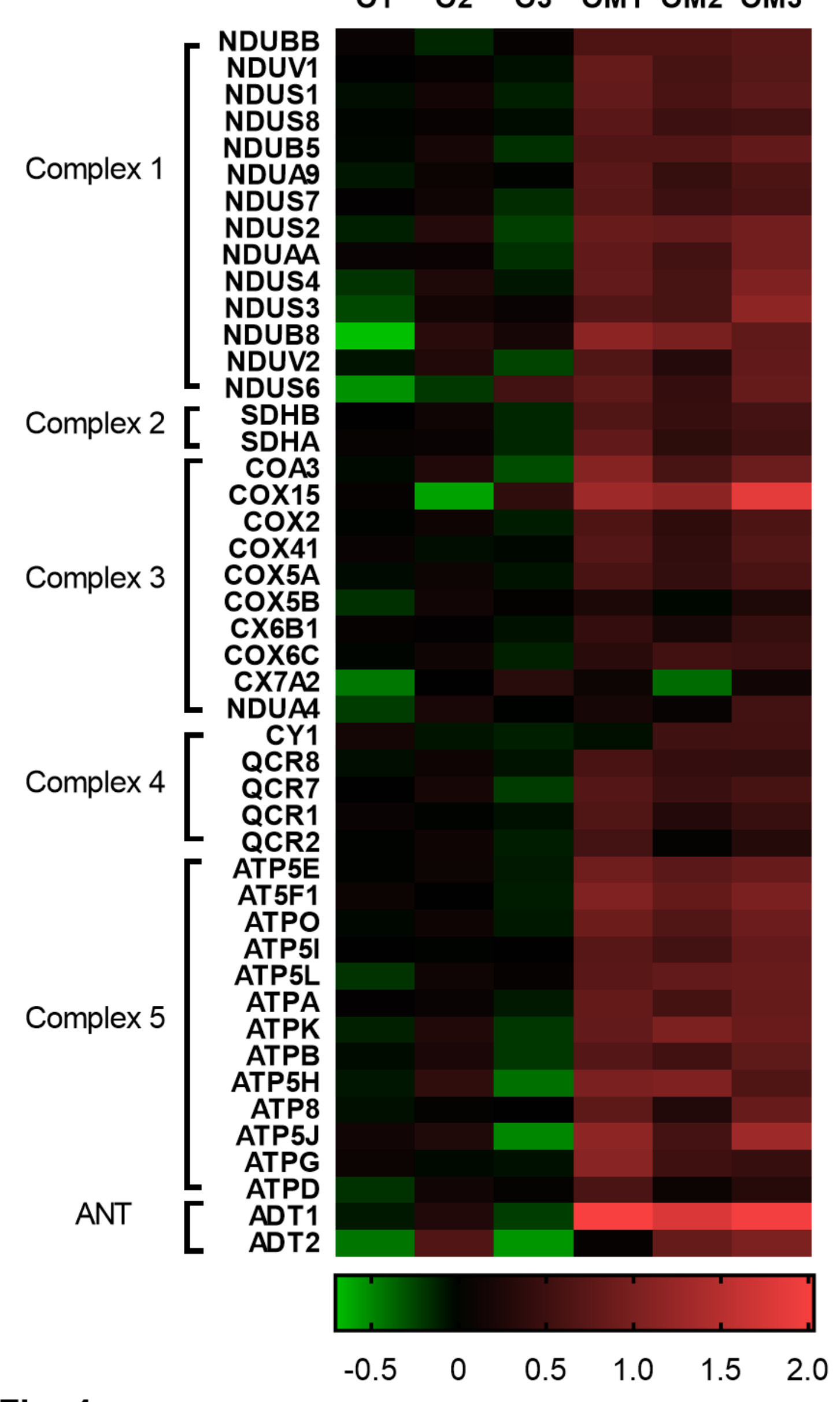

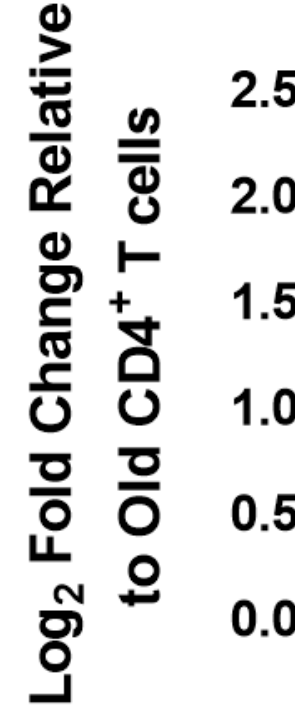

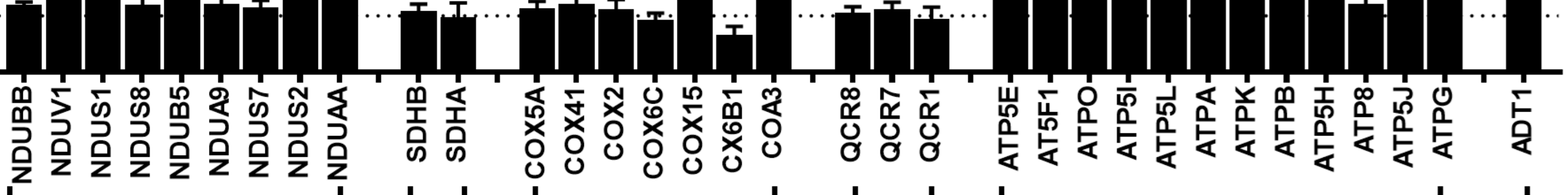
항

C

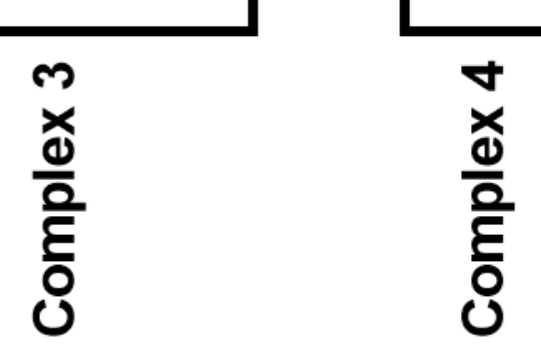

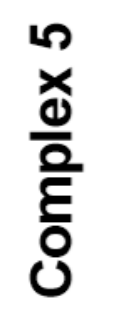
妾 D

E

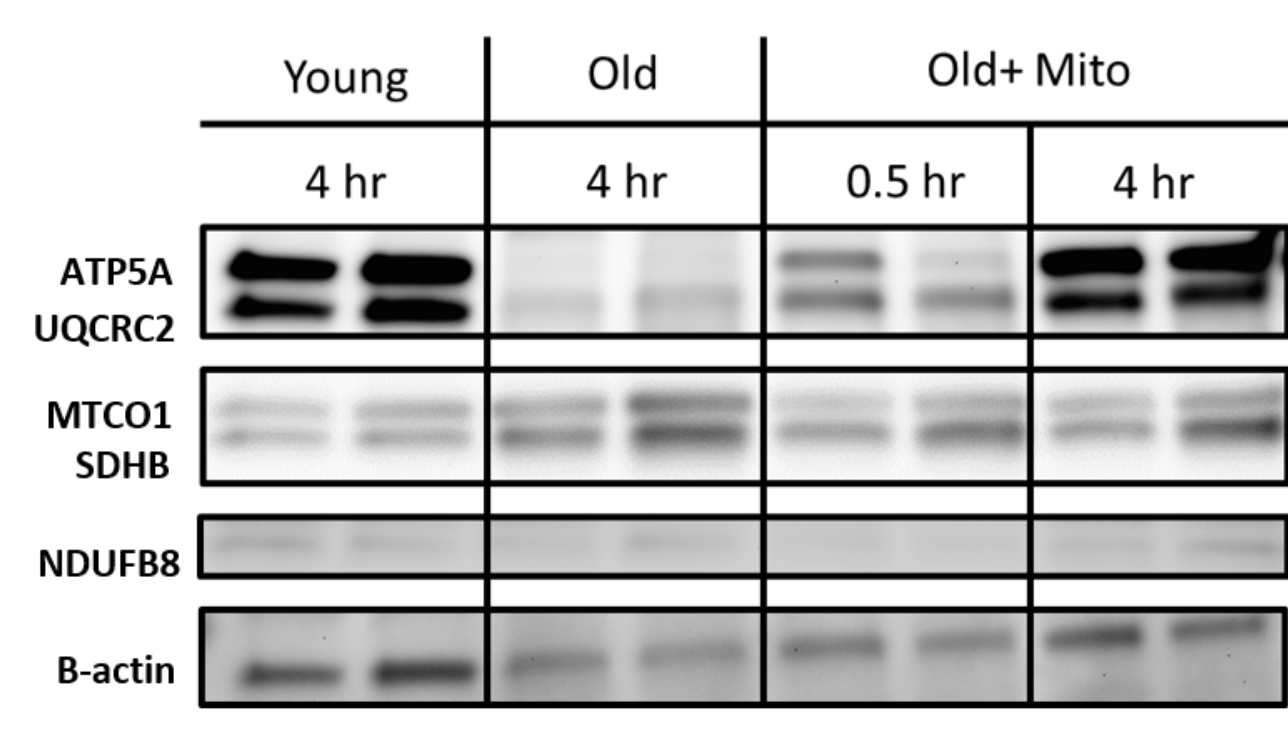

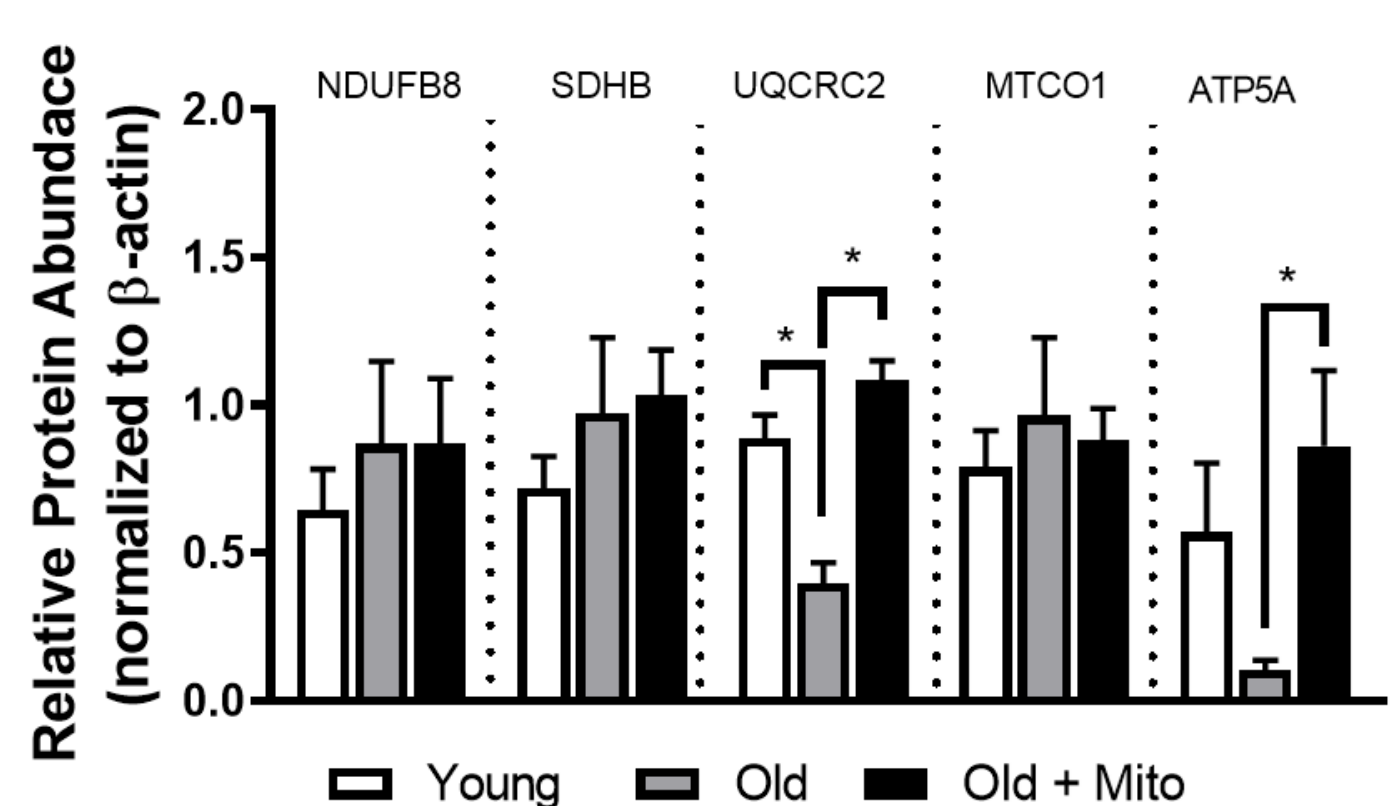

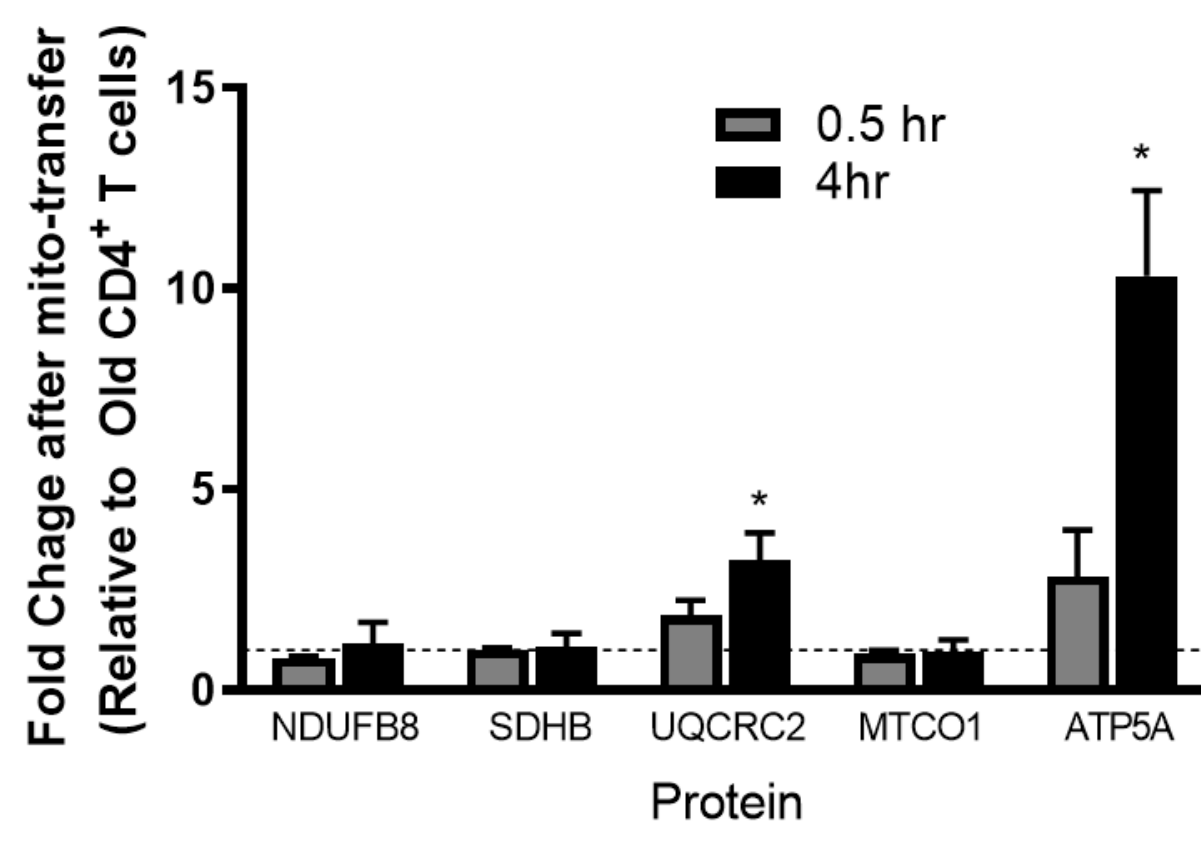


Fig 4. Mito-transfer increased intracellular mitochondrial complex proteins in CD4 ${ }^{+}$T cells from old mice. A) Heatmap of proteins related to the electron transport chain (ETC) in CD4 ${ }^{+} \mathrm{T}$ cells from old mice with and without mito-transfer. B) Fold change of significantly upregulated proteins, C) Western blot bands, D) Relative protein abundance in CD4+ $\mathrm{T}$ cells isolated from young and old mice, and CD4 ${ }^{+} \mathrm{T}$ cells from old mice $4 \mathrm{~h}$ after mito-transfer, E) Fold change in ETC proteins in $\mathrm{CD}^{+} \mathrm{T}$ cells from old mice at 30 mins and $4 \mathrm{~h}$ after mito-transfer. Proteomic experiments were performed once with 3 mice/group and internaly normalized to $\beta$-actin. $p<0.05$ $=$ significant $\left(^{*}\right)$ using paired and unpaired Students $t$-test. 


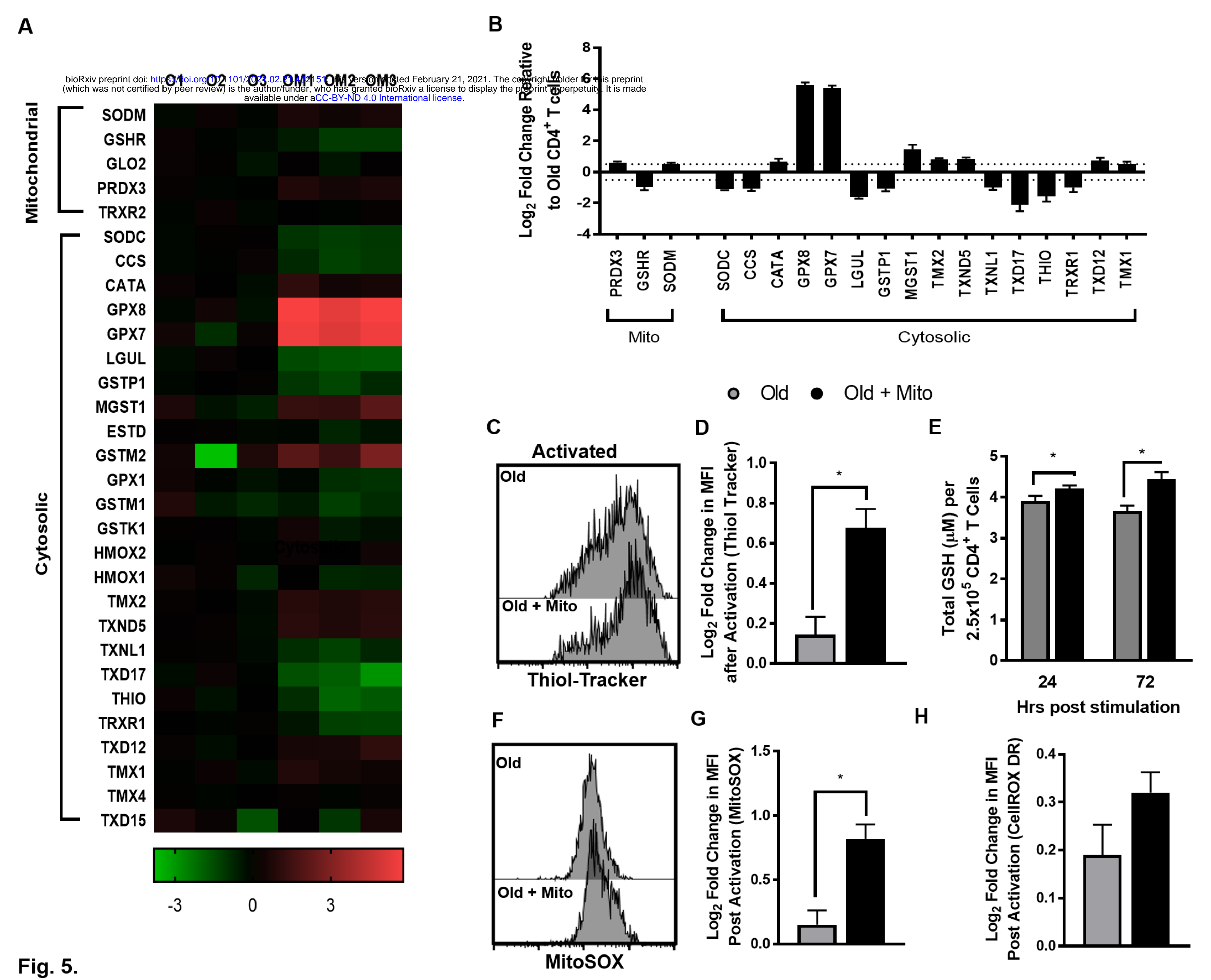


Fig 5. Antioxidant proteins are downregulated in old CD4 T cells post mito-transfer. A) Heatmap of antioxidant proteins in old CD4 T cells before and after mito transfer. B) Fold change in antioxidant proteins significantly downregulated or upregulated post mito transfer. C) Representative histograms of old $\mathrm{CD} 4^{+} \mathrm{T}$ cells from old mce with or without mito-transfer and after stimulation with PMA/ionomycin for 4 h. D) Log2 Fold change in MFI of thioltracker in CD4 T cells after mito-transfer and PMA/ionomycin stimulation (4h). E) Total GSH of CD4 T cells at 24 and $72 \mathrm{~h}$ post stimulation with PMA/lonomycin. Log2 Fold change in MFI of F-G) MitoSOX and $\mathbf{H}$ ) CellROX in CD4 T cells from old mice with or without mito-transfer, and PMA/ionomycin stimulation (4h). proteomic experiments were performed once with 3 mice per group $(n=1)$. Flow based experiments for the detection of thiols and ROS were duplicated with 4-5 mice/group $(\mathrm{n}=$ 2), microplate-based detection or thiols were triplicated with 4 mice/group $(n=3)$. $p<0.05=$ significant $\left(^{*}\right)$ using paired student's $t$-test. 
A $\quad \circ$ Old $\bullet$ Old + Mito

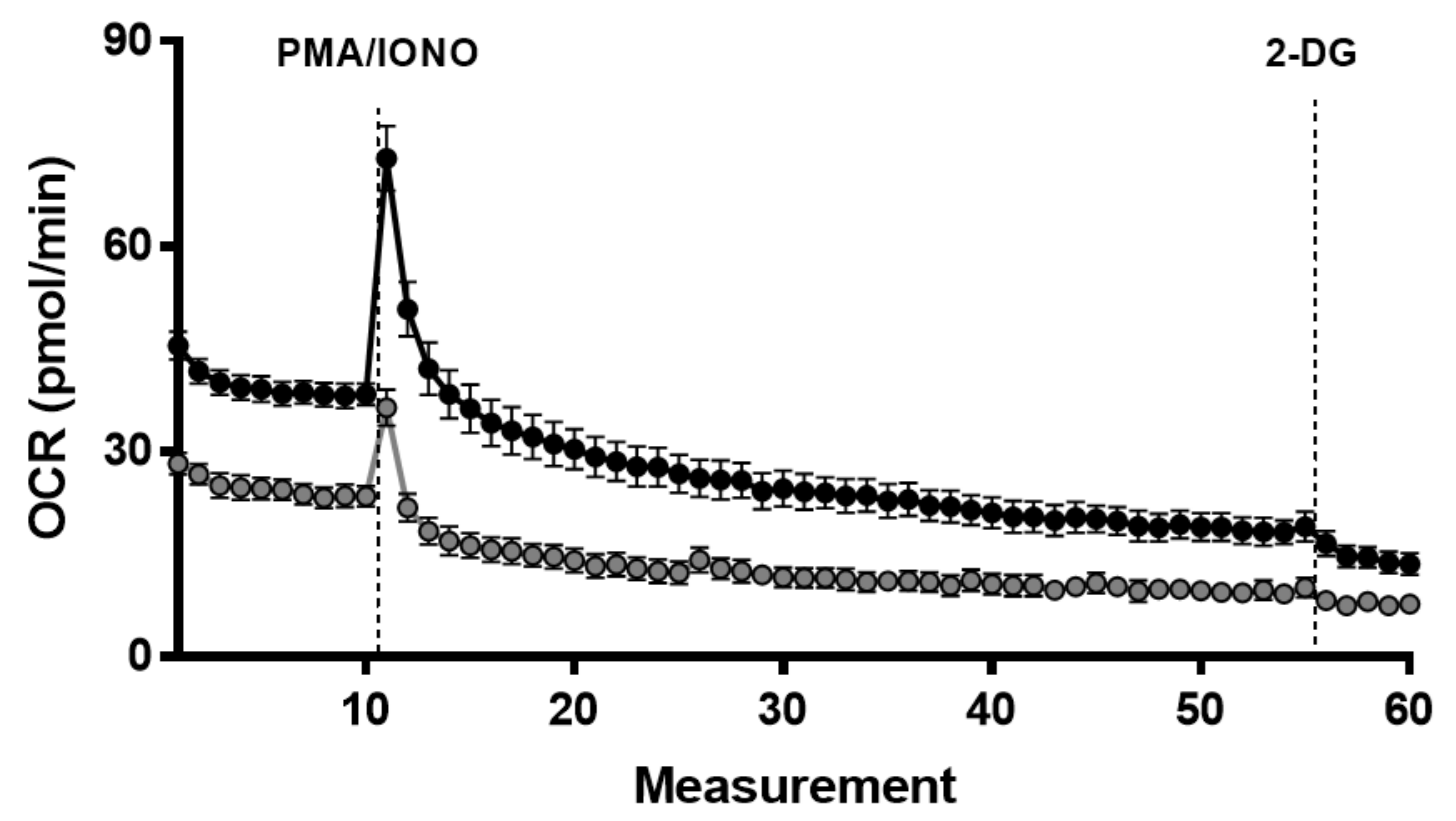

C

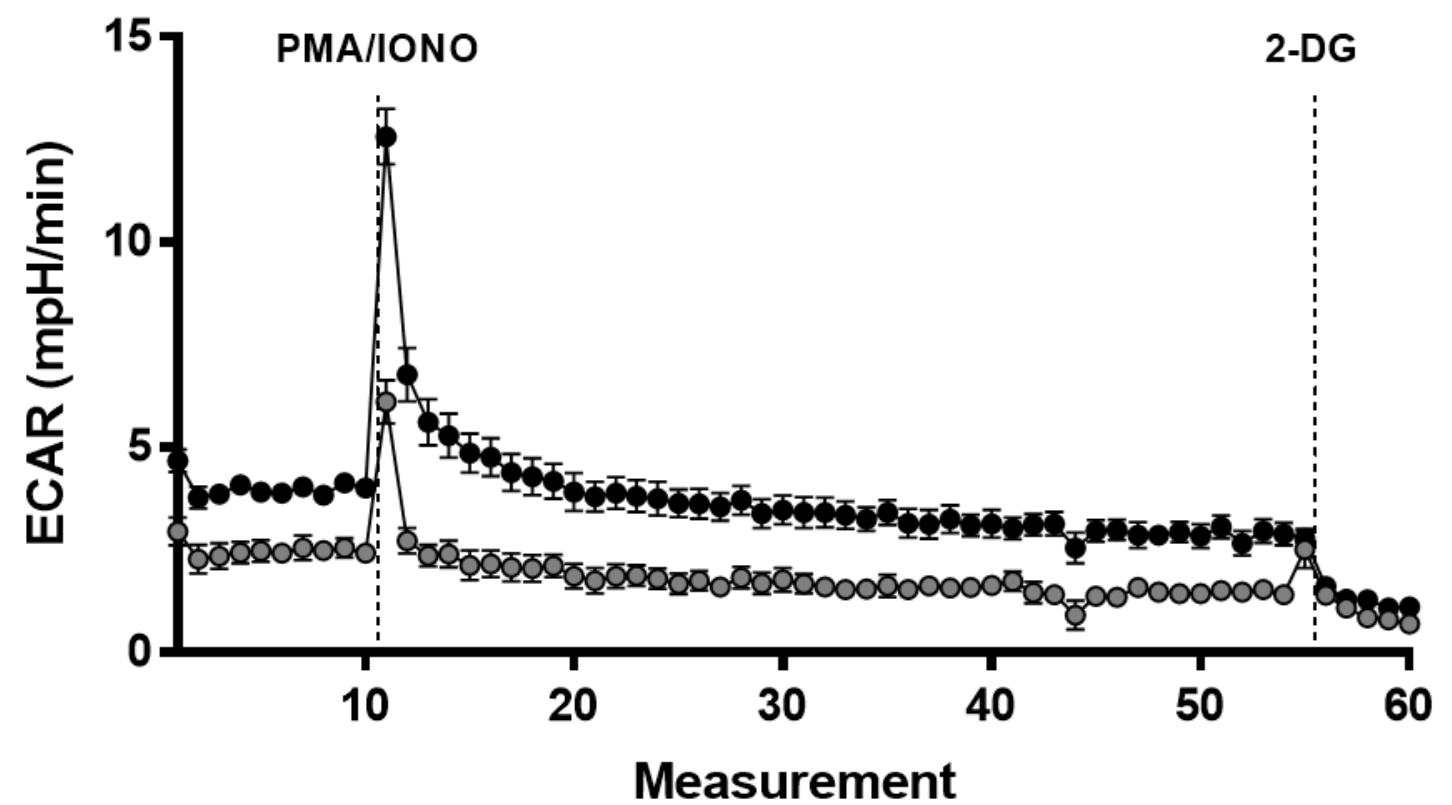

B

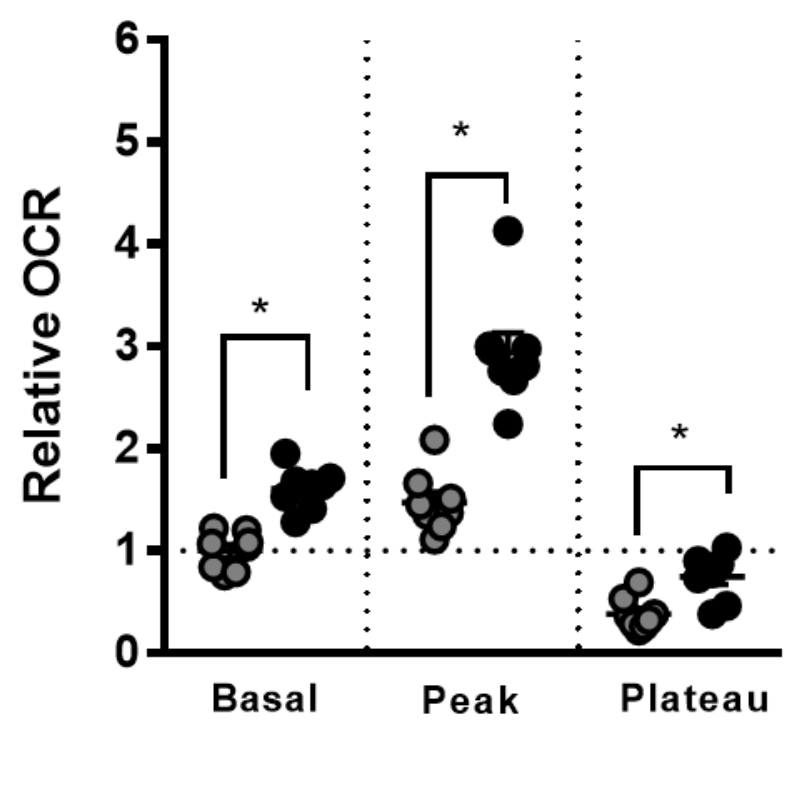

D

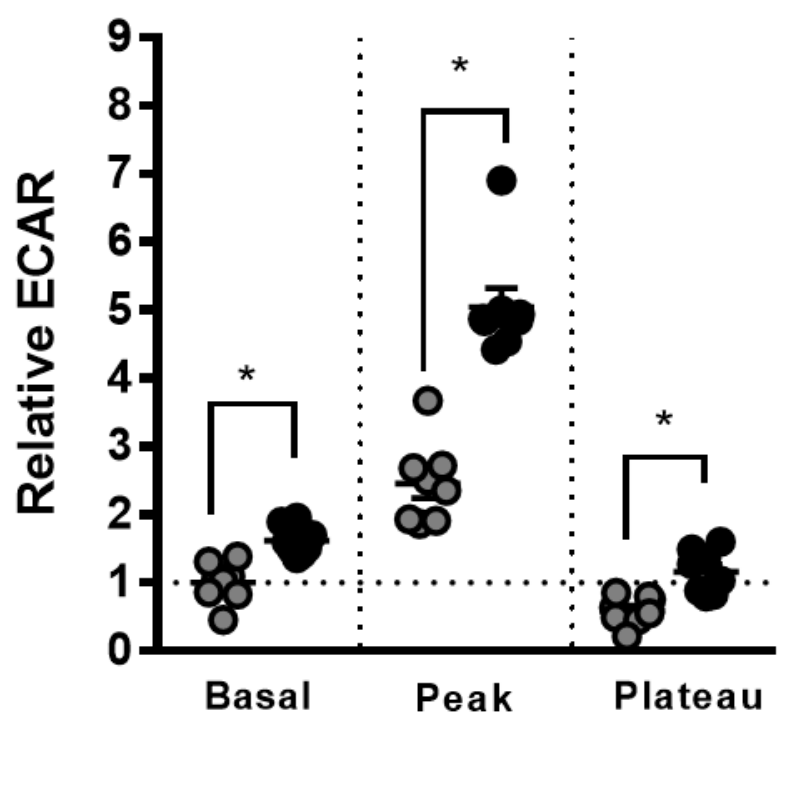

Fig. 6. 
Fig 6. Mito-transfer enhances activation induced switch from Ox-Phos to aerobic glycolysis in $\mathrm{CD4}^{+} \mathrm{T}$ cells from old mice. CD4 ${ }^{+} \mathrm{T}$ cells $\left(2.5 \times 10^{5}\right)$ were plated onto Poly-D-lysine coated 96 well microplates, after which $\mathrm{O}_{2}$ consumption (OCR) and extracellular acidification rates (ECAR) were measured under basal conditions and in response to acute injection of PMA/IONO. A) Representative OCR kinetic graph B) Relative basal, peak and plateau OCR measurements normalized to basal OCR of old CD4+ $\mathrm{T}$ cells. C) Representative ECAR kinetic graph. D) Relative basal, peak and plateau ECAR measurements normalized to basal ECAR of old CD4+ ${ }^{+}$cells. Experiments were duplicated with 4 mice/group $(n=2), p<0.05=$ significant $\left({ }^{*}\right)$ using paired student's $t$-test. 

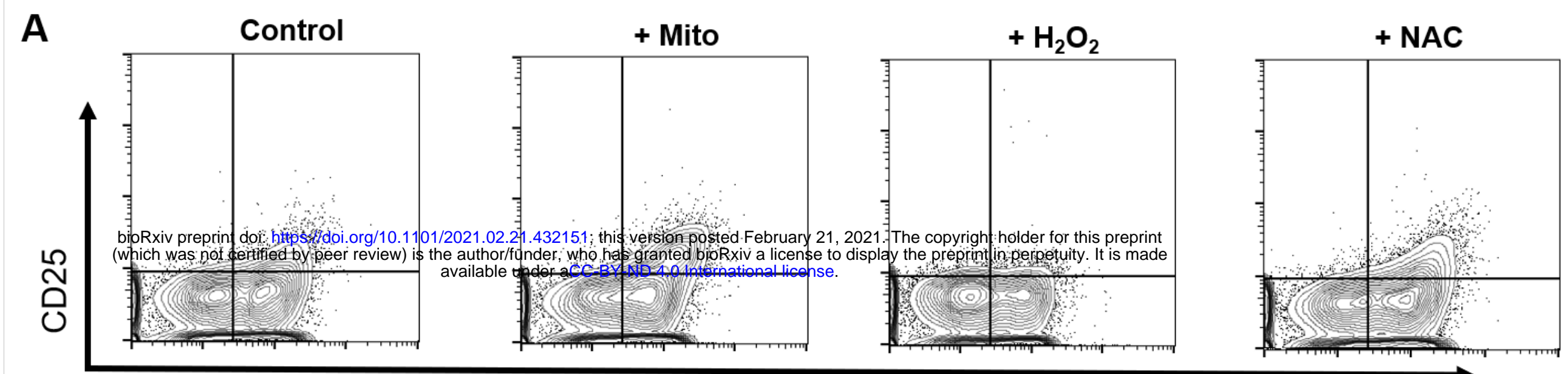

\section{CD69}

B

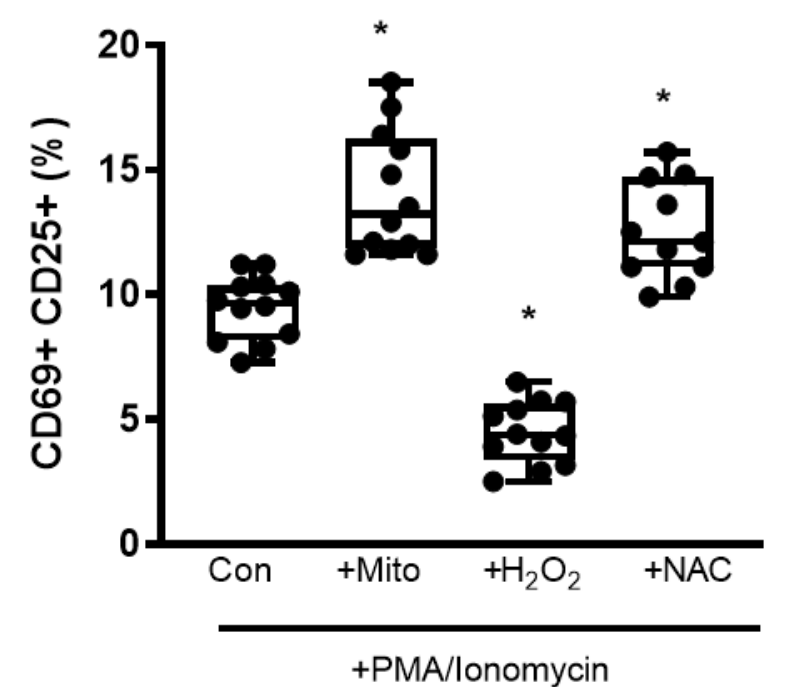

E

H

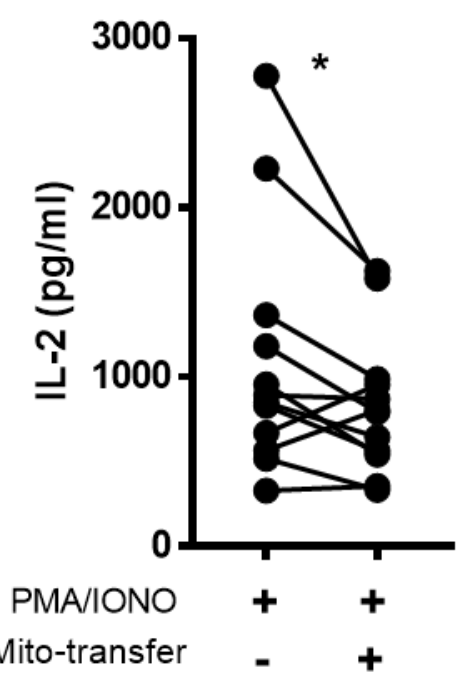

C

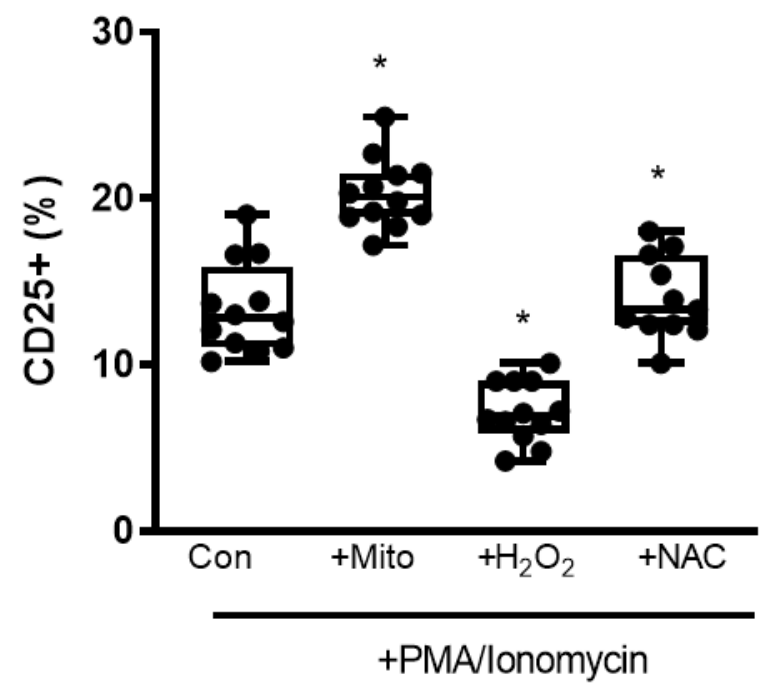

F

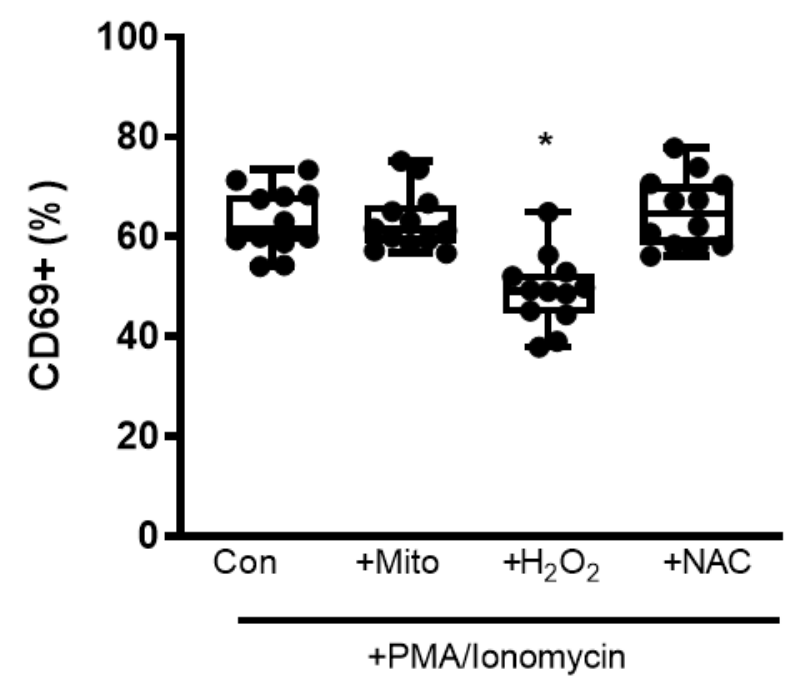

G
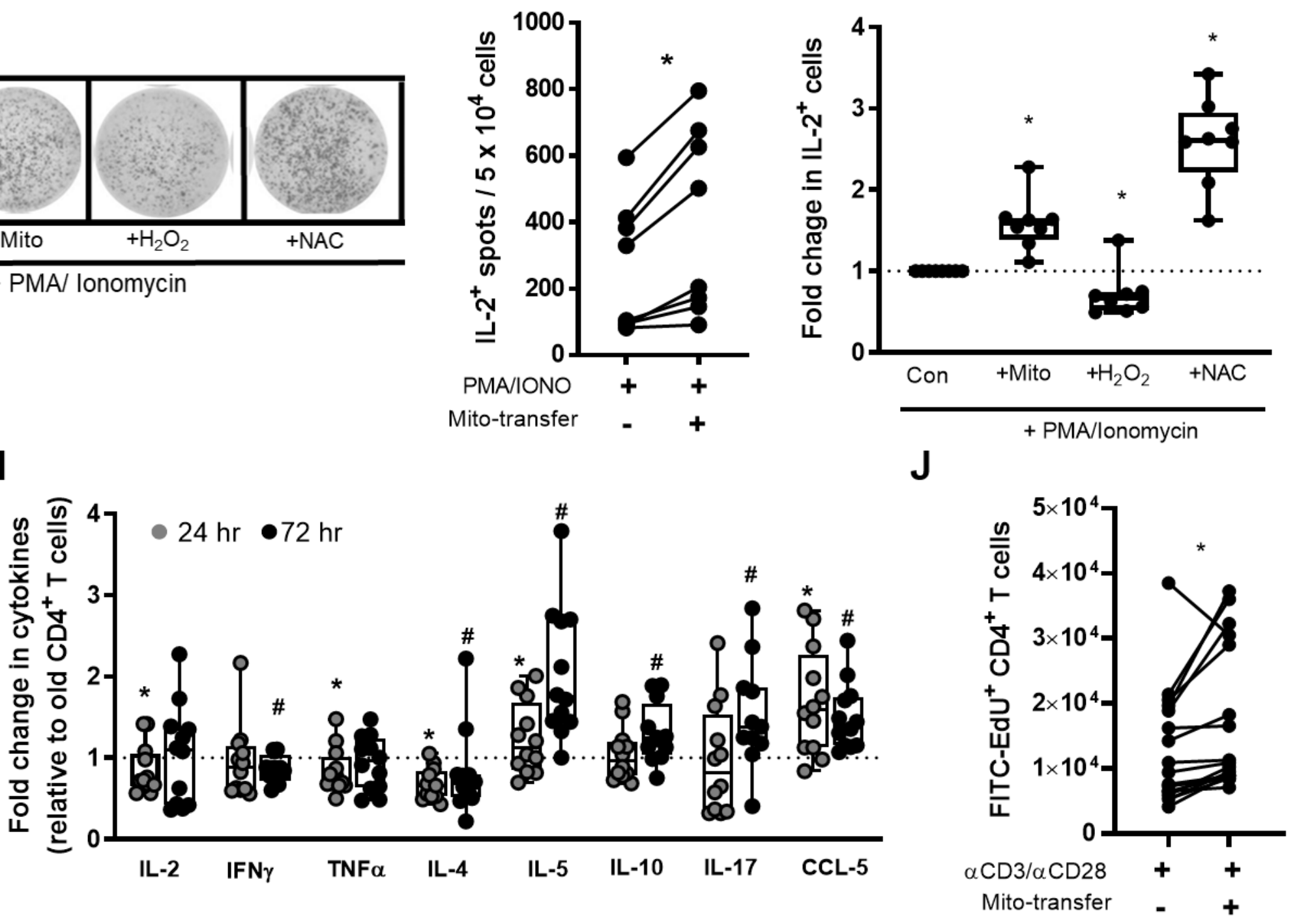

Fig. 7. 
Fig. 7. Mitochondrial transfer increased CD25+ and CD25+CD69+ expression on $\mathrm{CD}^{+}{ }^{+} \mathrm{T}$ cells after activation. CD4 ${ }^{+} \mathrm{T}$ cells from old mice were stimulated with $\mathrm{PMA} /$ lonomycin for $24 \mathrm{~h}$ either under pro-oxidant, antioxidant, or after mito-transfer. A) Contour plots of CD25 v CD69 expression on $\mathrm{CD}^{+}{ }^{+} \mathrm{T}$ cells, percent of $\mathrm{CD}^{+}{ }^{+} \mathrm{T}$ cells positive for B) CD25CD69, C) CD25 and, D) CD69 after $24 \mathrm{~h}$ PMA/lonomycin stimulation. E) Representative EliSpot wells, F) paired comparison of IL-2+ $\mathrm{CD}^{+} \mathrm{T}$ cells from old mice with or without mito-transfer and after stimulation with PMA/lonomycin (24hr), G) fold change in IL-2+ CD4+ $\mathrm{T}$ cells under various antioxidant and pro-oxidant conditions or after mito-transfer. H) Paired comparison of soluble IL-2 in the media of CD4+ ${ }^{+}$cells with or without mito-transfer, and after they were stimulated with PMA/lonomycin (24hr). I) Relative levels of cytokines in the media of mito-transferred $\mathrm{CD} 4^{+} \mathrm{T}$ cells compared to non-manipulated $\mathrm{CD}^{+} \mathrm{T}$ cells from old mice at 24 and $72 \mathrm{~h}$ post activation. $\mathrm{K}) \mathrm{EdU}+\mathrm{CD}^{+} \mathrm{T}$ cells paired comparison after $72 \mathrm{~h}$ stimulation in the presence of $\alpha C D 3 / \alpha C D 28$. All experiments were at least done twice $(n=2)$, $\mathrm{p}<0.05=$ significant $\left({ }^{*},{ }^{\#}\right)$ using ratio paired $t$-test $(\mathrm{A}-\mathrm{H}, \mathrm{J})$ or paired $t$-test $(\mathrm{I})$. 
A $\triangle$ Young $\odot$ Old

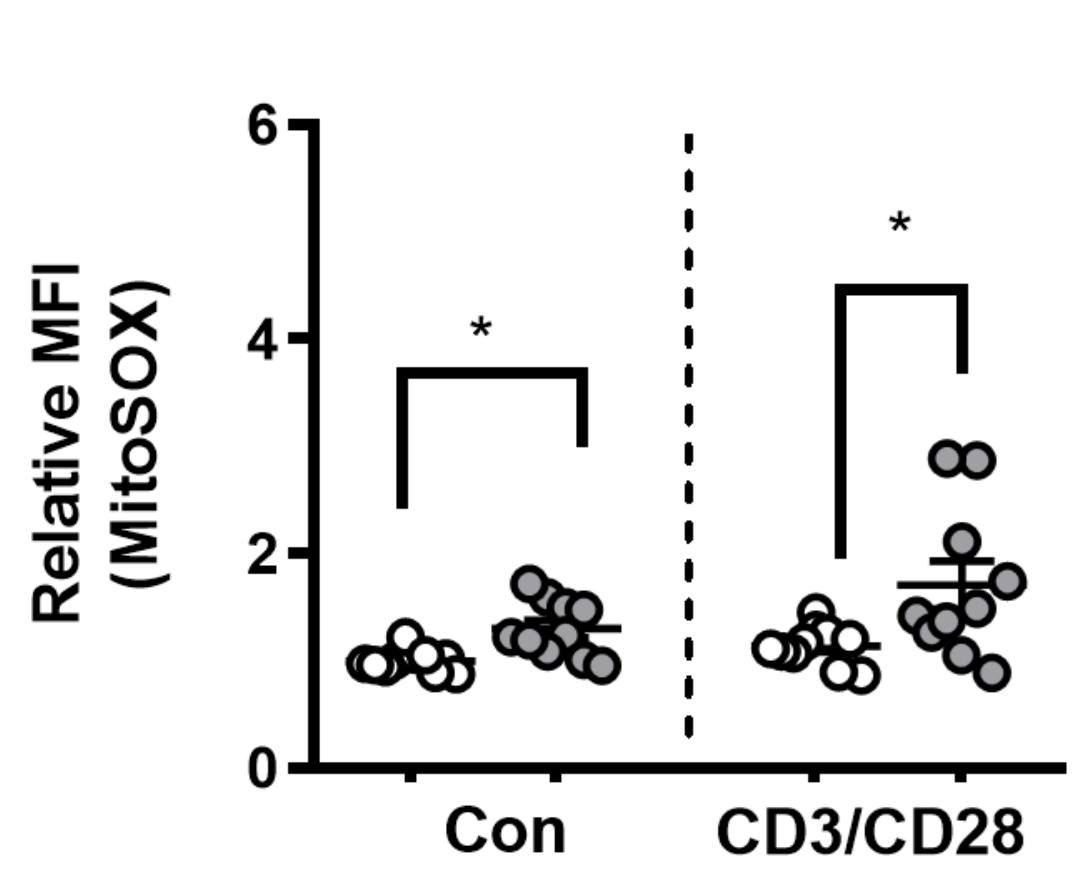

B

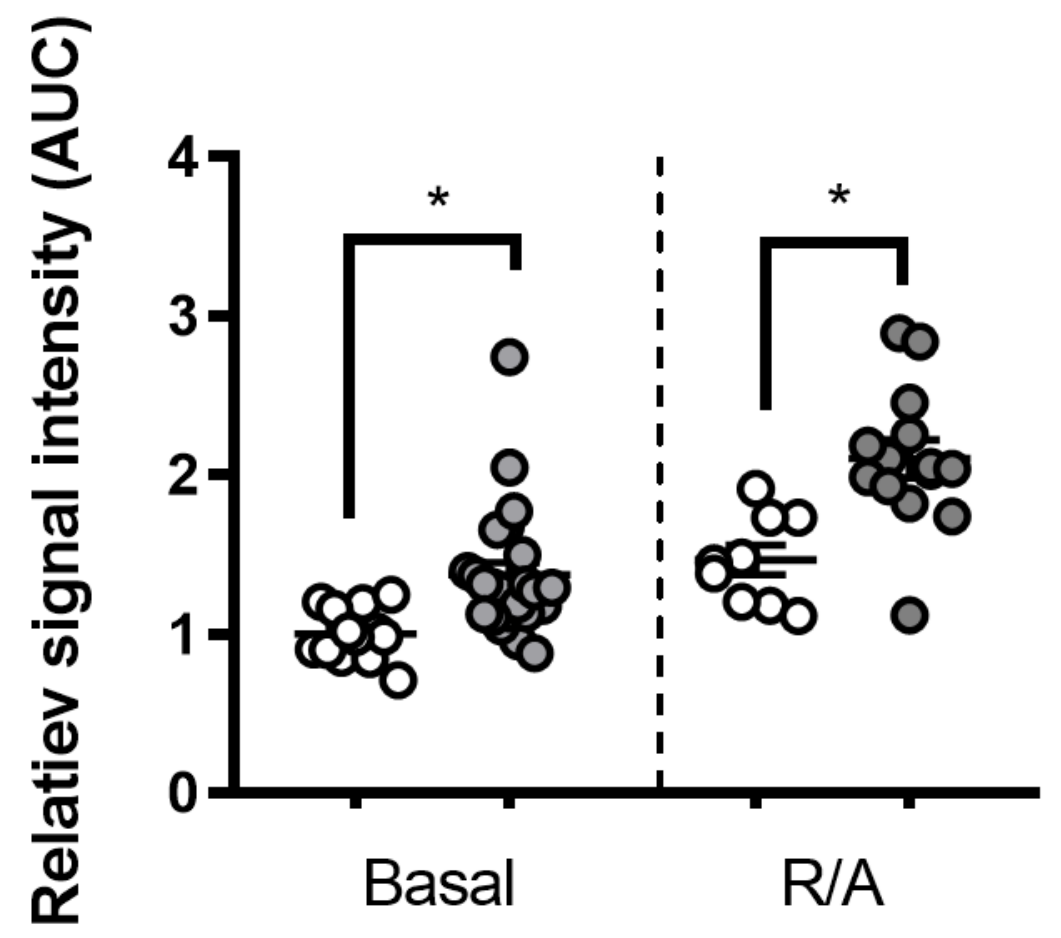

Supp. Fig. 1. 
Supp. Fig. 1 MitoROS in increased in $\mathrm{CD}^{+} \mathrm{T}$ cells isolated from old mice. $\mathrm{CD} 4^{+} \mathrm{T}$ cells isolated from young and old mice were either activated or cultured in the presence of oxidative stress inducers (Rotenone/Antimicin A), prior to MitoSOX staining and quantitation via flow cytometry or EPR spectroscopy. A) Relative MFI of MitoSOX of $\mathrm{CD4}^{+} \mathrm{T}$ cells isolated from young and old BALB/c mice after activation with CD3/CD28. B) Relative intensity of Mito-tempo* in CD4+ T cells isolated from young and old C57BL/6 mice under basal or oxidative stress conditions. ( $\mathrm{n}$ $=2) \cdot p<0.05=$ significant $\left({ }^{*}\right)$ using unpaired Student's $t$-test. 
A

-o Young o- Old - Old + Mito

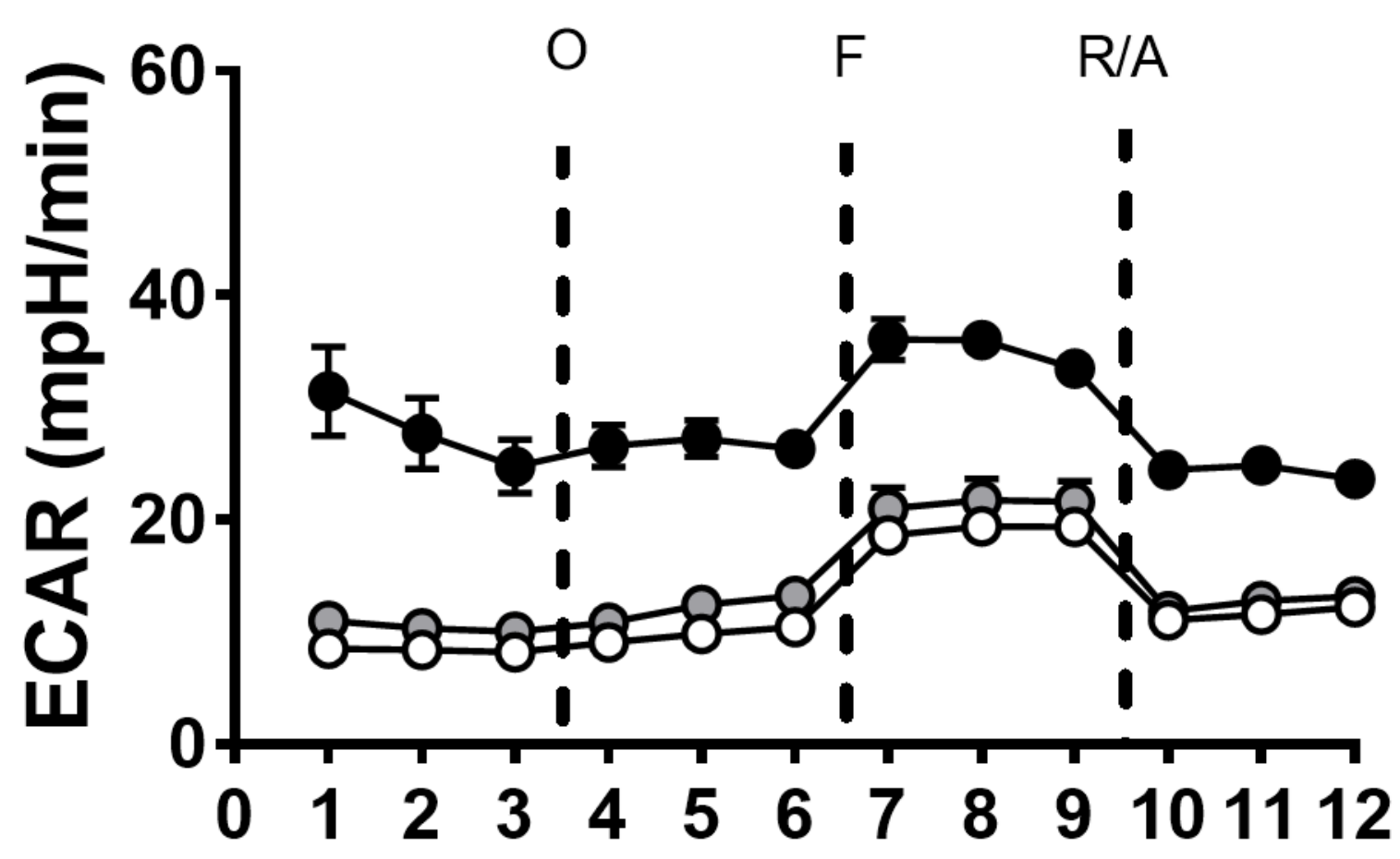

Measurement

C

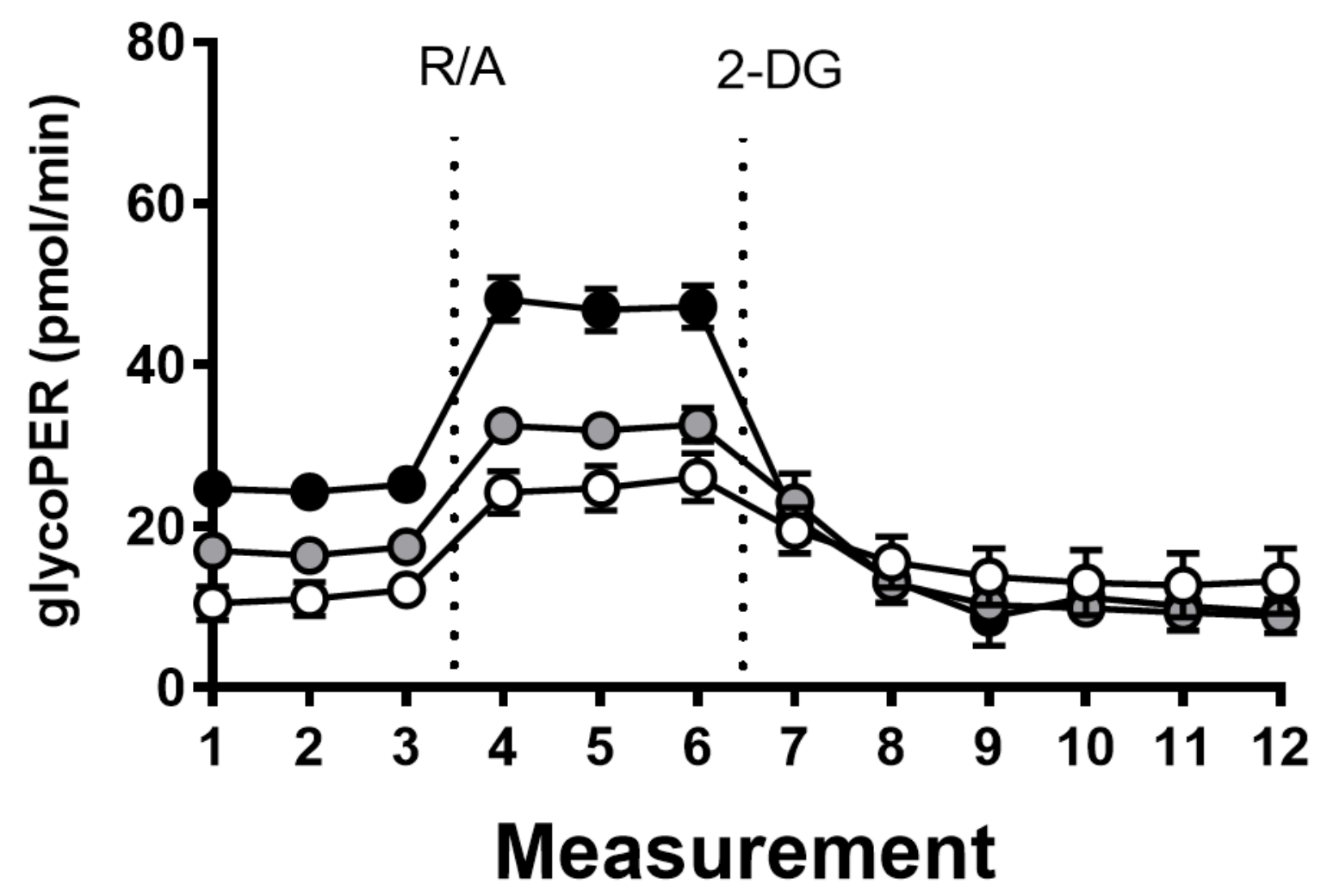

B

Basal

Max

Resp.

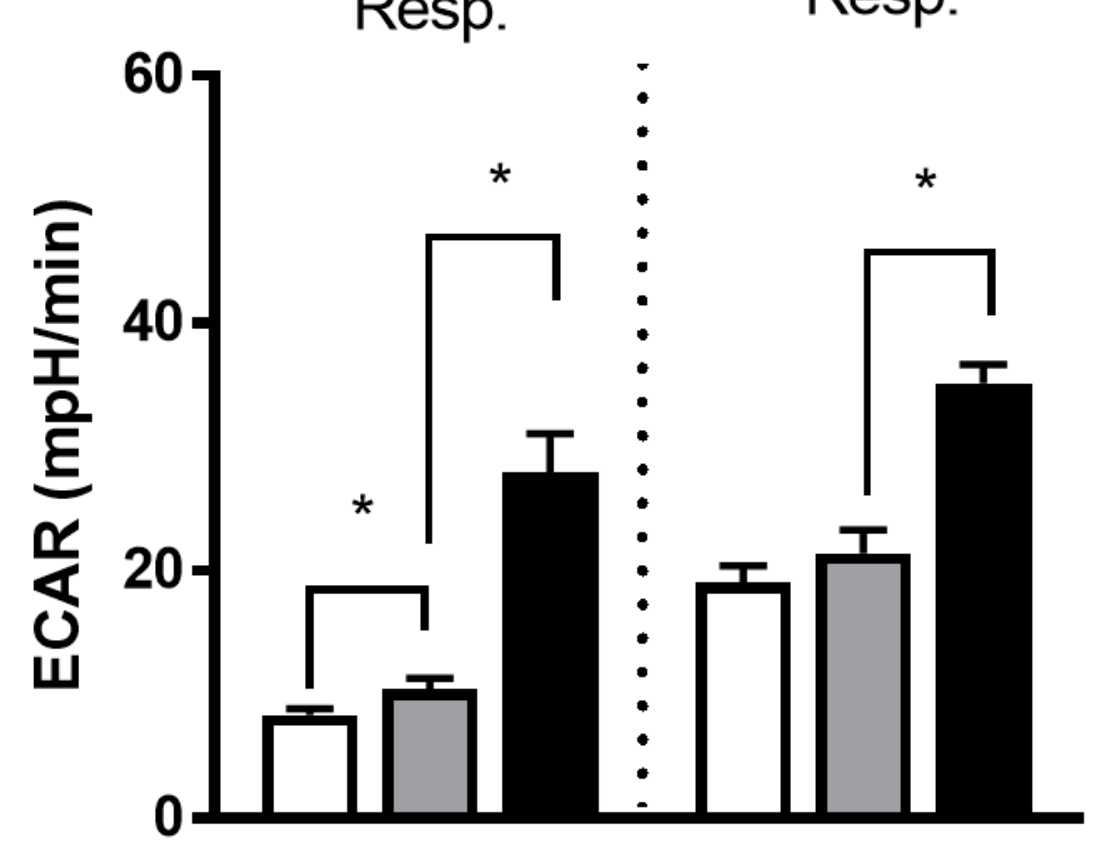

D

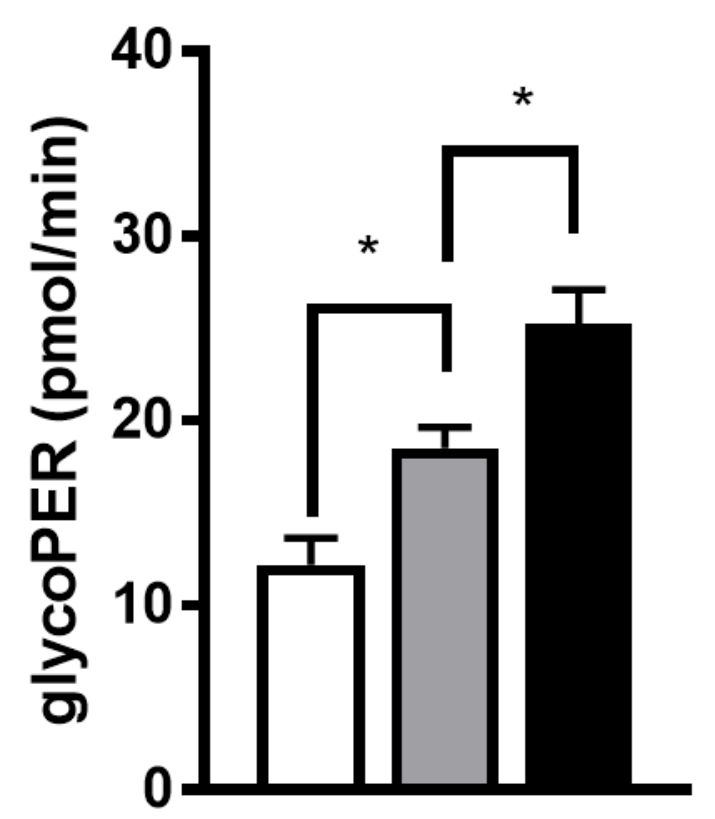

Supp. Fig. 2. 
Supp. Fig 2. ECAR of CD4+ T cells from old mice increases after mito-transfer. A) Kinetic curve of ECAR collected from mito-stress test assay, B) ECAR corresponding to basal and maximal respiration of $\mathrm{CD}^{+} \mathrm{T}$ cells. C) Kinetic curve glycolys flux assay and D) GlycoPER of CD4 ${ }^{+} T$ cells cells. 3-4 mice were used per group and experiments were replicated twice $(n=3)$, $p<0.05=$ significant $\left({ }^{*}\right)$ using unpaired Student's t-test. 
A
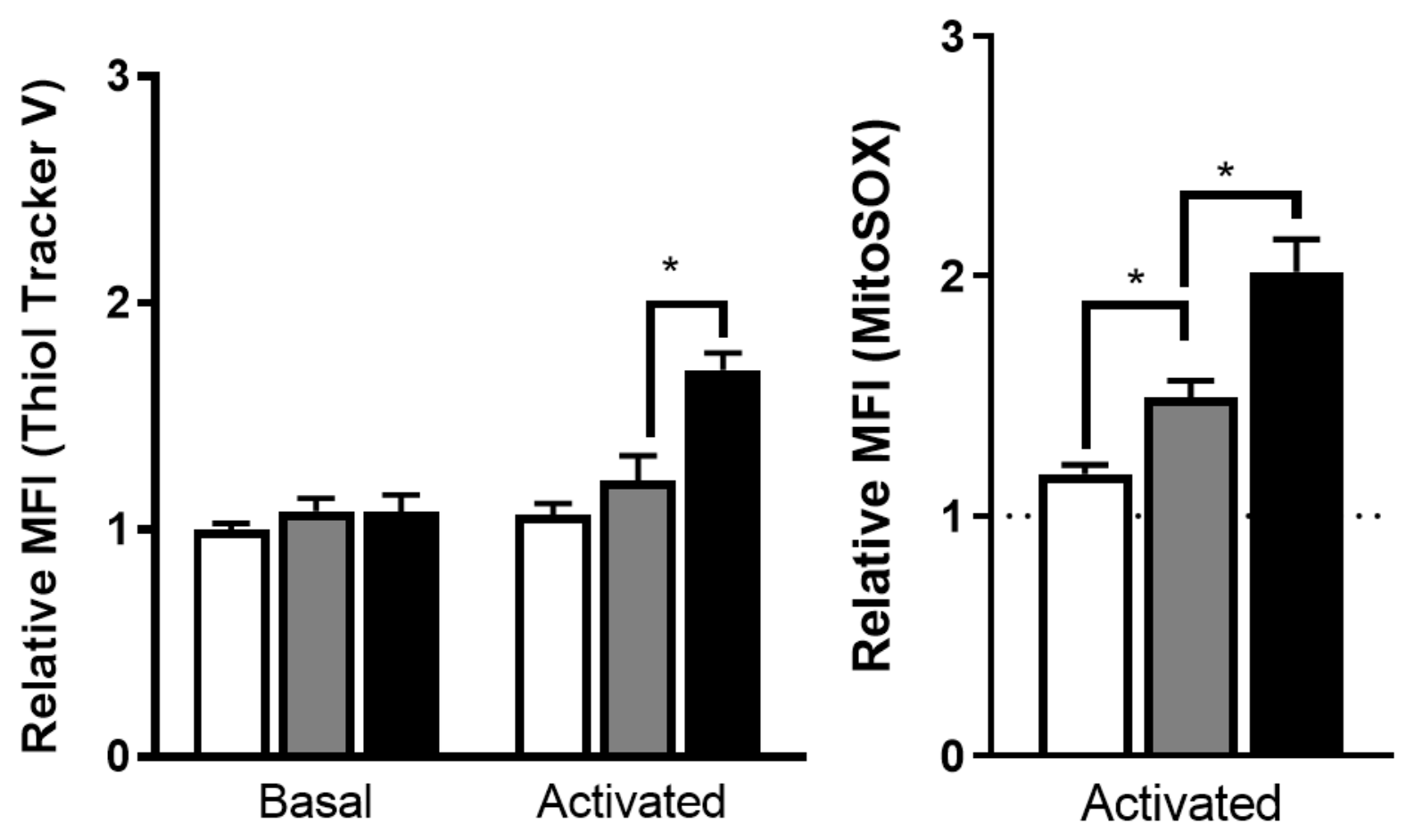

E Young

ㅁold

- Old + Mito

Supp. Fig. 3. 


\section{Supp. Fig 3. Relative MFI of Thiol tracker Violet and MitoSOX in CD4+ ${ }^{+}$cells. CD4+T cells} isolated from young and old mice, and $\mathrm{CD}^{+}{ }^{+} \mathrm{T}$ cells isolated from old mice that received mitotransfer were stained with A) ThiolTracker to detect intracellular thiols and B) MitoSOX to detect mitoROS after stimulation with PMA/lonomycin. MFI values were normalized to the MFI of CD4 ${ }^{+}$ T cells isolated from young mice from each individual experiment. 4 mice were used per group and all experiments were duplicated $(n=2), p<0.05=$ significant $\left(^{*}\right)$ using unpaired or paired student's $t$-test. 
$\rightarrow$ Old $\rightarrow$ Old +Mito

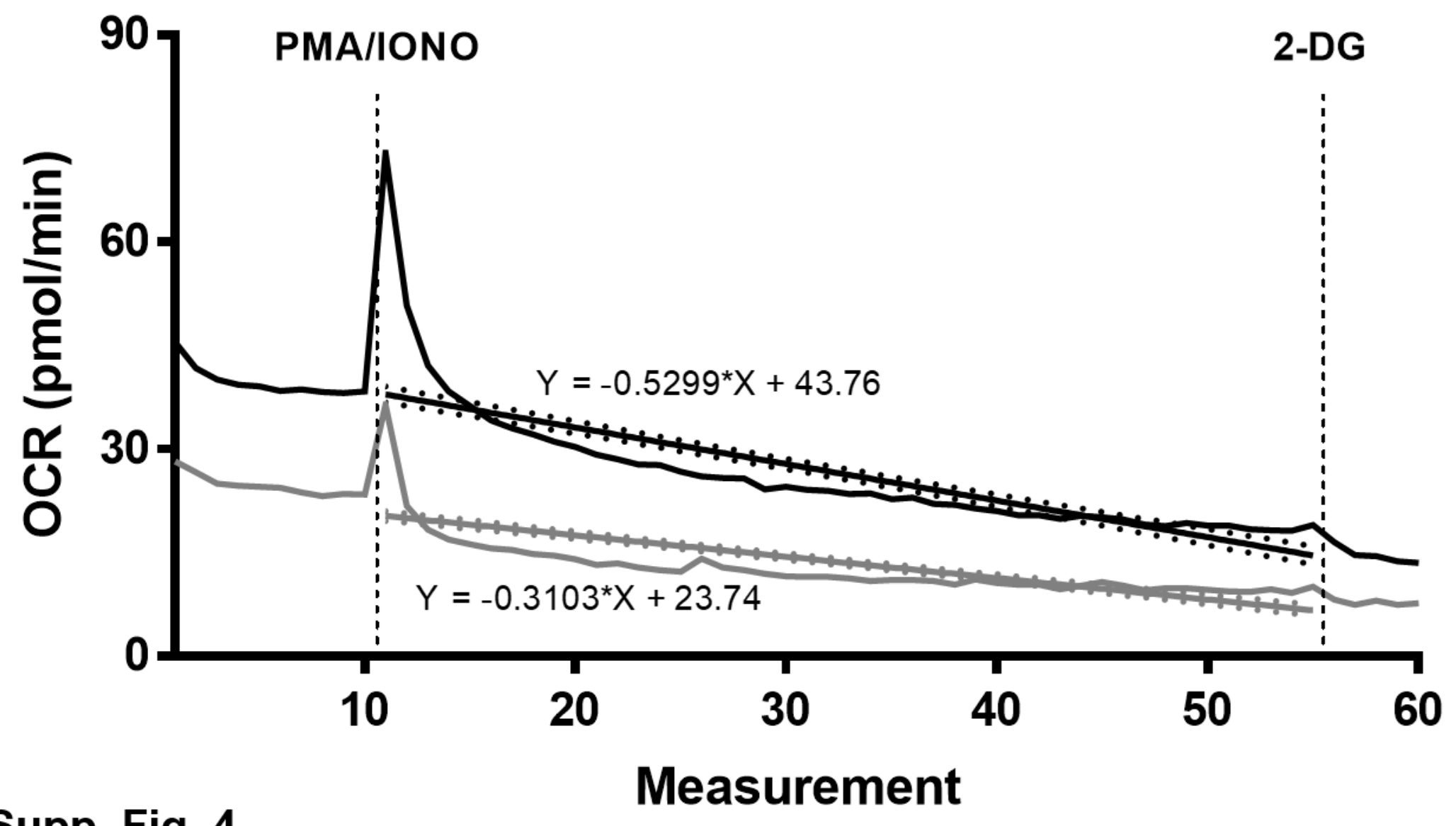

Supp. Fig. 4. 
bioRxiv preprint doi: https://doi.org/10.1101/2021.02.21.432151; this version posted February 21, 2021. The copyright holder for this preprint (which was not certified by peer review) is the author/funder, who has granted bioRxiv a license to display the preprint in perpetuity. It is made available under aCC-BY-ND 4.0 International license.

\section{Supp. Fig. 4. Slope of OCR depression after acute injection of PMA/IONO in mito-} transferred and non-manipulated $\mathrm{CD}^{+}{ }^{+} \mathrm{T}$ cells from old mice. The slopes were determined in graphpad prism software using the linear regression function, starting from the point of PMA injection and ending at the point of 2-DG injection. 
A

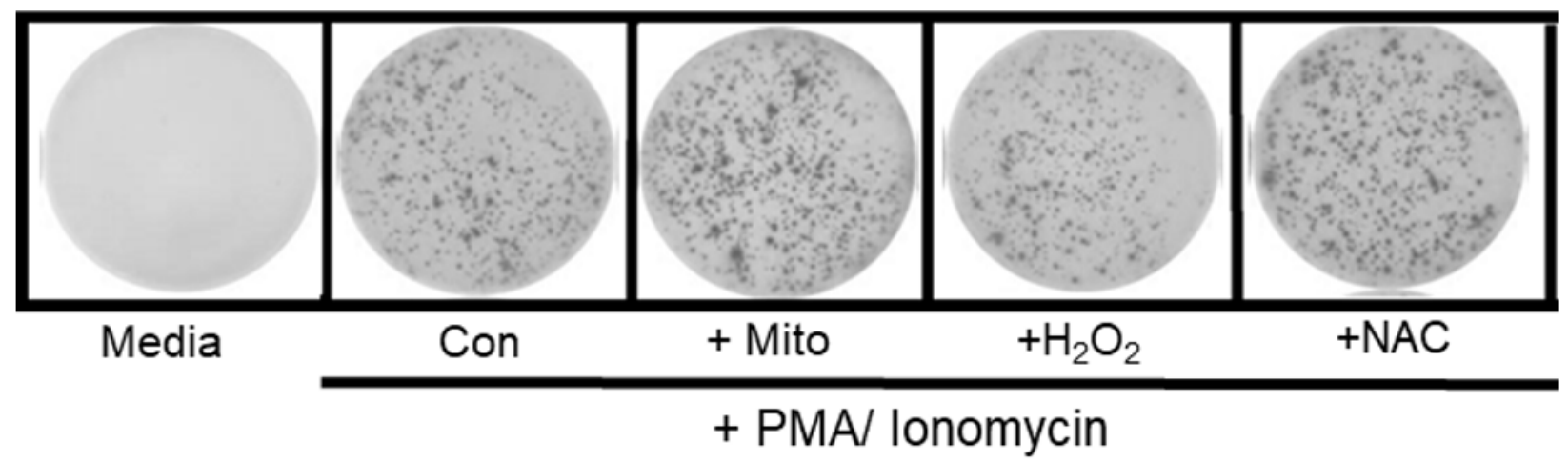

B

C
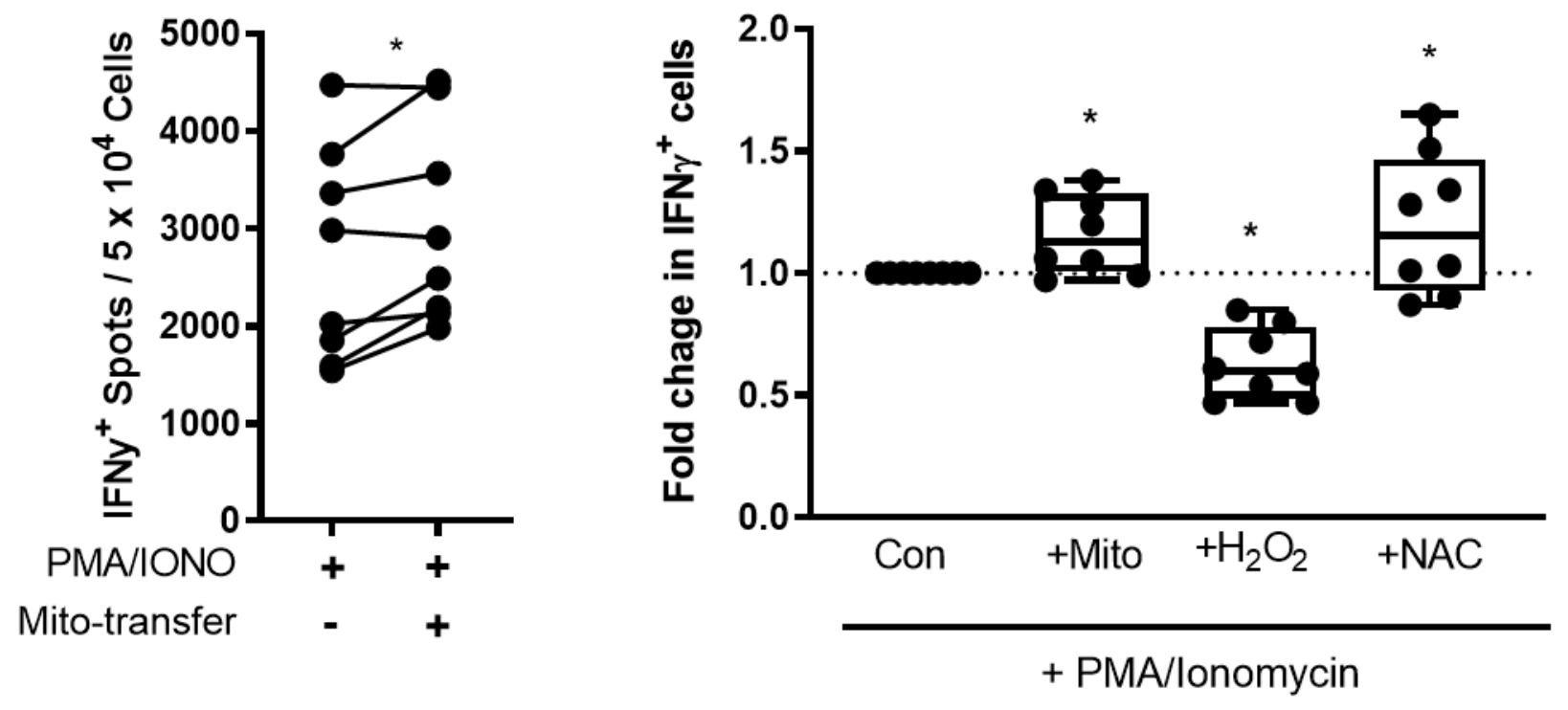

Supp. Fig. 5. 
Supp. Fig. 5. Impact of mito-transfer on IF $\mathrm{N \gamma}^{+} \mathrm{CD} 4^{+} \mathrm{T}$ cells from old mice. $\mathrm{CD} 4^{+} \mathrm{T}$ cells were activated for $24 \mathrm{hr}$ either under pro-oxidant, antioxidant conditions, or after mito-transfer. A) Representative EliSpot wells, B) paired comparison of IFNy ${ }^{+}$cells in non-manipulated $\mathrm{CD}^{+} \mathrm{T}$ cells and $\mathrm{CD} 4^{+} \mathrm{T}$ cells after mito-transfer and stimulation with PMA/lonomycin (24hr), and C) fold change in IFNy ${ }^{+} \mathrm{CD}^{+}+$cells. 3-4 mice per group, repeated once $(n=2) . \quad p<0.05=$ significant $\left({ }^{*}\right)$ using paired student's $t$-test. 
bioRxiv preprint doi: https://doi.org/10.1101/2021.02.21.432151; this version posted February $21,2021$. The copyright holder for this preprint (which was not certified by peer review) is the author/funder, who has granted bioRxiv a license to display the preprint in perpetuity. It is made available under aCC-BY-ND 4.0 International license.

\begin{tabular}{|c|c|c|c|c|c|c|c|c|}
\hline Protein & 01 & 02 & 03 & OM1 & OM2 & OM3 & P. value & FDR \\
\hline NDUBB & 0.075 & -0.140 & 0.056 & 0.634 & 0.631 & 0.704 & 0.001 & 0.018 \\
\hline NDUV1 & 0.013 & 0.047 & -0.062 & 0.830 & 0.566 & 0.701 & 0.001 & 0.019 \\
\hline NDUS1 & -0.048 & 0.149 & -0.114 & 0.799 & 0.600 & 0.737 & 0.002 & 0.025 \\
\hline NDUS8 & -0.019 & 0.062 & -0.045 & 0.727 & 0.484 & 0.533 & 0.002 & 0.025 \\
\hline NDUB5 & -0.024 & 0.178 & -0.175 & 0.658 & 0.659 & 0.787 & 0.003 & 0.032 \\
\hline NDUA9 & -0.084 & 0.090 & -0.012 & 0.729 & 0.430 & 0.624 & 0.004 & 0.037 \\
\hline NDUS7 & 0.020 & 0.130 & -0.164 & 0.703 & 0.486 & 0.594 & 0.005 & 0.040 \\
\hline NDUS2 & -0.114 & 0.292 & -0.232 & 0.832 & 0.800 & 0.922 & 0.006 & 0.045 \\
\hline NDUAA & 0.075 & 0.085 & -0.174 & 0.793 & 0.535 & 0.935 & 0.006 & 0.047 \\
\hline NDUS4 & -0.190 & 0.239 & -0.084 & 0.797 & 0.576 & 1.040 & 0.012 & 0.067 \\
\hline NDUS3 & -0.267 & 0.156 & 0.077 & 0.673 & 0.582 & 1.150 & 0.021 & 0.090 \\
\hline NDUB8 & -0.706 & 0.328 & 0.179 & 1.137 & 0.975 & 0.775 & 0.039 & 0.132 \\
\hline NDUV2 & -0.070 & 0.272 & -0.252 & 0.648 & 0.293 & 0.786 & 0.049 & 0.154 \\
\hline NDUS6 & -0.534 & -0.209 & 0.530 & 0.758 & 0.417 & 0.831 & 0.095 & 0.237 \\
\hline SDHB & 0.002 & 0.128 & -0.142 & 0.649 & 0.435 & 0.554 & 0.005 & 0.042 \\
\hline SDHA & 0.064 & 0.066 & -0.140 & 0.786 & 0.361 & 0.518 & 0.017 & 0.081 \\
\hline COA3 & -0.036 & 0.267 & -0.284 & 1.080 & 0.575 & 0.868 & 0.002 & 0.028 \\
\hline COX15 & 0.042 & -0.596 & 0.388 & 1.286 & 1.141 & 1.851 & 0.004 & 0.038 \\
\hline COX2 & -0.016 & 0.113 & -0.105 & 0.630 & 0.375 & 0.627 & 0.007 & 0.048 \\
\hline COX41 & 0.074 & -0.051 & -0.026 & 0.685 & 0.396 & 0.669 & 0.008 & 0.052 \\
\hline COX5A & -0.039 & 0.100 & -0.067 & 0.590 & 0.415 & 0.590 & 0.015 & 0.075 \\
\hline COX5B & -0.174 & 0.131 & 0.027 & 0.231 & -0.028 & 0.243 & 0.015 & 0.076 \\
\hline CX6B1 & 0.046 & 0.017 & -0.066 & 0.423 & 0.191 & 0.426 & 0.017 & 0.080 \\
\hline C0X6C & -0.019 & 0.129 & -0.121 & 0.339 & 0.523 & 0.485 & 0.192 & 0.384 \\
\hline CX7A2 & -0.441 & 0.015 & 0.325 & 0.104 & -0.393 & 0.140 & 0.219 & 0.419 \\
\hline NDUA4 & -0.223 & 0.201 & -0.009 & 0.186 & 0.064 & 0.531 & 0.287 & 0.512 \\
\hline CY1 & 0.169 & -0.074 & -0.111 & -0.058 & 0.513 & 0.523 & 0.957 & 1.000 \\
\hline QCR8 & -0.050 & 0.115 & -0.072 & 0.587 & 0.420 & 0.414 & 0.004 & 0.038 \\
\hline QCR7 & 0.010 & 0.184 & -0.222 & 0.679 & 0.459 & 0.564 & 0.013 & 0.069 \\
\hline QCR1 & 0.070 & -0.011 & -0.062 & 0.649 & 0.281 & 0.453 & 0.015 & 0.076 \\
\hline QCR2 & -0.012 & 0.112 & -0.109 & 0.543 & 0.034 & 0.299 & 0.140 & 0.306 \\
\hline ATP5E & -0.014 & 0.102 & -0.095 & 0.901 & 0.740 & 0.844 & 0.000 & 0.013 \\
\hline AT5F1 & 0.090 & 0.009 & -0.106 & 1.050 & 0.819 & 0.996 & 0.000 & 0.014 \\
\hline ATPO & -0.023 & 0.106 & -0.090 & 0.881 & 0.650 & 0.877 & 0.001 & 0.019 \\
\hline ATP5I & 0.007 & -0.015 & 0.008 & 0.716 & 0.531 & 0.811 & 0.001 & 0.020 \\
\hline ATP5L & -0.190 & 0.128 & 0.043 & 0.727 & 0.807 & 0.842 & 0.001 & 0.022 \\
\hline ATPA & 0.019 & 0.069 & -0.093 & 0.823 & 0.559 & 0.828 & 0.002 & 0.025 \\
\hline ATPK & -0.118 & 0.276 & -0.205 & 0.806 & 1.012 & 0.850 & 0.005 & 0.040 \\
\hline ATPB & -0.042 & 0.216 & -0.205 & 0.681 & 0.526 & 0.765 & 0.009 & 0.057 \\
\hline ATP5H & -0.081 & 0.385 & -0.417 & 0.990 & 1.034 & 0.638 & 0.025 & 0.101 \\
\hline ATP8 & -0.056 & 0.039 & 0.015 & 0.753 & 0.267 & 0.845 & 0.027 & 0.105 \\
\hline ATP5J & 0.132 & 0.258 & -0.497 & 1.145 & 0.552 & 1.273 & 0.033 & 0.121 \\
\hline ATPG & 0.092 & -0.035 & -0.062 & 1.111 & 0.501 & 0.440 & 0.035 & 0.125 \\
\hline
\end{tabular}




\begin{tabular}{|l|l|l|l|l|l|l|l|l|}
\hline ATPD & -0.187 & 0.132 & 0.037 & 0.610 & 0.093 & 0.304 & 0.126 & 0.287 \\
\hline ADT1 & -0.090 & 0.269 & -0.226 & 2.030 & 1.773 & 1.979 & 0.000 & 0.013 \\
\hline ADT2 & -0.431 & 0.656 & -0.552 & 0.046 & 0.829 & 1.007 & 0.203 & 0.400 \\
\hline
\end{tabular}

Table 1. Proteins related to the ETC detected in $\mathrm{CD}^{+}{ }^{+} \mathrm{T}$ cells isolated from old mice after mitotransfer and in non-manipulated $\mathrm{CD}^{+} \mathrm{T}$ cells from old mice. CD4+ $\mathrm{T}$ cells from young and old mice, and from old mice after mito-transfer were cultured for $4 \mathrm{~h}$ prior to processing for mass spectrometry analysis. Data expressed as median protein Log2 fold change of CD4 ${ }^{+} \mathrm{T}$ cells from old mice, from 3 individual old mice (paired experiment) 


\begin{tabular}{|c|c|c|c|c|c|c|c|c|}
\hline Protein & 01 & 02 & 03 & OM1 & OM2 & OM3 & P. value & FDR \\
\hline SODM & -0.168 & 0.241 & -0.107 & 0.608 & 0.369 & 0.575 & 0.023 & 0.096 \\
\hline GSHR & 0.253 & -0.088 & -0.206 & -0.553 & -1.164 & -1.170 & 0.018 & 0.084 \\
\hline GLO2 & 0.222 & 0.079 & -0.363 & 0.061 & -0.433 & 0.066 & 0.754 & 1.000 \\
\hline PRDX3 & 0.157 & -0.115 & -0.057 & 0.722 & 0.453 & 0.618 & 0.006 & 0.046 \\
\hline TRXR2 & -0.114 & 0.237 & -0.155 & 0.010 & -0.085 & 0.133 & 0.839 & 1.000 \\
\hline SODC & -0.157 & 0.077 & 0.068 & -1.016 & -1.222 & -1.101 & 0.000 & 0.013 \\
\hline CCS & -0.153 & -0.067 & 0.197 & -0.802 & -1.300 & -1.115 & 0.004 & 0.036 \\
\hline CATA & 0.192 & 0.014 & -0.238 & 1.054 & 0.418 & 0.508 & 0.046 & 0.148 \\
\hline GPX8 & -0.156 & 0.384 & -0.327 & 5.763 & 5.289 & 5.780 & 0.000 & 0.007 \\
\hline GPX7 & 0.375 & -0.901 & 0.224 & 5.580 & 5.130 & 5.561 & 0.000 & 0.012 \\
\hline LGUL & -0.244 & 0.190 & 0.021 & -1.451 & -1.668 & -1.753 & 0.000 & 0.014 \\
\hline GSTP1 & -0.131 & 0.008 & 0.113 & -1.044 & -1.373 & -0.801 & 0.004 & 0.036 \\
\hline MGST1 & 0.642 & -0.357 & -0.602 & 1.222 & 1.146 & 2.052 & 0.030 & 0.113 \\
\hline ESTD & 0.054 & 0.101 & -0.169 & -0.158 & -0.703 & -0.374 & 0.086 & 0.222 \\
\hline GSTM2 & 0.398 & -3.807 & 0.688 & 2.041 & 1.328 & 2.835 & 0.121 & 0.279 \\
\hline GPX1 & 0.354 & -0.103 & -0.338 & -0.131 & -0.907 & -0.980 & 0.131 & 0.294 \\
\hline GSTM1 & 0.771 & -0.484 & -0.789 & -0.465 & -1.246 & -0.866 & 0.260 & 0.476 \\
\hline GSTK1 & 0.074 & 0.064 & -0.148 & 0.441 & -0.507 & -0.314 & 0.701 & 0.977 \\
\hline HMOX2 & -0.054 & 0.135 & -0.092 & 0.198 & 0.014 & 0.374 & 0.188 & 0.378 \\
\hline HMOX1 & 0.365 & 0.159 & -0.748 & 0.009 & -0.762 & -0.675 & 0.394 & 0.643 \\
\hline TMX2 & 0.156 & 0.034 & -0.215 & 0.862 & 0.704 & 0.901 & 0.003 & 0.030 \\
\hline TXND5 & 0.063 & 0.148 & -0.239 & 0.932 & 0.705 & 0.934 & 0.003 & 0.033 \\
\hline TXNL1 & 0.074 & 0.114 & -0.209 & -0.895 & -1.304 & -0.747 & 0.008 & 0.051 \\
\hline TXD17 & -0.232 & 0.273 & -0.089 & -1.587 & -1.845 & -2.923 & 0.008 & 0.055 \\
\hline THIO & 0.234 & -0.327 & 0.038 & -0.876 & -2.020 & -1.773 & 0.016 & 0.079 \\
\hline TRXR1 & 0.005 & -0.110 & 0.098 & -0.404 & -1.261 & -1.318 & 0.030 & 0.114 \\
\hline TXD12 & 0.181 & -0.240 & 0.028 & 0.513 & 0.548 & 1.109 & 0.033 & 0.119 \\
\hline TMX1 & -0.076 & 0.240 & -0.200 & 0.781 & 0.480 & 0.316 & 0.047 & 0.149 \\
\hline TMX4 & 0.083 & -0.103 & 0.014 & 0.126 & -0.104 & 0.182 & 0.533 & 0.800 \\
\hline TXD15 & 0.610 & 0.193 & -1.596 & 0.057 & -1.043 & 0.535 & 0.896 & 1.000 \\
\hline
\end{tabular}

Table 2. Antioxidant proteins detected in $\mathrm{CD}^{+} \mathrm{T}$ cells isolated from old mice after mito-transfer and in non-manipulated $\mathrm{CD} 4^{+} \mathrm{T}$ cells from old mice. $\mathrm{CD}^{+} \mathrm{T}$ cells from young and old mice, and from old mice after mito-transfer were cultured for $4 \mathrm{~h}$ prior to processing for mass spectrometry analysis. Data expressed as median protein Log2 fold change of CD4+ $T$ cells from old mice, from 3 individual old mice (paired experiment) 